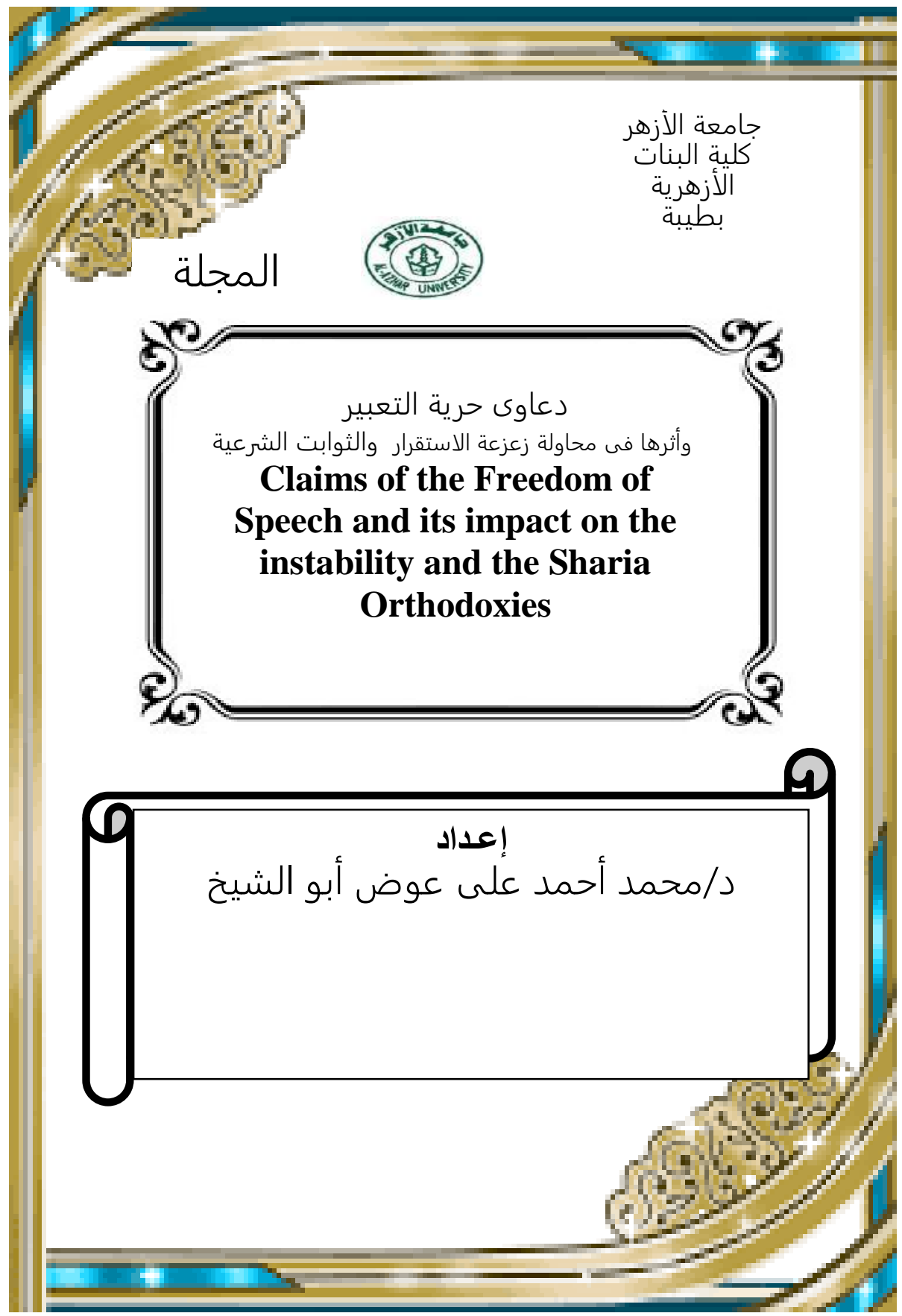




\section{A Synopsis}

This study tackles the freedom of opinion - a controversial issue with which society was obssessed. It led to a messy atmopsphere, inaccuracies and skeptical attitudes about the main pillars of Sharite. These opinions should not have been pronounced by a Muslim or non-Muslim.

The paper will approach the allegations of freedom of opinion and how they terribly shake the main pillars of islam. The descriptive and analytic approach in data collecting. 
دعاوى حرية التعبير وأثرها فى زعزعة الاستقرار والثوابت

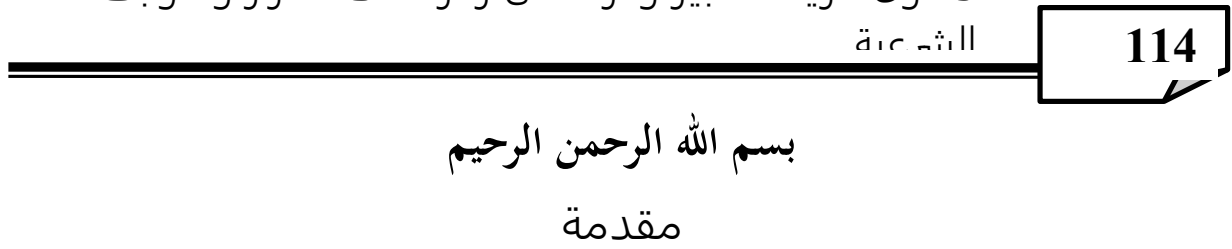

إن الحمد لله نحمده ونستعينه ونستهديه ونستغفره، ونعوذ بالله من شرور

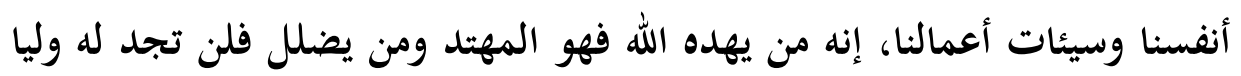

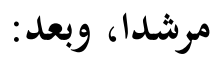
قال تعالى: \}يا أيها الذين آمنوا اتقوا الله حق تقاته ولا تموتن إلا وأنتم مسلمون\{ [آل عمران: 102].

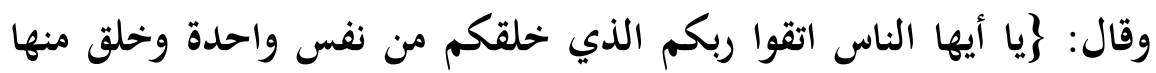
زوجها وبث منهما رجالا كثيرا ونساء واتقوا الله الذي تساءلون به والأرحام إن الله كان عليكم رقيبا\{ [النساء: 1. وقال: \}يا أيها الذين آمنوا اتقوا الله وقولوا قولا سديدا يصلح لكم أعمالكم ويغفر لكم ذنوبكم ومن يطع الله ورسوله فقد فاز فوزا عظيما؛ [الأحزاب: 70،

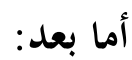

فإن أصدق الحديث كتاب الله، وخير الهدي هدي محمد صلى الله عليه

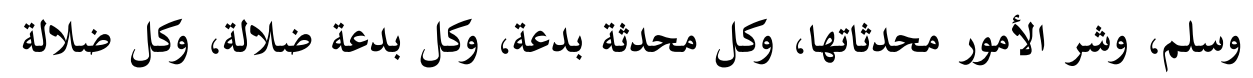
في النار.

جاءت الشريعة الإسلامية بضوابط لتنظيم شئون حياة الناس فيما بينهم،

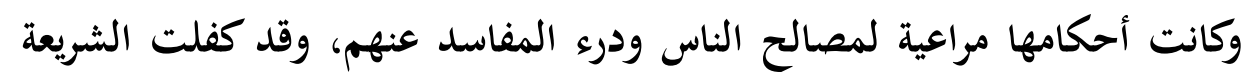
بأحكامها الحرية بكافة ألوانها وأشكالها، شريطة أن تكون في نطاق ودرأ شرعي مستند 
دعاوى حرية التعبير وأثرها فى زعزعة الاستقرار والثوابت

إلى أدلة شرعية.

وسوف نلقي الضوء في هذا البحث على موضوع شائك، كثر الحديث عنه والتمسك بله، وأن أمور الحياة وشئونها في نظر من تمسكوا بهذا- والذي يعتبرونه مبدأ من مبادئ الحياة الإنسانية الواجب التطبيق- تقوم عليه، فكل حركة وسكنة في الحياة تنطاع لهذا الموضوع. هذا الموضوع هو حرية التعبير عن الرأي، الذي غالى فيه الكثير حتى أصبح آفة أصابت المجتمعات، فأفسدت أكثر مما أصلحت؛ فنجد بلايا قد ظهرت ومخالفات قد بدت تحت هذا الشعار، حتى وصلت تلك البلايا والمخالفات إلى الطعن في الثوابت الثرعية التي لا يملك أحد أن يطعن فيها بأي وجه كان، ولو كان هذا الطاعن من غير ملة الإسلام. ونحن في هذا البحث سنتناول الحديث عن هذا الموضوع تحت عنوان \دعاوى حرية التعبير وأثرها في محاولة زعزعة الثوابت الثرعيةه، وسوف نتبع في جمع مادة هذا البحث المنهج الوصفي التحليلي الاستقرائي، وذلك في عدة مباحث هي: المبحث الأول: تعريف حرية التعبير والثوابت الشرعية لغة واصطلاحا. المبحث الثاني: ضوابط حرية التعبير في الثريعة الإسلامية. المبحث الثالث: أثر الضروريات المقاصدية الخمسة في حرية التعبير. المبحث الرابع: أثر حرية التعبير في محاولة زعزعة الثوابت الثرعية. ثم أتبعت تلك المباحث بخاتمة بينت فيها أهم ما توصلت إليه خلال بحثي

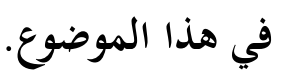
وصلى الله على محمد وآله وصحبه وسلم تسليما كثيرا. المبحث الأول 
دعاوى حرية التعبير وأثرها فى زعزعة الاستقرار والثوابت

تعريف حرية التعبير والثوابت الشرعية لغة واصطلاحا

$$
\begin{aligned}
& \text { أولا: تعريف حرية التعبير: } \\
& \text { أ- حرية التعبير لغة: }
\end{aligned}
$$

حرية التعبير في اللغة مركب لفظي إضافي يتكون من لفظتين: لفظة حرية، ولفظة التعبير، ولكل منهما في المعاجم العربية معنى يختلف عن الأخرى، كما أن المركب اللفظي نفسه له معنى، وبيان ذلك كله فيما يلي:

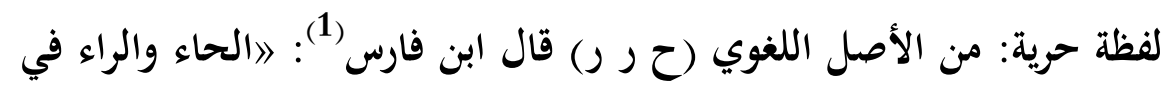
المضاعف له أصلان: فالأول ما خالف العبودية وبرئ من العيب والنقص، يقال: هو حر بيّن الحرورية والحرية، ويقال: طين حر. لا رمل فيه... والثاني خلاف البرد يقال: هذا يوم ذو حر ويوم حار《) (2).

(1) هو: أحمد بن فارس بن زكريا بن محمد بن حبيب، أبو الحسين القزويني الرازي، نزيل

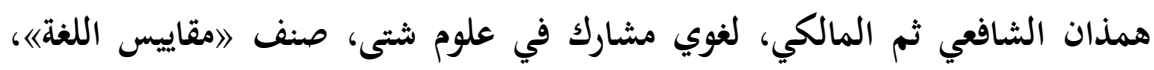
و 》مجمل اللغة) وغيرهما، توفي سنة (395ه). ينظر: نزهة الألباء في طبقات الأدباء،

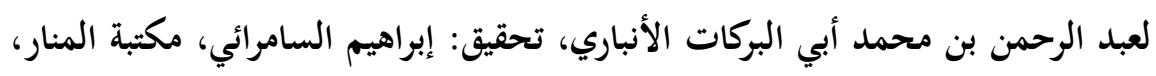
الأردن، الطبعة الثالثة، سنة 1405هـ- 1985م، ص 235، ومعجم الأدباء المسمى

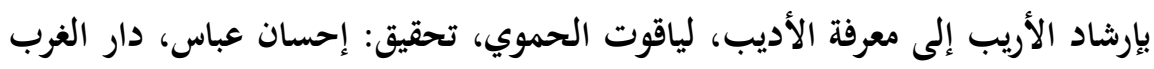
الإسلامي، بيروت، الطبعة الأولى، سنة 1414هـ- 1993م، 11 / 410.

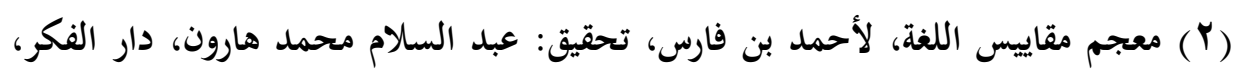

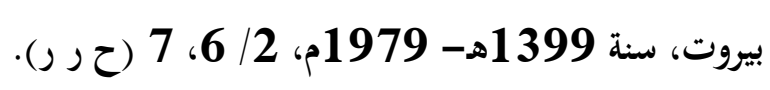


دعاوى حرية التعبير وأثرها فى زعزعة الاستقرار والثوابت

والحر بالضم من الرجال خلاف العبد؛ لأنه خلص من الرق وجمعه أحرار(1). فالحرية إذن ضد الرق، يقال: إنه لحر بيِّن الحرية(2).

وللحرية في اللغة معان أخرى غير هذا منها أنها بمعنى التعب والعطش ووسط

الدار وضد البرد وغير ذلك من المعاني (3).

والمعنى الأول هو المراد في بحثنا هذا لذلك عولنا عليها كثيرا.

أما لفظة التعبير فهي من مصدر على وزن 》اتفعيل《 من الفعل الرباعي مشدد العين 》عبَّر ، والذي أصله الجذر اللغوي (ع ب ر) قال ابن فارس: 》العين والباء والراء أصل صحيح واحد يدل على النفوذ والمضي في الثيء《(4). والتعبير في اللغة يأتي بأكثر من معنى فيأتي بمعنى التفسير والإخبار بما يؤول، كتعبير الؤيا، وتأتي أيضا بمعنى الإعراب والبيان فيقال: عبر عما في نفسه

(1) ينظر: المصباح المنير في غريب الشرح الكبير، لأحمد بن محمد بن علي الفيومي،

$$
\text { المكتبة العلمية، بيروت، } 128 \text { / } 128 \text { (ح ر ر). }
$$

(Y) المعجم الكبير، أعد هذا الجزء: عبد الصمد علي محروس وإقبال زكي سليمان، ومراجعة الأستاذ الدكتور محمود علي مكي، مجمع اللغة العربية، القاهرة، الطبعة الأولى، سنة

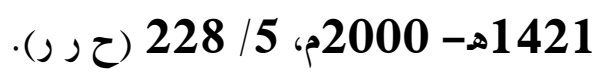

(r ينظر تلك المعاني في مادة (ح ر ر) في: لسان العرب، لمحمد بن مكرم ابن منظور، دار

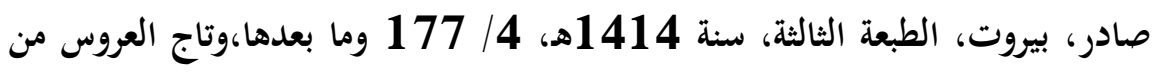
جواهر القاموس، لمحمد بن محمد المرتضى الزبيدي، دار الهداية، 10/ 573 وما

$$
\text { (ع بعدا. }
$$


تعبيرا أبي بيَّن وأعرب. ويأتي أيضا بمعنى العبور والمرور يقال: عبر النهر أو

$$
\text { الطريق. ويأتي بمعنى الوزن والتعجب وغير ذلك(1). }
$$

أما المركب اللفظي حرية التعبير فقد عرفها الدكتور أحمد مختار عمر أحد

اللغويين بأنه: القدرة على التصرف بملء الإرادة والاختيار (2. ب- حرية التعبير اصطلاحا:

حرية التعبير مصطلح حديث لم أقف عليه نصا في كتب التشريع الإسلامي القديمة، ولكن تناول العلماء حديثا هذا المصطلح وعرفوه بما يلي: هو تمتع الإنسان بكامل حريته في الجهر بالحق وإسداء النصيحة في كل أمور الدين والدنيا، فيما يحقق نفع المسلمين ويصون مصالح كل من الفرد والمجتمع ويحفظ النظام العام، وذلك في إطار الأمر بالمعروف والنهي عن

(1) ينظر تلك المعاني وغيرها في مادة (ع ب ر) في: الصحاح تاج اللغة وصحاح العربية، لأبي نصر إسماعيل بن حماد الجوهري، تحقيق: أحمد عبد الغفور عطار، دار العلم للملايين، بيروت، الطبعة الرابعة، سنة 1407هـ إسمادئ 1987م، والمصباح المنير 2/ 389، وتاج العروس 12 / 501 وما بعدها.

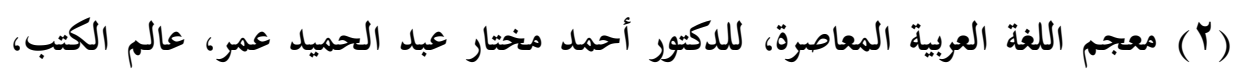
الطبعة الأولى، سنة 1429هـ- 2008م، 11 / 470. 
دعاوى حرية التعبير وأثرها فى زعزعة الاستقرار والثوابت

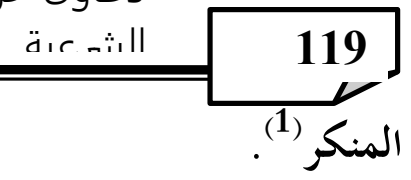

وقيل في تعريفه أيضا: إنه عدم القيود أو المحددات التي تعوق الإنسان عن

ممارسة حقه في التعبير عما يدور في نفسه من رأي أو فكر (2).

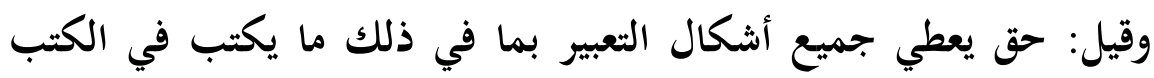

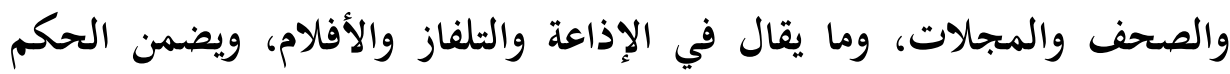
الإسلامي للناس حق التعبير عن آرائهم بحرية في إطار الشورى؛ لأن الشورى

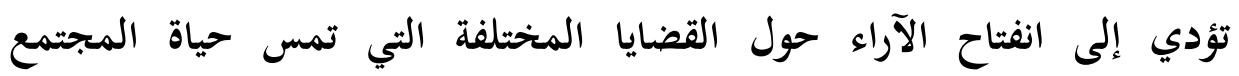
الإسلامي (3).

ثانيا: تعريف الثوابت الشرعية: الئا

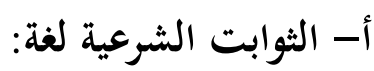

الثوابت الشرعية مركب لفظي يتكون من لفظتين: لفظة الثوابت، ولفظة

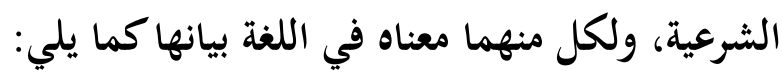

(1) حقوق الإنسان في الإسلام والرد على الثبهات المثارة حولها، لسليمان بن عبد الرحمن

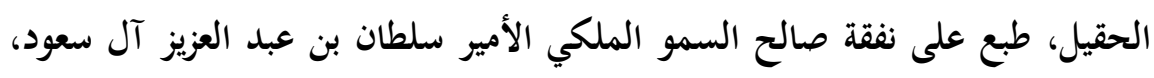

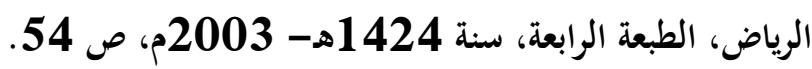

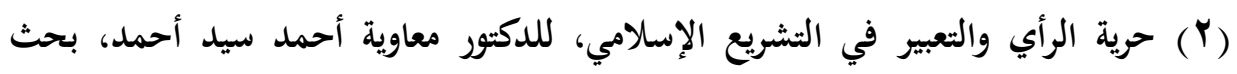

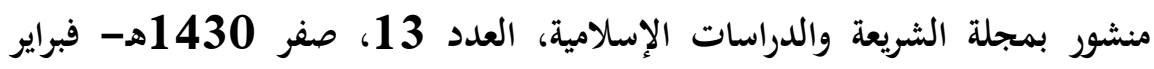

2009م، ص 61. (ץ) الموسوعة العربية العالمية، مؤسسة أعمال الموسوعة للنشر والثوزيع، الرياض، الطبعة

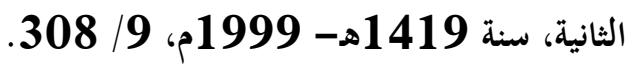


دعاوى حرية التعبير وأثرها فى زعزعة الاستقرار والثوابت

الثوابت جمع ثابت، اسم فاعل من الفعل الثلاثي ثبت، قال ابن فارس: \الثاء والباء والتاء كلمة واحدة وهي دوام الثيء، يقال: ثبت ثباتا وثبوتا، ورجل ثبت

وثبيته (1)

وثبت الشيء يثبت ثبوتا دام واستقر فهو ثابت وبه سمي، وثبت الأمر صح،

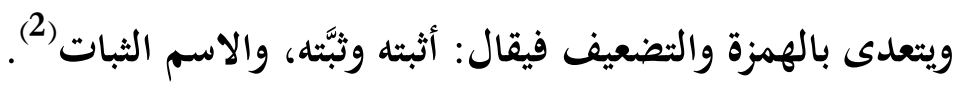
أما لفظة الشرعية فهي نسبة إلى الشرع وهو مصدر من الفعل الثلاثي شرع، قال ابن فارس: 》الشين والراء والعين أصل واحد وهو شيء يفتح في امتداد يكون فيه، من ذلك الشريعة... واشتق من ذلك الشرعة في الدين والشريعةه (3). ويعبر بالشريعة والشرائع عما شرع الله للعباد من أمر الدين وأمرهم بالتمسك به من الصلاة والصوم والحج وشبهه (4). ويمكن استخلاص تعريفا لغويا للتركيب اللفظي ثوابت شرعية من خلال ما نقله اللغويون في معاجمهم بأنه ما دام واستقر عليه الشرع الذي هو من عند الله.

$$
\text { ب- الثوابت الشرعية اصطلاحا: }
$$

مصطلح الثوابت الثرعية لم يكن مستخدما في التراث الفقهي القديم، بل تعارف عليه العلماء والفقهاء في العصور الحديثة وعرفوه بما يلي:

$$
\begin{aligned}
& \text { (1) مقاييس اللغة 1/ } 399 \text { (ث ب ت). } \\
& \text { (Y) المصباح المنير 1/ / } 80 \text { (ث ب ت ت). } \\
& \text { (r) مقاييس اللغة 3/ } 262 \text { (ش ر ع). }
\end{aligned}
$$

(\&) العين، للخليل بن أحمد الفراهيدي، تحقيق: الدكتور مهدي المخزومي والدكتور إبراهيم

$$
\text { السامرائي، دار ومكتبة الهلال، 1/ } 253 \text { (ش ر ع). }
$$


دعاوى حرية التعبير وأثرها فى زعزعة الاستقرار والثوابت

عرفه الدكتور محمد الزحيلي بقوله: اوالثوابت في الشريعة هي الأحكام

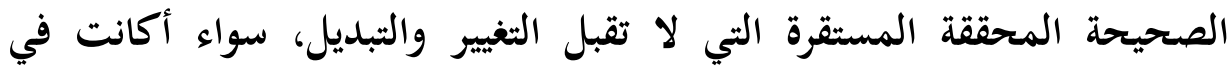

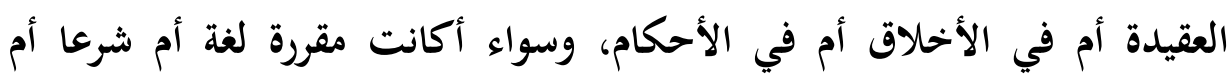
عقلان 11 (1).

وعرفه غيره بقوله: 》الثوابت هي الأحكام التي دلت عليها أدلة قطعية الثبوت والدلالة أو الإجماع الصحيح، وعريت عن بناء على متغير، ويعبر الفقهاء عنها بقولهم: لا مساغ للاجتهاد فيه. وبقولهم: الأحكام القطعية. وبعضهم سماه وعاه بأصول الدين《) (2).

(1) الثوابت والمتغيرات في الشريعة الإسلامية، للأستاذ الدكتور محمد مصطفى الزحيلي، الزئل

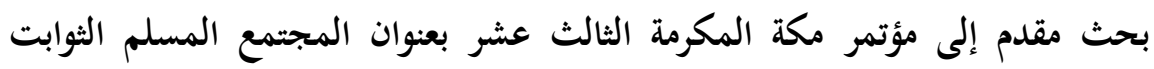

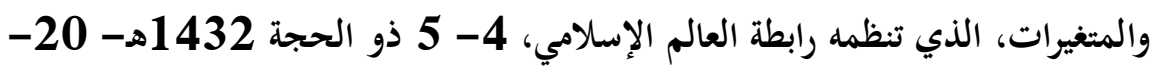

$$
21 \text { أكتوبر 2012م، ص } 7 .
$$

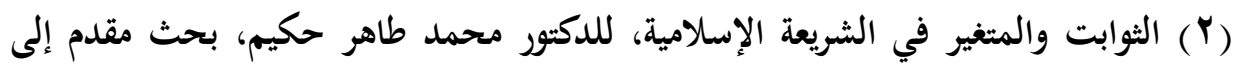

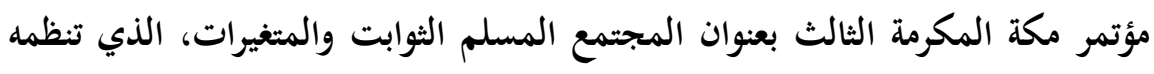

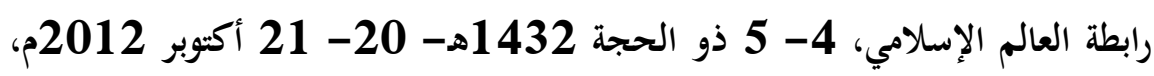

ص 7. 
دعاوى حرية التعبير وأثرها فى زعزعة الاستقرار والثوابت

\section{المبحث الثاني}

ضوابط حرية التعبير في الشريعة الإسلامية

كفل الإسلام للناس جميعا حرية التعبير وأقر ذلك حتى في اعتناق الإسلام

نفسه فقال سبحانه وتعالى: \}لا إكراه في الدين\{ [البقرة: 256]. وقوله:

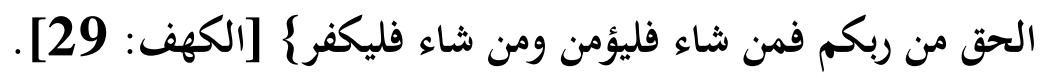

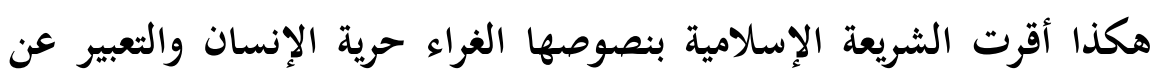

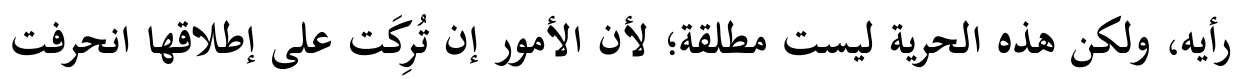

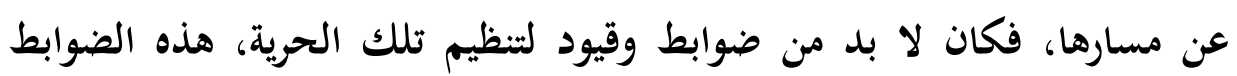

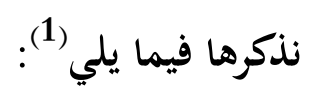

الضابط الأول: أن يكون الرأي موافقا لأحكام الشريعة مقيدا بنصوصها:

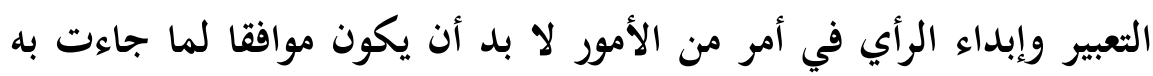

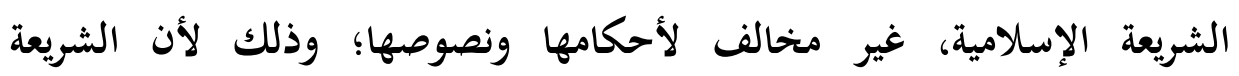

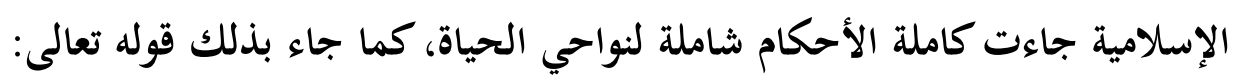
\}اليوم أكملت لكم دينكم وأتممت عليكم نعمتي ورضيت لكم الإسلام دينأ

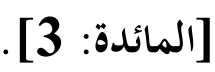

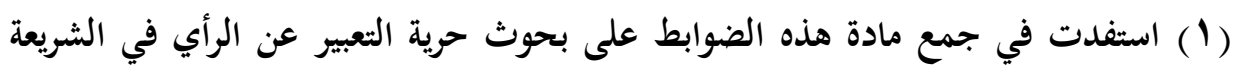

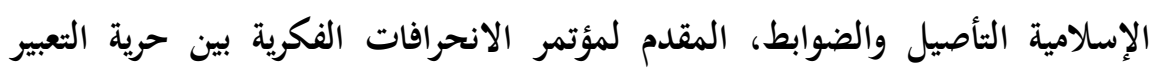

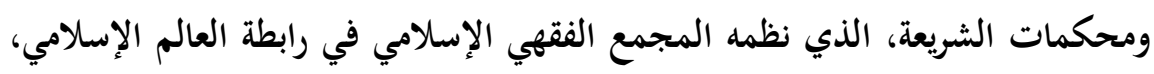

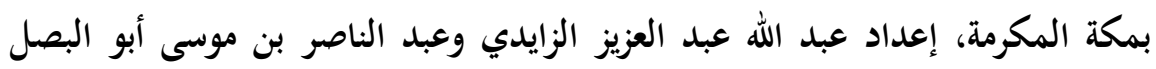

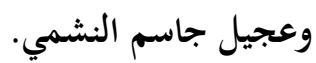


كما أن نصوص القرآن والسنة تتسم بأنها هادية للحق والصواب مبعدة عن

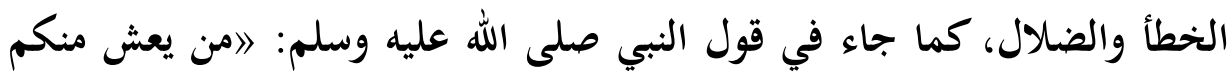

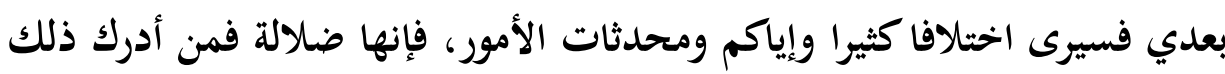
منكم فعليكم بسنتي وسنة الخلفاء الراشدين المهديين عضوا عليها بالنواجذه (1).

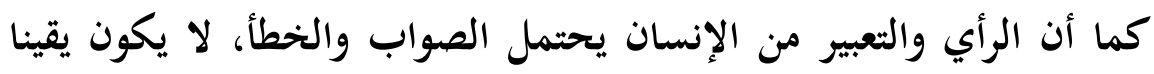
قطعا؛ فهو قائم على الظن والاجتهاد، ولذا قال عمر بن الخطاب رضي الله عنه: 》الرأي من رسول الله صلى الله عليه وسلم كان مصيبا؛ لأن الله تعالى كان يريه إياه، وهو منا الظن والنكليف《)

ومن هذا المنطلق لا بد أن يكون الرأي صادرا من شخص ملم من بشيء من

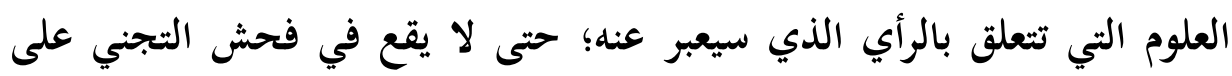

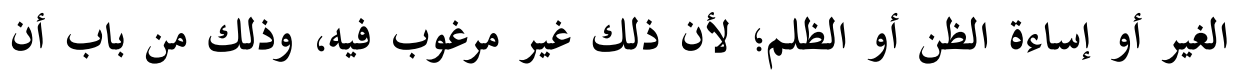

(1) أخرجه أبو داود سليمان بن الأشعث السجستاني في سننه، تحقيق: محمد محيي الدين

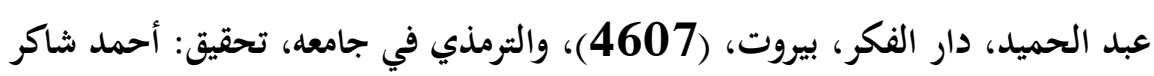

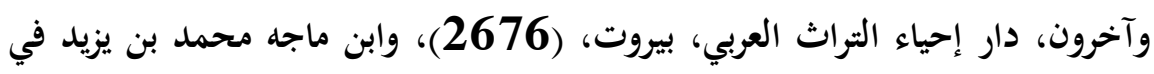

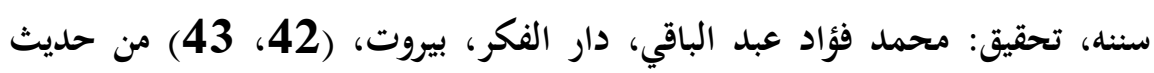

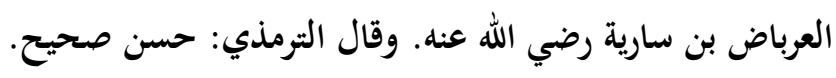

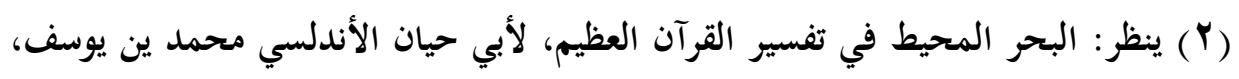

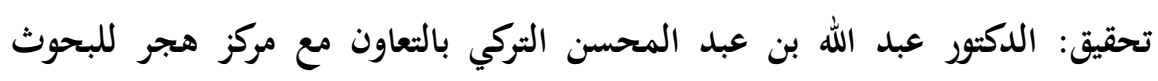

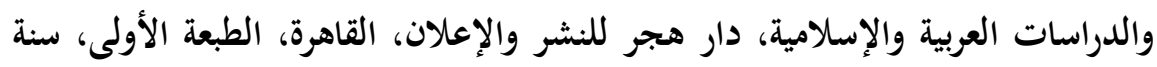

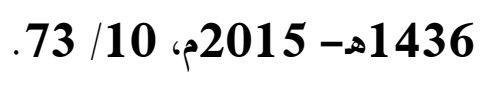

مجلة كلية البنات الأزهرية بطيبة الجديدة ـ بالأقصر

$$
\text { العدد الثانى 2018م }
$$


الاجتهاد بابه مفتوح في كل عصر ومصر إذا توافرت فيه شروط الاجتهاد سواء

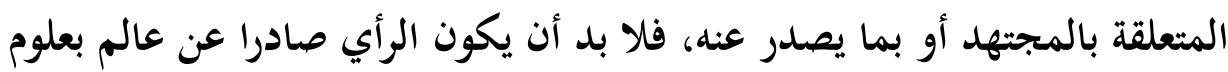
الشريعة وفقهها وأصولها حتى لا يخالف نصا صريحا من كتاب أو سنة رسوله صلى

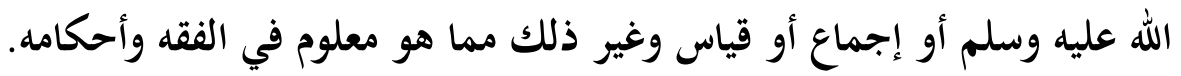

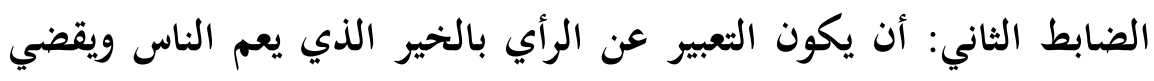

حوائجهم: - (1)

إذا لم يكن التعبير بالرأي يحمل الخير وقضاء حوائج الناس فهو يفسد أكثر

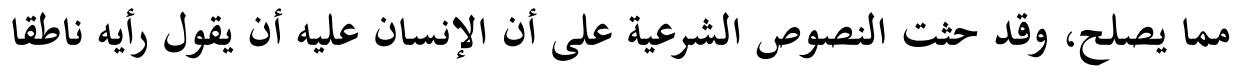

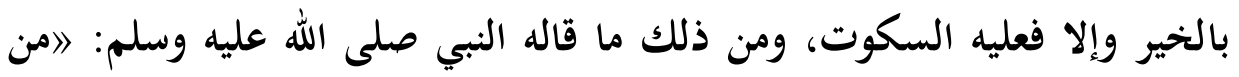

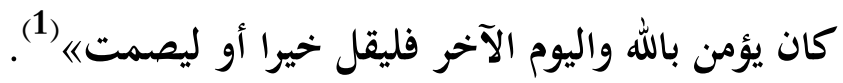
ومن هذا المنطلق على الإنسان ألا يعبر عن رأيه بغيبة أو نميمة أو سب أو لو لإِ قذف أو شهادة زور، بل ينطق بكل خير يراه.

الضابط الثالث: ألا يكون تعبيره يحمل إساءة إلى شخص أو أشخاص تمس لرس حياتهم أو أعراضهم أو سمعتهم أو مكانتهم:

(1) أخرجه محمد بن إسماعيل البخاري في صحيحه المسمى بالجامع الصحيح المختصر

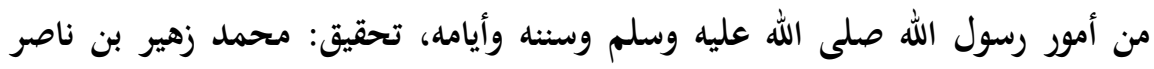
الناصر، دار طوق النجاة، الطبعة الأولى، سنة 1422هـ، (6018، 6136، 6138، 6475)، ومسلم بن الحجاج في صحيحه المسمى المسند الصحيح

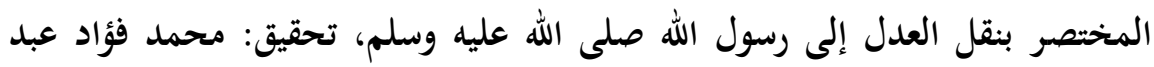
الباقي، دار إحياء التراث العربي، بيروت، (47) من حديث أبي هريرة رضي الله عنه. 
دعاوى حرية التعبير وأثرها فى زعزعة الاستقرار والثوابت

الحفاظ على حياة الغير وعرضه وسمعته ومكانته الأدبية أمر محمود ندب

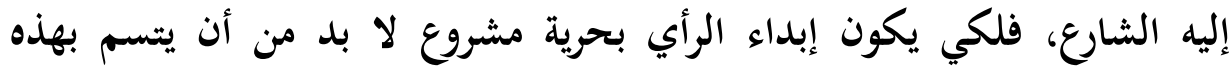
الأمور، فقد قال النبي صلى الله عليه وسلم: السباب المسلم فسوق وقتاله كفر «)

قال النووي(2) في شرح هذا الحديث: 》معنى الحديث فسب المسلم بغير

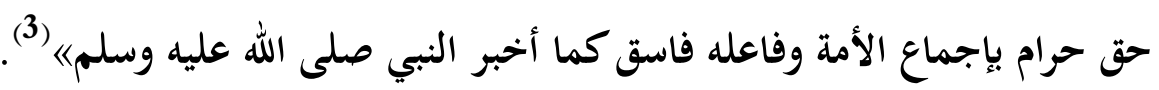

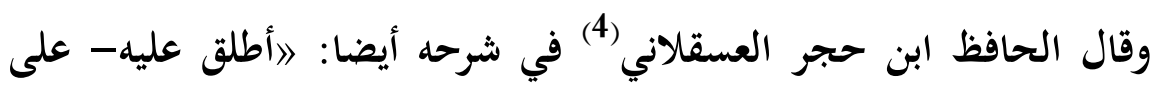

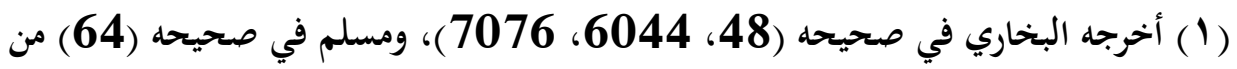
حديث عبد الله بن مسعود رضي الله عنه.

(Y) هو : يحيى بن شرف بن مري بن حسن، محيي الدين أبو زكريا النووي، كان إماما بارعا

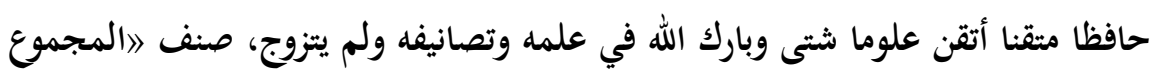

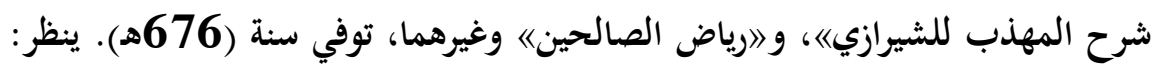

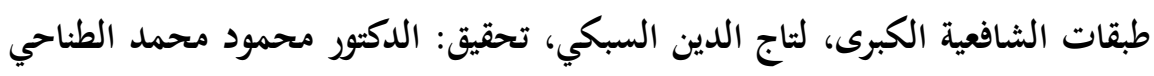

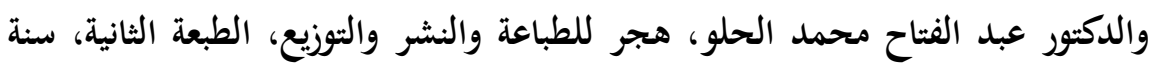

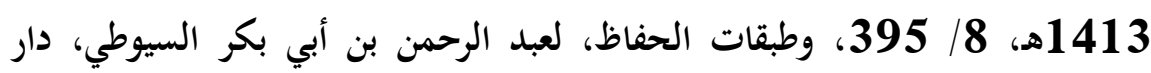

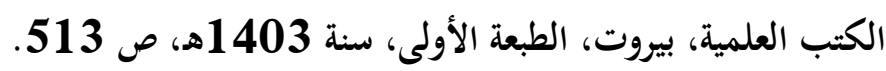

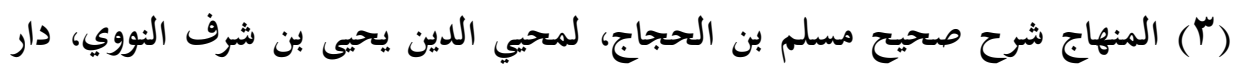

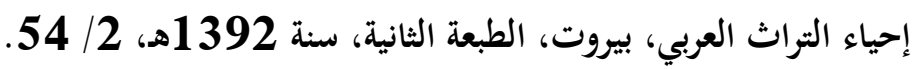

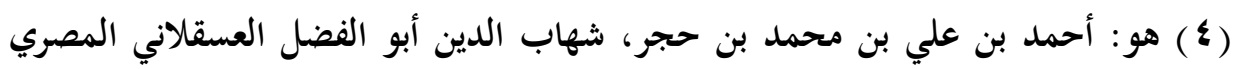

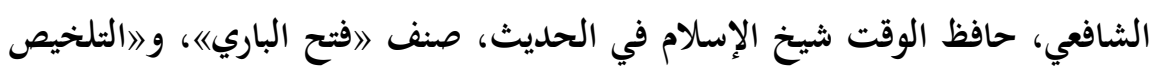

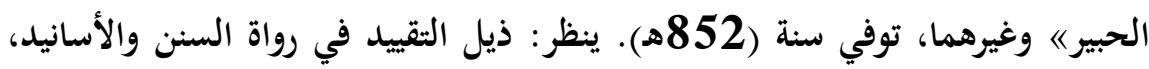


دعاوى حرية التعبير وأثرها فى زعزعة الاستقرار والثوابت

قتال المؤمن أنه كفر - مبالغة في التحذير من ذلك لينزجر السامع عن الإقدام

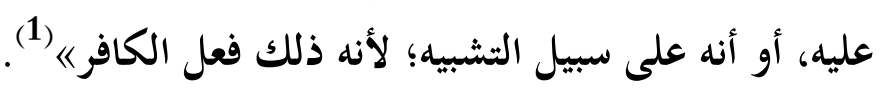

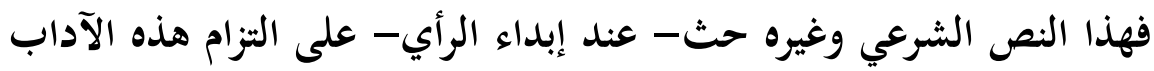
الشرعية المشار إليها حتى يكون هذا الرأي مقبولا يُعمَل به.

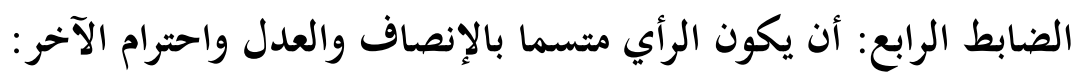

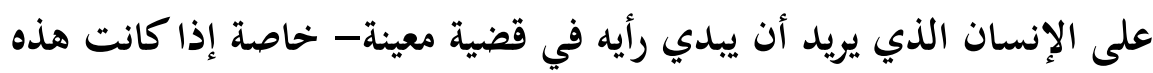

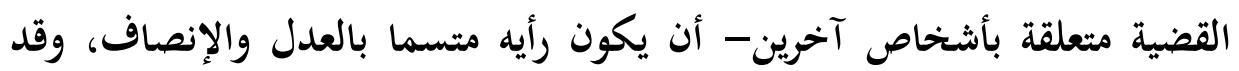

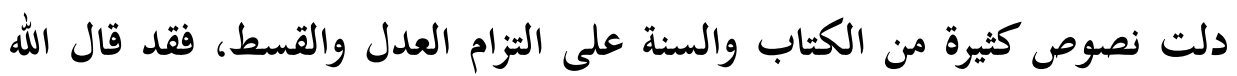
سبحانه وتعالى: (وأقسطوا إن الله يحب المقسطين\{ [الحجرات: 9 9.

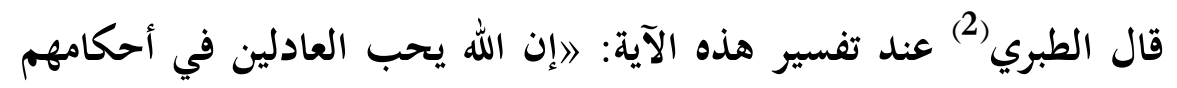

لمحمد بن أحمد الفاسي، تحقيق: كمال يوسف الحوت، دار الكتب العلمية، بيروت،

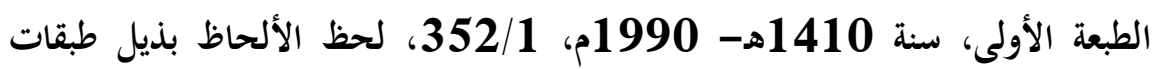
الحفاظ، لمحمد بن محمد الأصفوني، دار الكتب العلمية، بيروت، الطبعة الأولى، سنة

\section{1411/1998 1980}

(1) فتح الباري شرح صحيح البخاري، لأحمد بن علي بن حجر العسقلاني، رقم كتبه وأبوابه

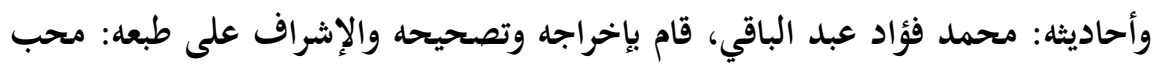
الدين الخطيب، دار المعرفة، بيروت، سنة 1379هـ 13 / 27. (Y) هو: محمد بن جرير بن يزيد بن كثير الطبري أبو جعفر، الإمام العلم المجتهد عالم

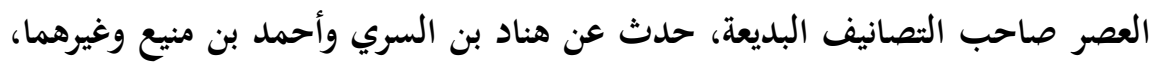
وحدث عنه أحمد بن كامل القاضي ومخلد بن جعفر وغيرهما، صنف الأخبار الرسل 
دعاوى حرية التعبير وأثرها فى زعزعة الاستقرار والثوابت

القاضين بين خلقه بالقسط» (1).

الضابط الخامس: أن يكون الرأي من منطلق المحافظة على أمن المجتمع

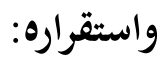

من الأسس الهامة التي أكد عليها الإسلام في نصوصه الحفاظ على أمن

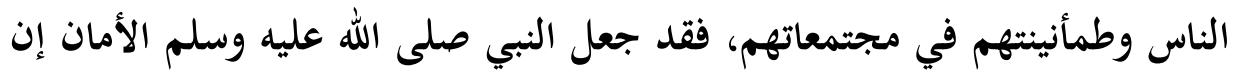

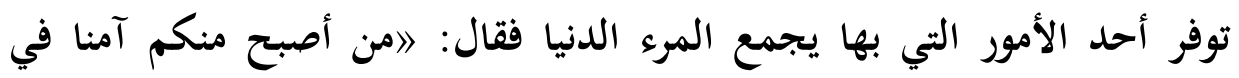

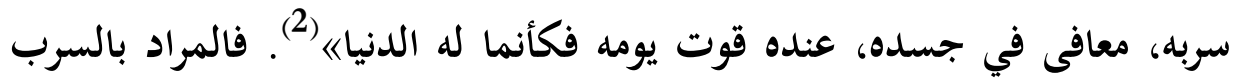

والملوك《، و إختلاف الفقهاء《، وغيرها، توفي سنة (310 هـ). ينظر : تاريخ بغداد،

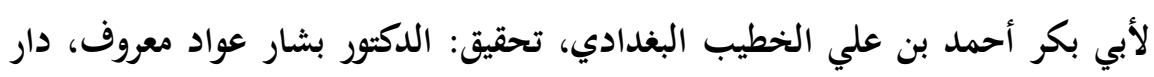

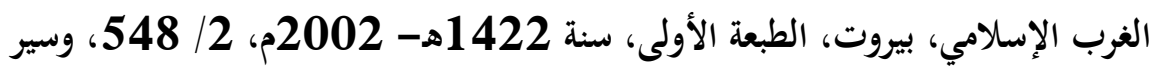

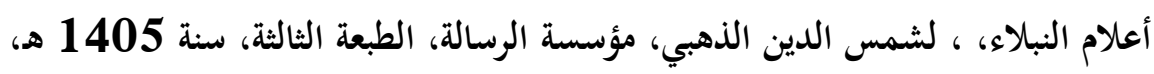

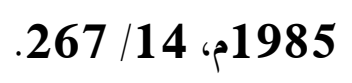

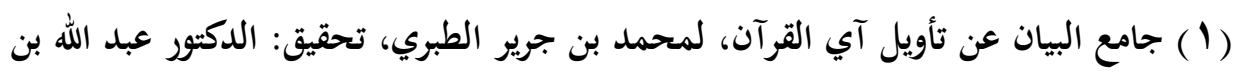

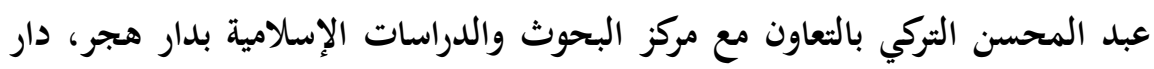

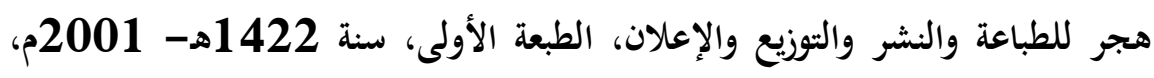
$.363 / 21$

(Y) أخرجه الترمذي في جامعه (2346) من حديث عبد علد الله بن محضن الخطمي رضي الله عنه. وقال: حديث حسن غريب. 
هنا القوم والأهل والأولاد وقيل: الطرق والسكك(1). وكلا المعنيين ينطبقان على المجتمع الذي نعيش فيه.

ولم يقف الأمر عند هذا فحسب ولكن حرم النبي صلى الله عليه وسلم ترويع

المسلمين بأي وسيلة فقال: 》الا يحل لمسلم أن يروع مسلما《) (2).

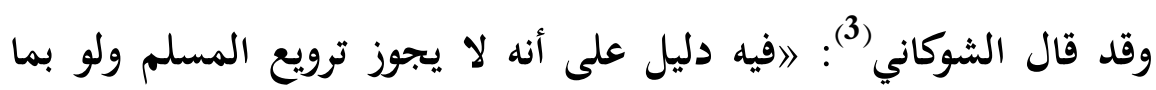

(1) ينظر: الميسر في شرح مصابيح السنة، لفضل الله بن حسن بن حسين بن يوسف الهف

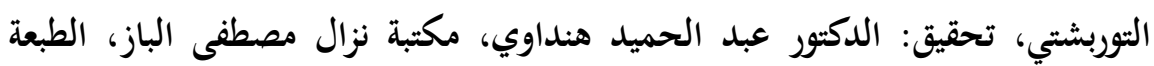

الثانية، سنة 1429هـ- 2008م، 1106 / 1106.

(Y) أخرجه أبو داود في سننه (5004) من حديث عبد الرحمن بن أبي ليلى عن نفر من

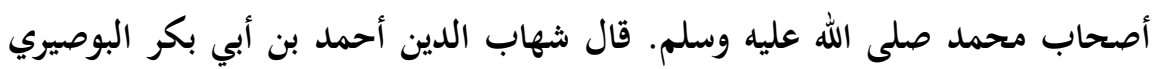

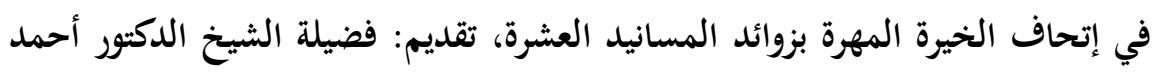

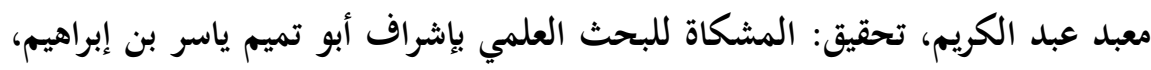

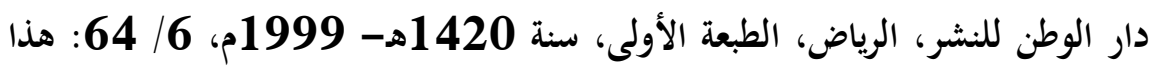

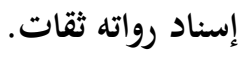

(זّ) هو: محمد بن علي بن محمد الشوكاني، فقيه مجتهل من كبار علماء صنعاء اليمن،

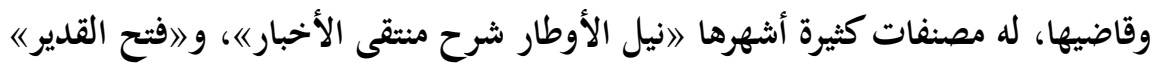
في التفسير، ولإرشاد الفحول《 في الأصول، وغيرها، توفي سنة (1250 هـ). ينظر:

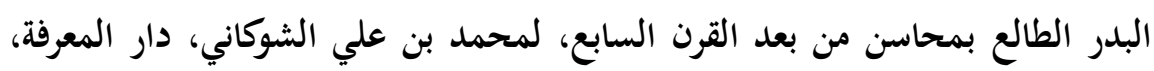

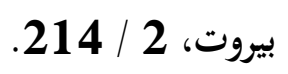


دعاوى حرية التعبير وأثرها فى زعزعة الاستقرار والثوابت

$$
\text { är-ثll }
$$

صورته صورة المزح《)

وبناء على ذلك على الإنسان أن يراعي تجنب التسبب في فزع الآخرين وهلعهم بأي وسيلة ممكنة، ومن هنا فعلى من أراد التعبير برأيه في أمر من الأمور لا بد له أن يراعي ذلك، بل يكون حريصا عليه كل الحرص.

وبناء على ذلك فقد أوصى مجلس مجمع الفقه الإسلامي الدولي المنبثق عن ئن منظمة المؤتمر الإسلامي أن من ضوابط حرية التعبير أن تؤخذ بالاعتبار المآلات والآثار التي قد تنجم عن التعبير عن الرأي، وذلك مراعاة لقاعدة التوازن بين المصالح والمفاسد، وما يغلب منها على الآخر (2). الضابط السادس: على الإنسان عند إبداء رأيه أن يفرق بين النقد والتشهير:

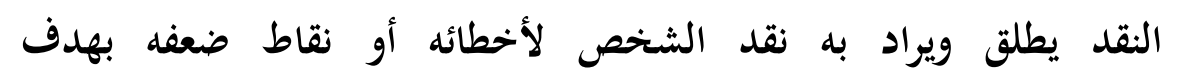

(1) نيل الأوطار، لمحمد بن علي بن محمد بن عبد الله الشوكاني اليمني، تحقيق: عصام الدين الصبابطي، دار الحديث، مصر، الطبعة الأولى، سنة 1413هـ

(Y) ينظر: بحث حرية التعبير عن الرأي في الشريعة الإسلامية التأصيل والضوابط، المقدم

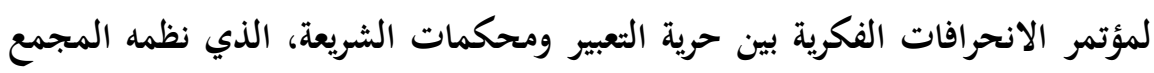

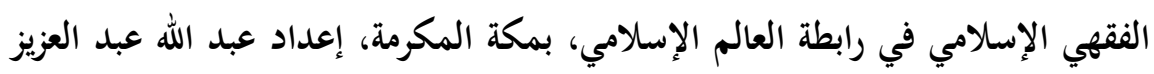

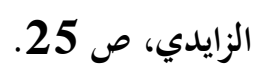


دعاوى حرية التعبير وأثرها فى زعزعة الاستقرار والثوابت

تحسينها (1)، وأما التشهير فيراد به إشاعة السوء عن إنسان بين الناس(2).

مفهوم النقد المذكور هو المراد هنا؛ حيث إنه يتحتم على الإنسان الذي يريد أن يعبر عن رأيه أن يلتزم النقد البناء الذي به يصلح ولا يفسد، أما من يستخدم حرية التعبير في التهكم بالأخرين تحت ستار النقد وهو يعلم أن نقده هذا أشبه بالطعن فإنه يكون منافقا، وفي ذلك يقول الحافظ ابن رجب الحنبلي (3): الومن أظهر التعيير إظهار السوء وإشاعته في قالب النصح، وزعم أنه إنما يحمله على ذلك العيوب إما عاما أو خاصا، وكان في الباطن إنما غرضه التعيير والأذى فهو

(1) هذا التعريف هو تعريف الدكتور أحمد مختار عمر والذي نسبه لعلماء النفس، معجم

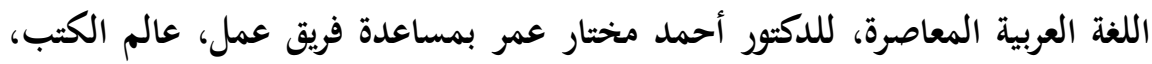

$$
\text { الطبعة الأولى، سنة 1429هـ- 2008م، } 3 \text { / } 2265 .
$$

(YY) معجم لغة الفقهاء، لمحمد رواس قلعجي وحامد صادق قنيبي، دار النفائس للطباعة والنشر والتوزيع، الطبعة الثانية، سنة 1408هـ- 1988م، ص 132.

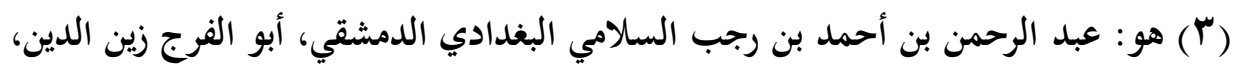

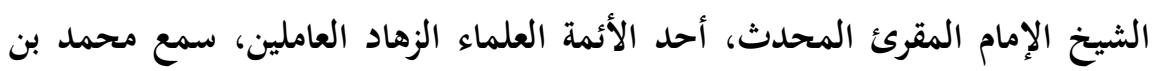

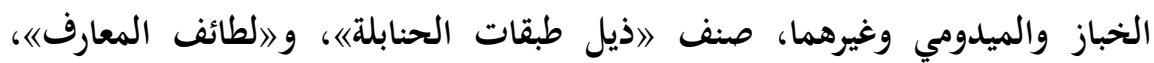
و 》(فتح الباري شرح صحيح البخاري《، وغيرها، توفي سنة (795 هـ). ينظر: الدرر

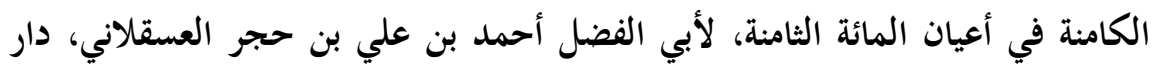
الجيل، بيروت، 3/ 108، والبدر الطالع بمحاسن من بعد القرن السابع، لمحمد بن علي بن محمد بن عبد الله الشوكاني اليمني، دار المعرفة، بيروت، لبنان، 1 / 328. 
دعاوى حرية التعبير وأثرها فى زعزعة الاستقرار والثوابت

من إخوان المنافقين الذين ذمهم الله في كتابه في مواضع" (1).

وبناء على ذلك فإن النقد لا بد أن يقوم على النصح لإصلاح عوج أو خلل سواء في الفرد أو المجتمع، ولا ينجر الناقد إلى التشهير بمن ينقده أو ينصحه فبدلا من أن يصلحه يفضحه، وقد حثت السنة النبوية على ذلك فقال النبي صلى لي الله عليه وسلم: 》من عير أخاه بذنب لم يمت حتى يعمله| (2).

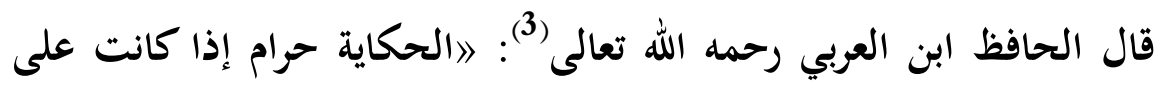
طريق السخرية والاستهزاء والاحتقار لما فيها من العجب بالنفس والاحتقار للخلق

(1) الفرق بين النصيحة والتعيير، لزين الدين عبد الرحمن بن أحمد بن رجب، علق عليه

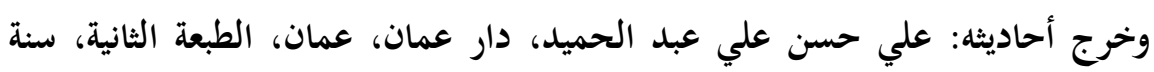
1409هـ- 1988م، ص 22

(Yr) أخرجه الترمذي في جامعه (2505) من حديث معاذ بن جبل رضي الله عنه. وقال: حديث غريب وليس إسناده بمتصل. وقال الملا علي القاري في مرقاة المفاتيح شرح مشكاة المصابيح، دار الفكر، بيروت، الطبعة الأولى، سنة 1422هـ- 2002م، 1474: الضعيف معمول به في الفضائل اتفاقا.

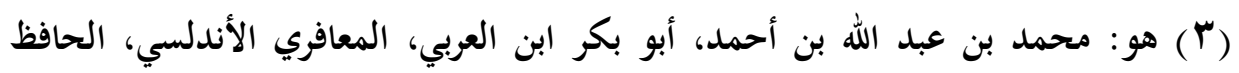

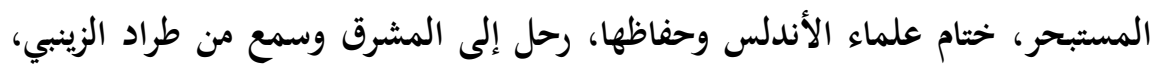

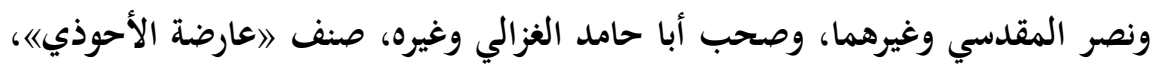
و أحكام القرآن/ وغيرهما، توفي سنة (543 هـ). ينظر: وفيات الأعيان، لشمس الدين بن خلكان، تحقيق: إحسان عباس، دار صادر، بيروت، الطبعة الأولى، سنة 1900،

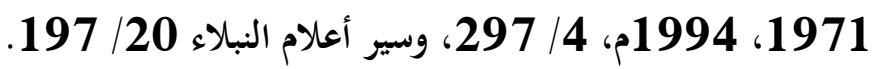


دعاوى حرية التعبير وأثرها فى زعزعة الاستقرار والثوابت

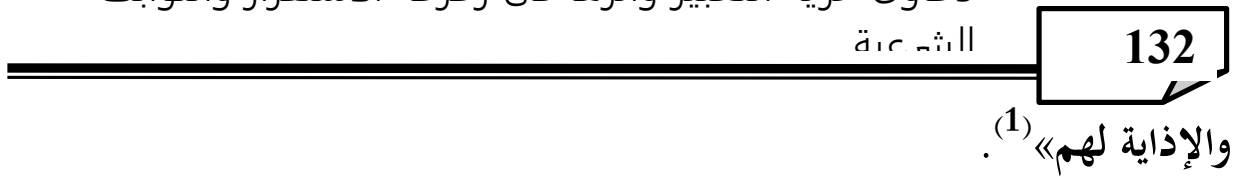

وحتى يكون النقد بناء يؤدي الغرض المرجو منه لا بد من توافر ضوابط

1- حسن القصد؛ لأن كل تكليف قد خالف القصد فيه قصد الشارع فهو

باطل (3)

2- الالتزام بالتثبت من النقل وحسن الفهم والرد، فحسن القصد من أعظم

نعم الله التي أنعم بها على عبده، بل ما أعطي عبد عطاء بعد الإسلام أفضل ولا الا أجلّ منهما، بل هما ساقا الإسلام وقيامه عليهما (4). 3- أن يحقق النقد مقاصد الشريعة وألَّا يخالفها.

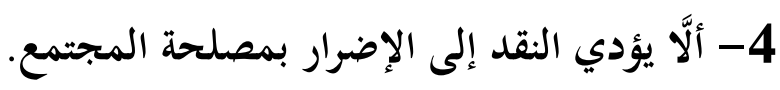

(1) عارضة الأحوذي، لأبي بكر ابن العبب، دار الكتب العلمية، بيروت، 9 / 310. (r) ينظر هذه الضوابط في بحث حرية الرأي والتعبير عنه في الشريعة الإسلامية التأصيل

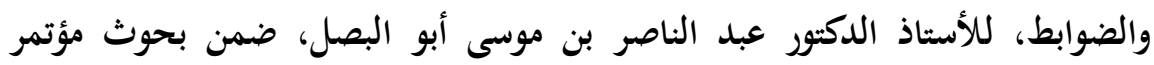

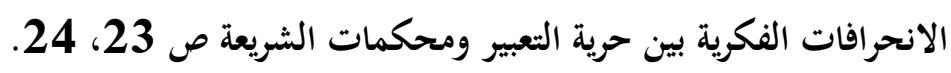

(ץ) كما قال إبراهيم بن موسى بن محمد الشاطبي، في الموافقات، تحقيق: أبو عبيدة مشهور

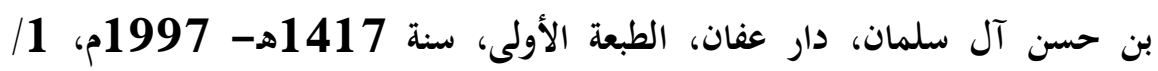

.316

(\& ) كما قاله ابن قيم الجوزية في إعلام الموقعين عن رب العالمين، تقديم وتخريج: أبو عبيدة

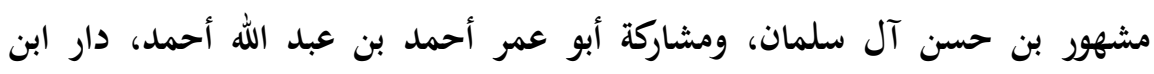

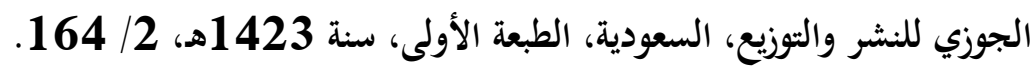

مجلة كلية البنات الأزهرية بطيبة الجديدة ـ بالأقصر

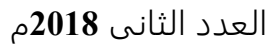


5- أن تكون الوسيلة المتبعة في النقد مشروعة.

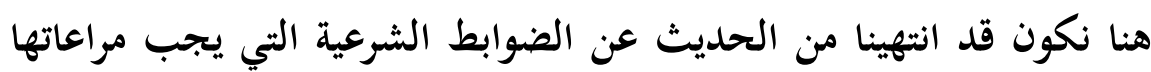

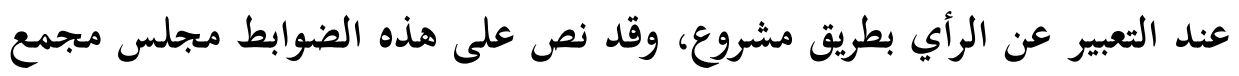
الفقه الإسلامي الدولي المنبثق عن منظمة المؤتمر الإسلامي المنعقد في دورته التاسعة عشرة في إمارة الثارقة بدولة الإمارات العربية المتحدة من 1- 5 جمادى الأولى سنة 1430هـ، الموافق 26- 30 إبريل، وبعد اطلاعه على إلى البحوث الواردة إلى المجمع بخصوص موضوع حرية التعبير عن الرأي ضوابطها

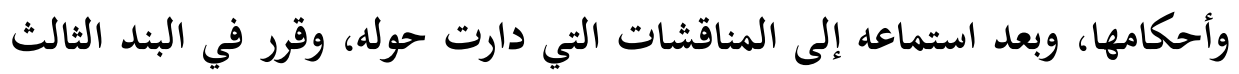
ما يلي: من أهم الضوابط الثرعية لممارسة حرية التعبير عن الرأي: 1- عدم الإساءة للغير بما يمس حياته أو عرضه أو سمعته أو مكانته الأدبية

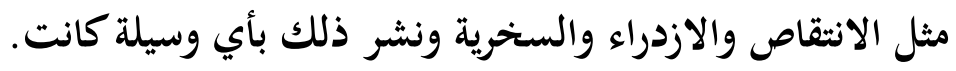
2- الموضوعية ولزوم الصدق والنزاهة والتجرد عن الهوى. 3- الالتزام بالمسئولية والمحافظة على مصالح المجتمع وقيمه. 4- أن تكون وسيلة التعبير عن الرأي مشروعة، فلا يجوز التعبير عن الرأي

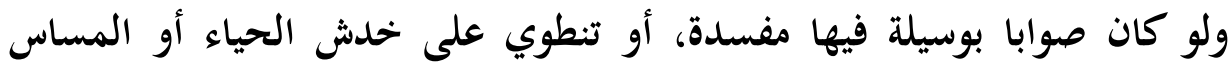
بالقيم، فالغاية المشروعة لا تبرر الوسيلة غير المشروعة.

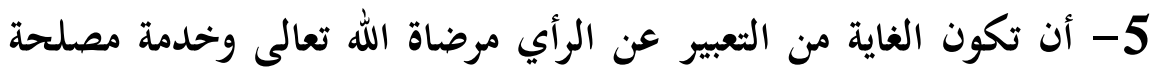
من مصالح المسلمين الخاصة أو العامة. 
دعاوى حرية التعبير وأثرها فى زعزعة الاستقرار والثوابت

6- أن تؤخذ بالاعتبارات المآلات والآثار التي قد تنجم عن التعبير عن

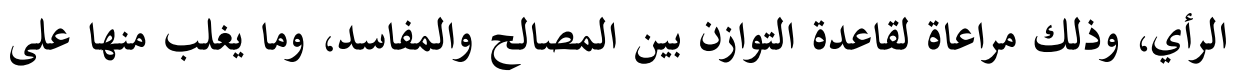
الآخر.

7- أن يكون الرأي المعبر عنه مستندا إلى مصادر موثوقة، وأن يتجنب

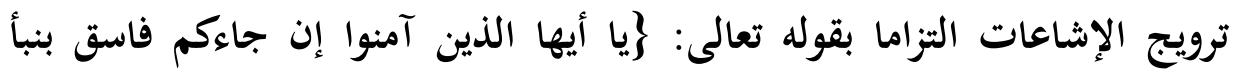

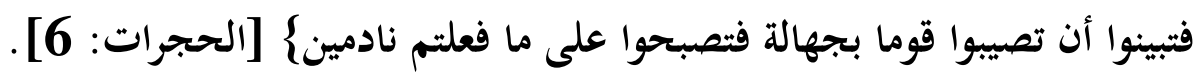

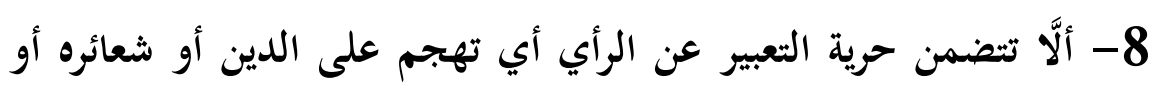
شرائعه أو مقدساته. 9- ألَّا تؤدي حرية التعبير عن الرأي إلى الإخلال بالنظام العام للأمة وإحداث الفرقة بين المسلمين. 
دعاوى حرية التعبير وأثرها فى زعزعة الاستقرار والثوابت

\section{المبحث الثالث}

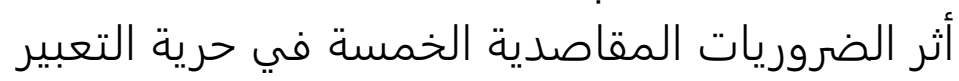
وضعت أحكام الثريعة الإسلامية لمراعاة مصالح الناس ودرء كافة الشرور والمفاسد عنهم؛ لكي تستقيم الحياة البشرية على نهج قويم، ويأمن فيها أهلوها بالخير والنعيم، يقول ابن قيم الجوزية)1: الشريعة مبناها وأساسها على الحكم ومصالح العباد في المعاش والمعاد، وهي عدل كلها ورحمة كلها ومصالح كلها وحكمة كلها، فكل مسألة خرجت عن العدل والجور وعن الرحمة إلى ضدها وعن المصلحة إلى المفسدة وعن الحكمة إلى البعث، فليست من الثريعة وإن أدخلت فيها بالتأويل، فالثريعة عدل الله بين عباده، ورحمثه بين خلقه وظله في أرضه، وحكمته الدالة عليه وعلى صدق رسوله صلى الله عليه وسلم أتم دلالة

(1) هو: محمد بن أبي بكر بن أيوب بن سعد الزرعي، أبو عبد الله شمس الدين الدمشقي،

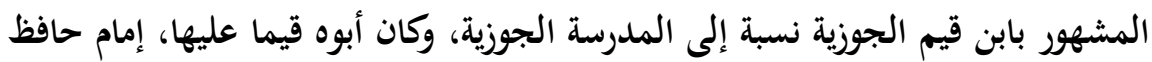

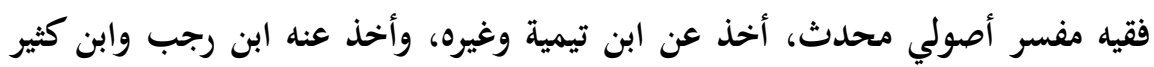
وغيرهما، صنف 》إعلام الموقعين《، و امدارج السالكين《 وغيرهما، وتوفي سنة (751 هـ). ينظر: ذيل طبقات الحنابلة، لعبد الرحمن بن أحمد بن رجب الحمبن الحنبلي، تحقيق:

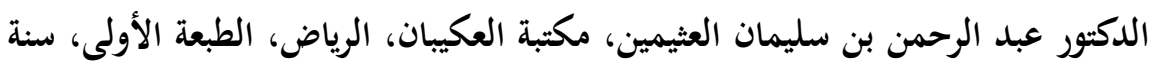

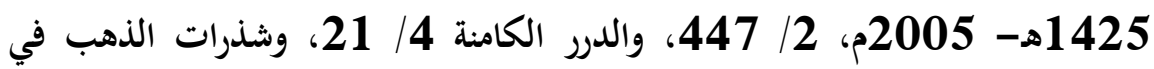
أخبار من ذهب، لعبد الحي بن أحمد ابن العماد الحنبلي، تحقيق: محمود الأرنؤوط وعبد القادر الأرنؤوط، دار ابن كثير، دمشق وبيروت، الطبعة الأولى، سنة 1406هـ-

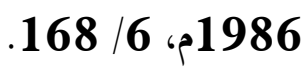


دعاوى حرية التعبير وأثرها فى زعزعة الاستقرار والثوابت

وأصدقها《(1)

ولتحقيق تلك المصالح لا بد من تحقيق ضروريات خمس، تلك الضروريات هي حفظ الدين والنفس والنسل والمال والعقل، وفي ذلك يقول الشاطبي (2): 》ا اتفقت الأمة بل سائر الملل على أن الشريعة وضعت للمححافظة على الضروريات

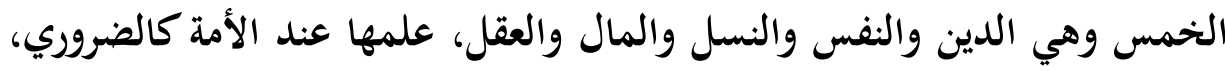

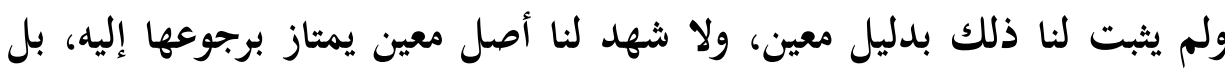

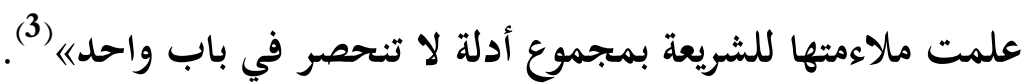
أما الضرورة الأولى وهي حفظ الدين فعناه: تثبيت أركان الدين وأحكامه في الوجود الإنساني والحياة الكونية، والعمل على إبعاد ما يخالف دين الفين الله الله

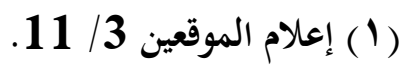

(T) هو: إبراهيم بن موسى بن محمد اللخمي الغرناطي المالكي الشاطبي، أبو إسحاق،

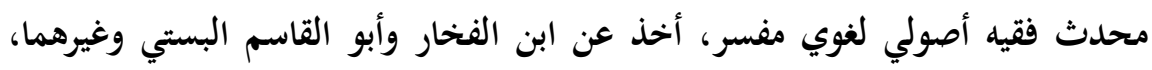

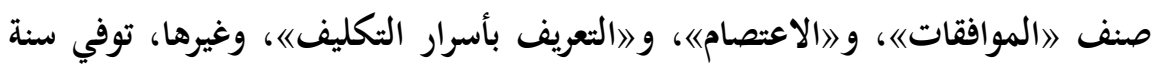

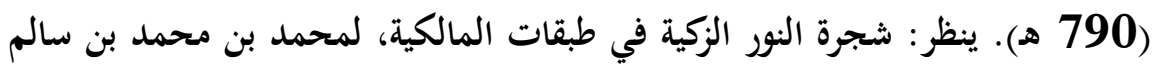

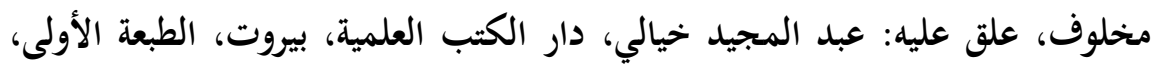

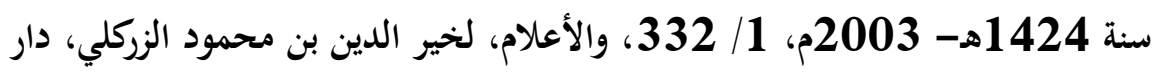
العلم للملايين، الطعة الخامسة عشر، سنة 2002م، 1/ 75، ومعجم المؤلفين،

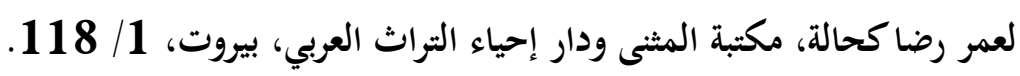

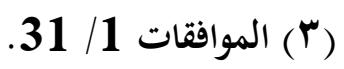




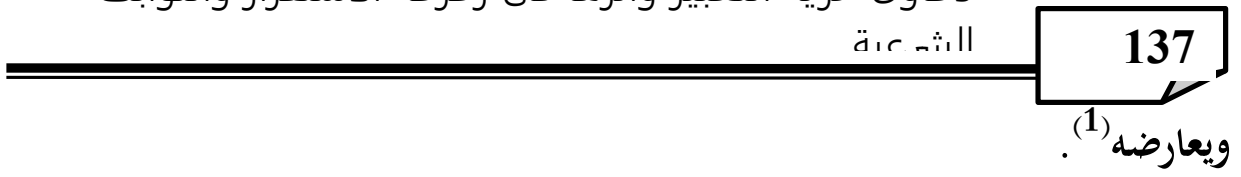

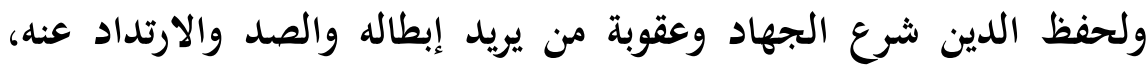

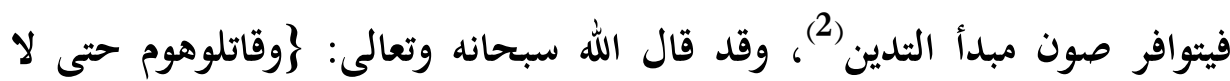

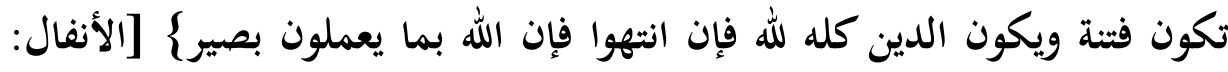

قال ابن جرير الطبري في تفسير تلك الآية: 》فقاتلوهم حتى لا يكون شرك

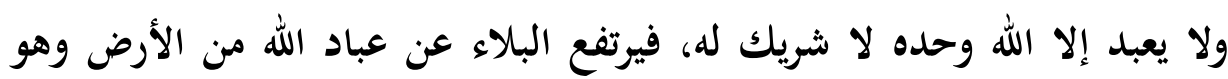
الفتنة، \}ويكون الدين كله للهج يقول: حتى تكون الطاعة والعبادة كلها لله خالصة الله

$$
\text { دون غيرهن }
$$

وأكد النبي صلى عليه وسلم على حفظ الدين وعدم تضييعه في نصوص

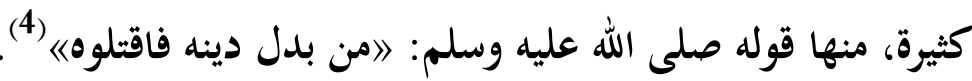

(1) ينظر : علم المقاصد الشرعية، لنور الدين بن مختار الخادمي، مكتبة العبيكان، السعودية،

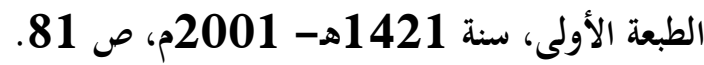

(ץ' ينظر : أصول الفقه الإسلامي، للدكتور وهبة الزحيلي، دار الفكر للطباعة والنشر، دمشق،

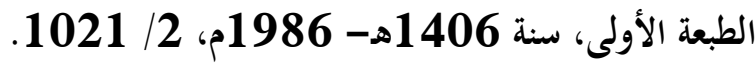

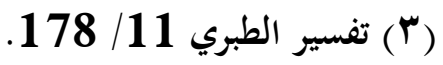
(؛) أخرجه البخاري في صحيحه (3017، 6922) من حديث عبد الله بن عباس رضي

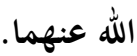


قال ابن الأثير (1) في معنى هذا الحديث: المن خرج من الإسلام إلى غيره لا

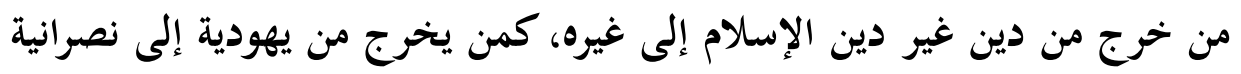
أو مجوسية، ومن فعل ذلك من أهل الذمة لم يستتب ولم يقتله (2).

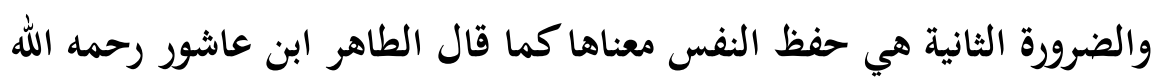

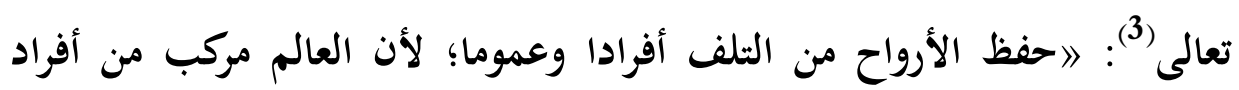

(1) هو: المبارك بن محمد بن عبد الكريم، مجد الدين أبو السعادات الشيباني الجزري

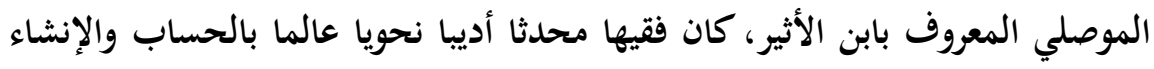

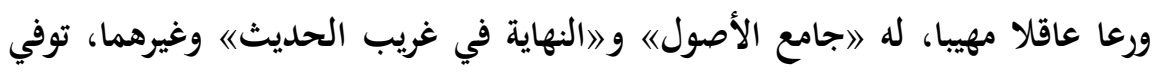

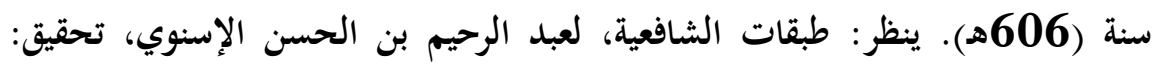

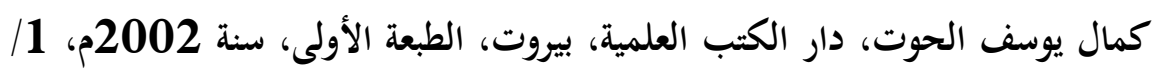

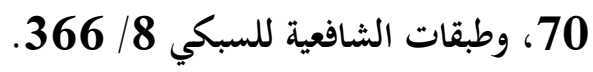

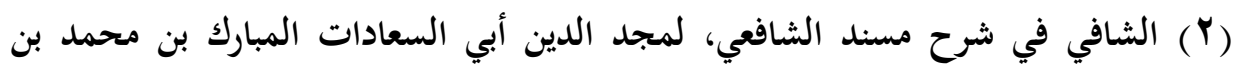

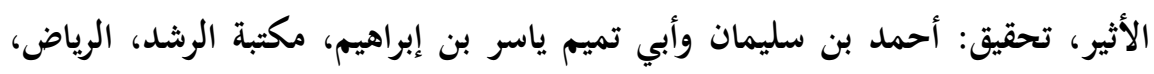

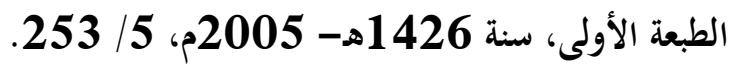

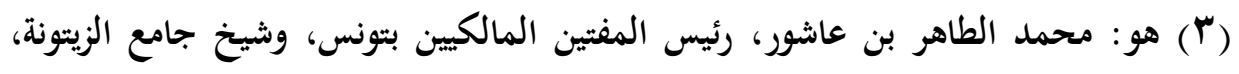

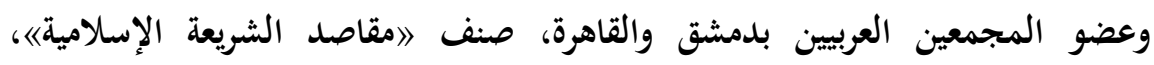

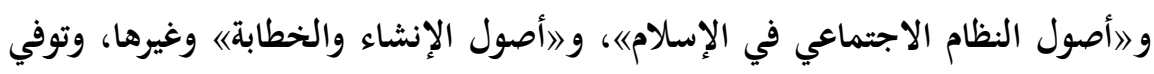
سنة (1393هـ- 1973م). ينظر: الأعلام 174 / 174. 
الإنسان، وفي كل نفس خصائصها التي بها بعض قوام العالمه|1. ولتحقيق حفظ النفس أوجب الله تعالى تناول الطعام والشراب وارتداء

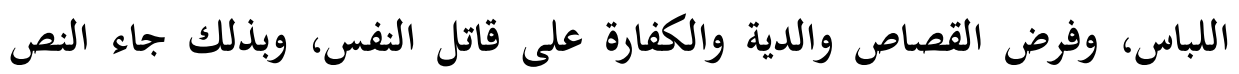

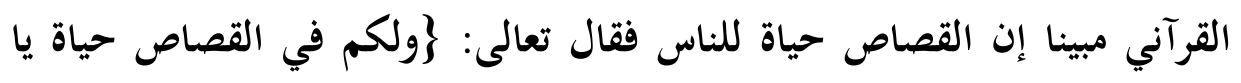

أولي الألباب\{ [القصاص: 179].

قال الشاطبي: 》شرع القصاص حفظا للنفوس، فقتل النفس في القصاص

محافظة عليها بالقصدي (2).

وعرف الطاهر ابن عاشور أيضا الضرورة الثالثة وهي حفظ العقل بقوله:

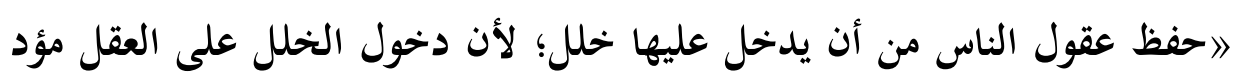

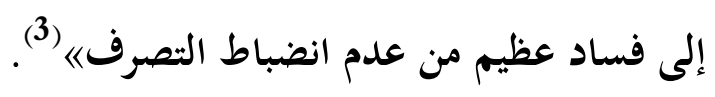

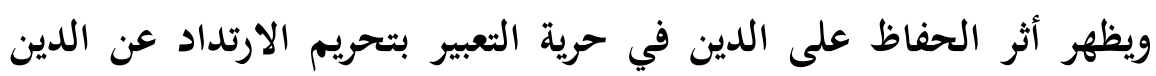
والدعوة إلى الأفكار التي تدعو إلى إبعاد الدين عن الحياة.

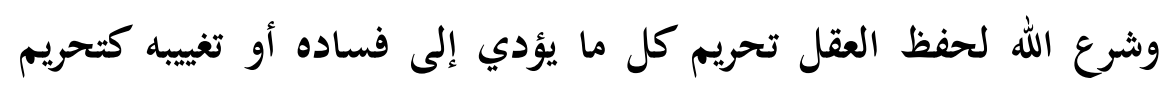

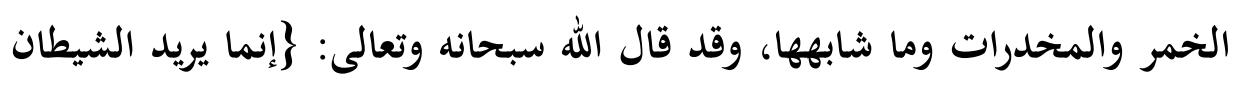
أن يوقع بينكم العداوة والبغضاء في الخمر والميسر ويصدكم عن ذكر الله وعن واله

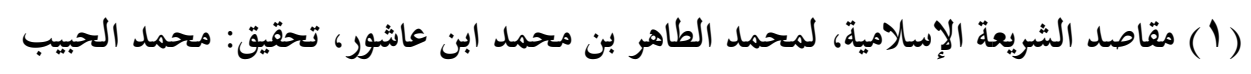

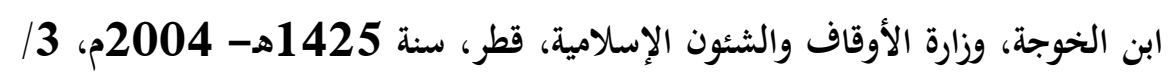

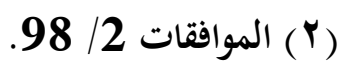

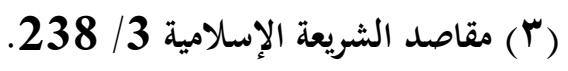




\section{الصلاة فهل أنتم منتهون\{ [المائدة: 91].}

قال الواحدي(1) عند تفسير هذه الآية: \قال أهل المعاني: إن الشيطان يزين لهم ذلك حتى إذا سكروا وزالت عقولهم أقدموا من المكاره والمقابح على ما كانت تمنعه منه عقولهم/ (2).

وقال أيضا عند تفسير الثق الأخير من الآية والحديث عن الصد عن ذكر الله والصلاة: اوذلك أن من اشتغل بشرب الخمر والقمار ألهاه ذلك عن ذكر الله جل وعز بالتعظيم والشكر على آلائه وعن عبادته《 (3).

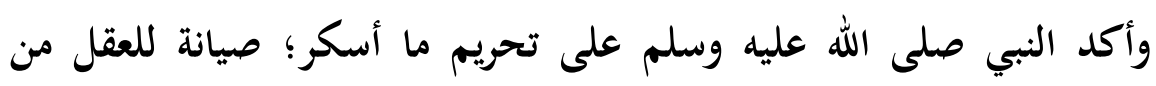
التغييب والزوال فقال: اوكل مسكر حرام|ن(4).

(1) هو: علي بن أحمد بن محمد بن علي بن متويه، أبو الحسن الواحدي، كان أستاذ عصره

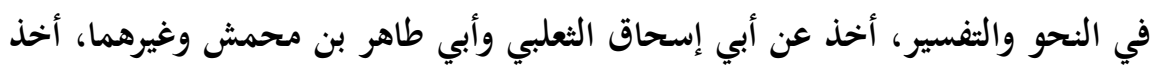

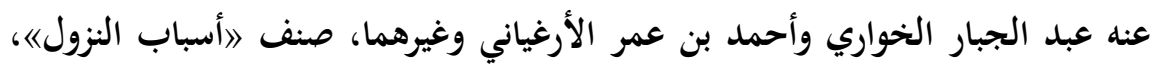
و التفسير البسيط《 وغيرهما، وتوفي سنة (468ه). انظر: معجم الأدباء 4 1659، ووفيات الأعيان 18 1840.

(Y) التفسير البسيط، لأبي الحسن علي بن أحمد الواحدي، تحقيق: لجنة علمية من جامعة

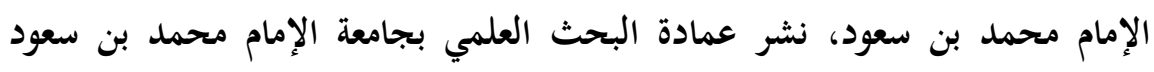

الإسلامية، الطبعة الأولى، سنة 1430هـ، 71 / 511.

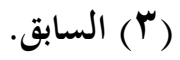

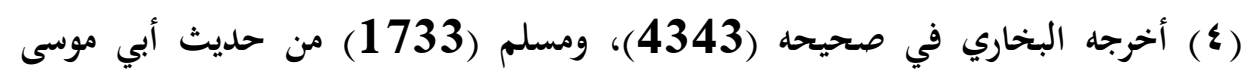
الأشعري رضي الله عنه. 
دعاوى حرية التعبير وأثرها فى زعزعة الاستقرار والثوابت

ويظهر أثر الحفاظ على العقل في حرية التعبير فإنها تحميه من مفسدات العقل بنوعيه: المفسد الحسي كالخمر والمخدرات وما غيب العقل من مشروب أو مأكول، والمفسد المعنوي كالأفكار الفاسدة التي تجر إلى الردة والإلحاد. وأما الضرورة الرابعة وهي حفظ المال فمعناه: إنماؤه وإثراؤه وصيانته من التلف والضياع والنقصان(1). ولحفظ المال وتحقيقه شرع سبحانه وتعالى تحريم السرقة وإيجاب حد القطع على من سرق، فقال سبحانه وتعالى: \}والسارق والسارقة فاقطعوا أيديهما جزاء بما كسبا نكالا من الله والله عززي حكيم\{ [المائدة: 38]. ومعلوم أن العقوبات في الثريعة الإسلامية زواجر لردع مقترفي الآثام والذنوب، لذا يقول

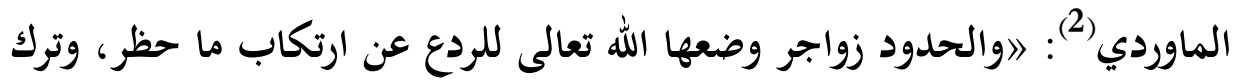
ما أمر به لما في الطمع من مغالبة الثهوات الملهبة عن وعيد الآخرة بعاجل اللذة، فجعل الله تعالى من زواجر الحدود ما يردع به ذا الجهالة حذرا من ألم

(1) (1) علم المقاصد الشرعية ص 84.

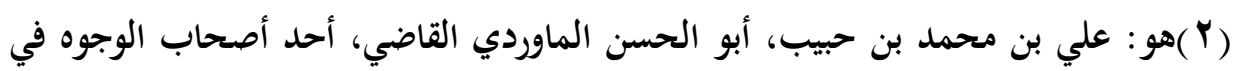

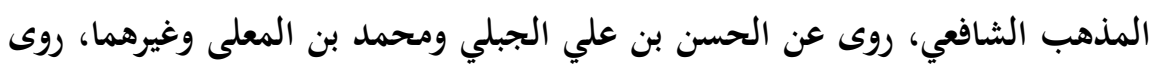

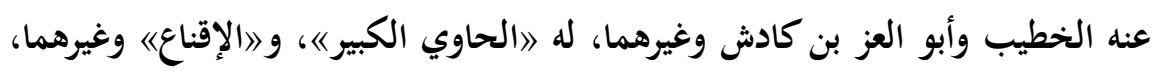
توفي سنة (450هـ). ينظر: طبقات الشافعية للسبكي 5 / 267، وطبقات الشافعيين، لأبي الفداء إسماعيل بن عمر بن كثير، تحقيق: الدكتور أحمد عمر هاشم والدكتور محمد زينهم محمد عزب، مكتبة الثقافة الدينية، القاهرة، سنة 1413هـ- 1993م،

ص 418 
العقوبة وخيفة من نكال الفضيحة؛ ليكون ما حظر من محارمه ممنوعا، وما أمر به من فروضه متبوعا، فتكون المصلحة أعم والتكليف أتمه (1).

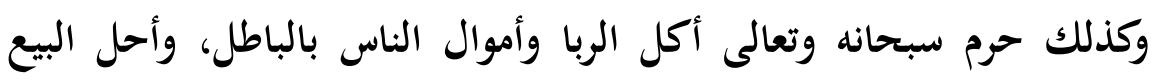
وغير ذلك.

والضرورة الخامسة وهي حفظ النسل فمعناه: التناسل والتوالد لإعمار الكون، وحفظ النسب معناه: القيام بالتناسل المشروع عن طريق العلاقة الزوجية الشرعية... وحفظ العرض معناه: صيانة الكرامة والعفة والشرف (2.).

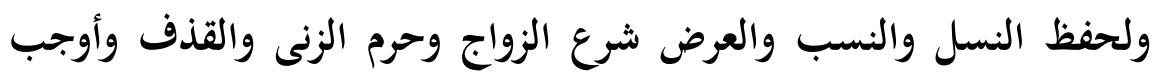

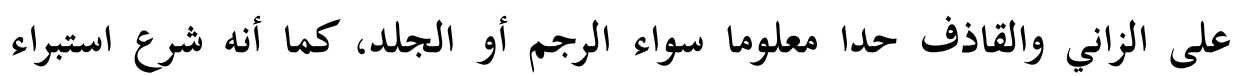
الأرحام لمنع اختلاط الأنساب.

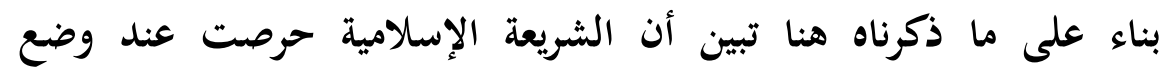

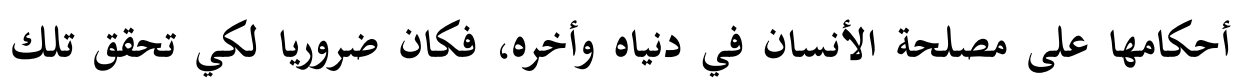

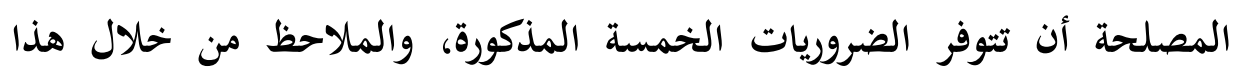

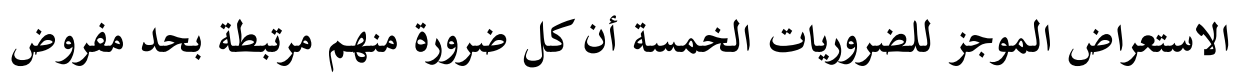

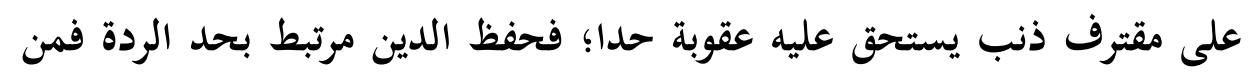

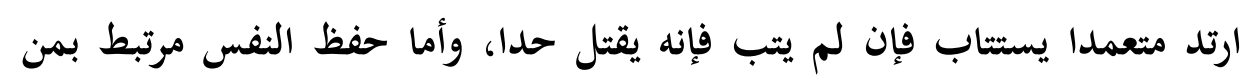

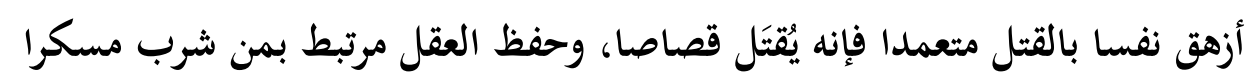

(1) الأحكام السلطانية، لأبي الحسن علي بن محمد بن حبيب الماوردي، دار الحديث، القاهرة، ص 325.

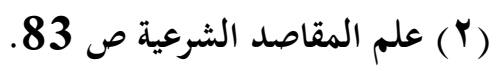


دعاوى حرية التعبير وأثرها فى زعزعة الاستقرار والثوابت

فغيب عقله فإنه يجلد حدا، وأما حفظ المال فإنه مرتبط بحد السرقة حيث إن

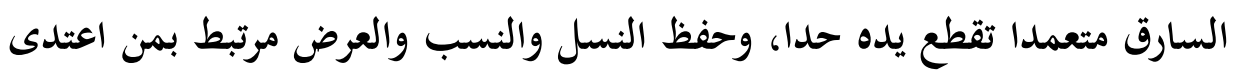

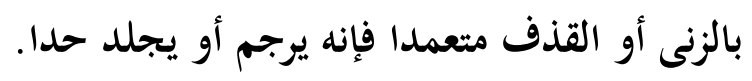

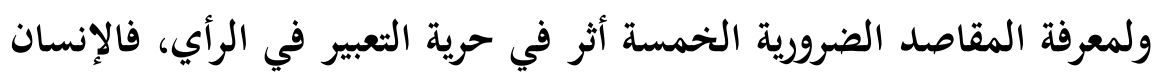

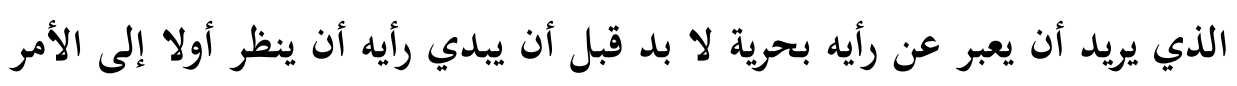

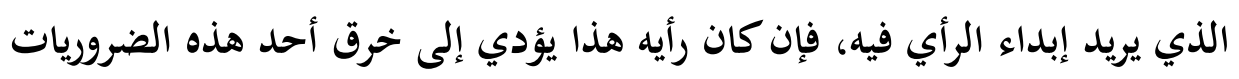

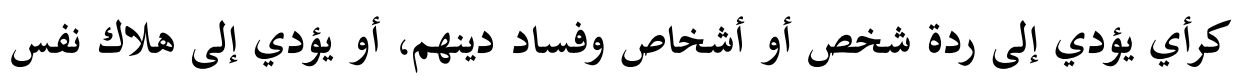

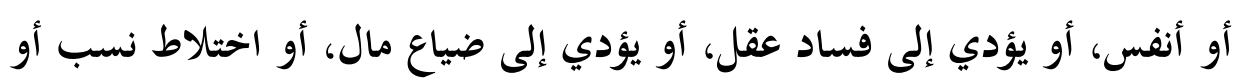

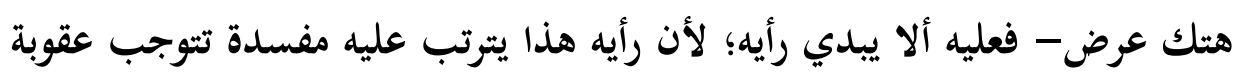
شرعية. 
دعاوى حرية التعبير وأثرها فى زعزعة الاستقرار والثوابت

\section{المبحث الرابع}

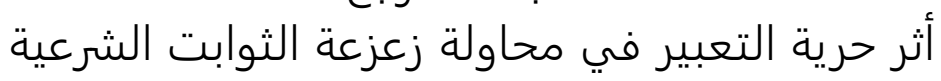

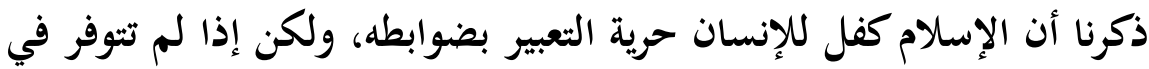

التعبير بالرأي تلك الضوابط فإنها تؤدي إلى زعزعة الثوابت على المستويين الفردي والمجتمعي، وهذه الزعزعة تتعلق بالعقيدة والأخحلاق والأحكام الثرعية، وتفنيد ذلك وبيانه فيما يلي:

أولا: أثر حرية التعبير في محاولة زعزعة ثوابت العقيدة:

العقيدة هي ما عقد عليه القلب، ويكون باطمئنان القلوب على شيء ما يجوز

$$
\text { أن ينحل عنه (1). }
$$

وعقيدة الإسلام قائمة على التوحيد بالله سبحانه وتعالى وأنه لا شريك ولا ند له في ملكه، بل هو المتفرد بالعبادة عمن سواه المستحق بالحمد والثناء، ويكون المسلم مسلما بنطق الشهادتين- شهادة أن لا إله إلا الله وأن محمدا رسول اللهمرة واحدة في عمره كله، يقول النووي رحمه الله تعالى: اواتفق أهل السنة من المحدثين والفقهاء والمتكلمين على أن المؤمن الذي يحكم بأنه من أهل القبلة ولا يخلد في النار لا يكون إلا من اعتقد بقلبه دين الإسلام اعتقادا جازما خاليا من الشكوك ونطق بالشهادتين، فإن اقتصر على إحداهما لم يكن من أهل القبلة أصلا إلا إذا عجز عن النطق لخلل في لسانه، أو لعدم التمكن منه لمعاجلة المنية، أو لغير ذلك فإنه يكون مؤمنا أما إذا أتي بالشهادتين، فلا يشترط معهما أن يقول:

(1) التعريفات الفقهية، لمحمد عميم الإحسان البركتي، دار الكتب العلمية، بيروت، الطبعة الأولى، سنة 1424هـ 1424 
وأنا بريء من كل دين خالف الإسلام إلا إذا كان من الكفار الذين يعتقدون

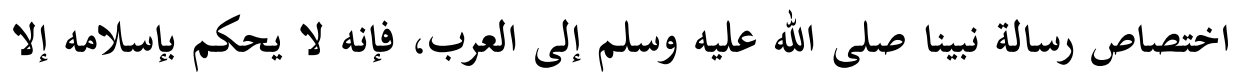
بأن يتبرأه (1).

والأدلة من الكتاب والسنة دالة على عقيدة التوحيد، فمن الكتاب قوله

تعالى: \}وإلاهكم إله واحد لا إله إلا هو الرحمن الرحيم\{ [البقرة: 163]

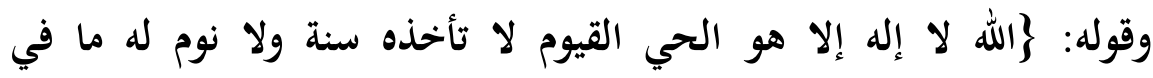

السماوات وما في الأرض من ذا الذي يشفع عنده إلا بإذنه؛ [البقرة: 255]. وقوله: جشهد الله أنه لا إله إلا هو والملائكة وأولوا العلم قائما بالقسط لا إله إله

إلا هو العزيز الحكيم\{ [آل عمران: 118].

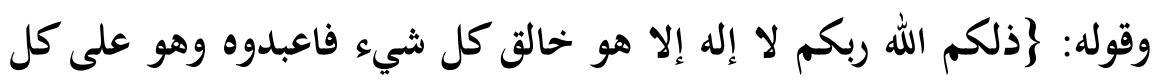

شيء وكيل\{ [الأنعام: 102].

وقوله: \}وما أمروا إلا ليعبدوا إلاها واحدا لا إله إلا هو سبحانه عما يشركونج

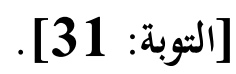

وقوله: \}إنني أنا الله لا إله إلا أنا فاعبدني وأقم الصلاة لذكري\{ [طه: 14].

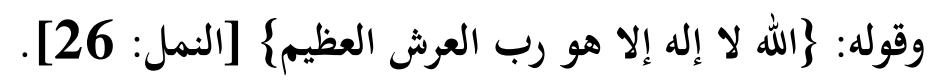

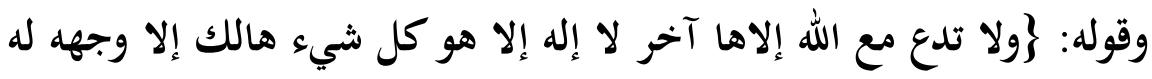

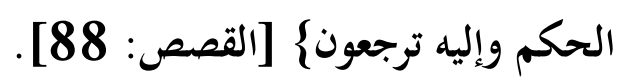

وغير ذلك من الآيات الكريمة التي دلت توحيده وتفرده بالعبادة، ومن السنة

(1 ) شرح النووي على مسلم 1 / 149. 
النبوية قوله صلى الله عليه وسلم: ابني الإسلام على خمس: شهادة أن لا إله إلا

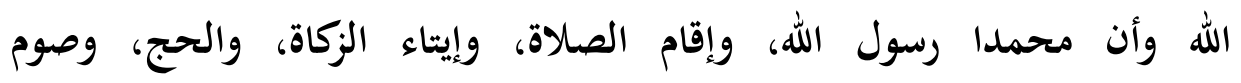
رمضان《)

وقوله: 》امن شهد أن لا إله إلا الله، واستقبل قبلتنا وصلى صلاتنا وأكل ذبيحتنا، فهو المسلم له ما للمسلم وعليه ما على المسلمه (2.). وقوله: 》أمرت أن أقاتل الناس حتى يقولوا: لا إله إلا الله. فمن قال: لا لا إله إلا الله. فقد عصم مني ماله ونفسه إلا بحقه وحسابه على اللهی) (3).

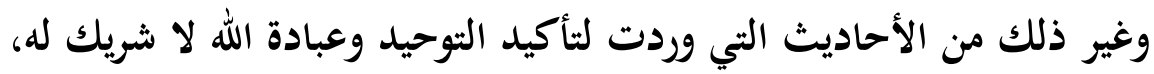
وهذه هي عقيدة الإسلام النقية التي لا غبار فيها. وقد قررت الشريعة الإسلامية حماية العقيدة من طريقين:

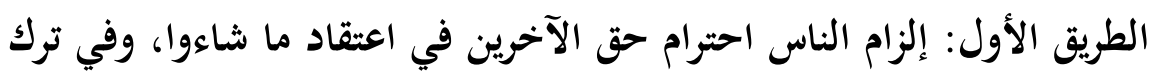

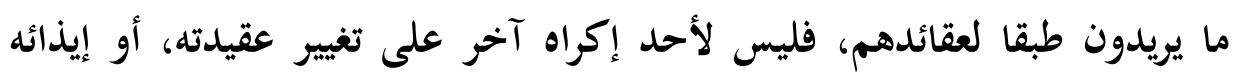
بسبب ممارسة عبادته. الطريق الثاني: إلزام صاحب العقيدة نفسه أن يعمل على حماية عقيدته

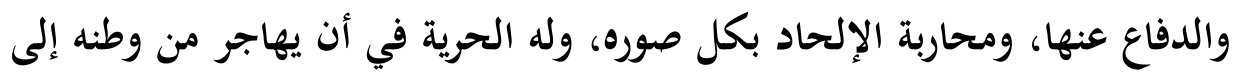
(1) أخرجه البخاري في صحيحه (8)، ومسلم (16) من حديث عبد الله بن عمر رضي الله عنه. (Yr) أخرجه البخاري في صحيحه (393) من حديث أنس بن مالك رضي الله عنه.

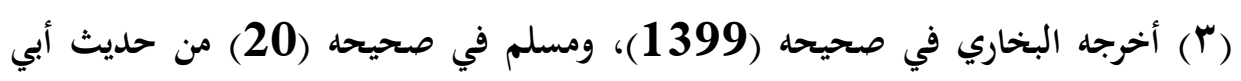
هريرة رضي الله عنه. 
دعاوى حرية التعبير وأثرها فى زعزعة الاستقرار والثوابت

أي بلد آخر، إذا عجز عن حماية نفسه، ولا فرق في ذلك بين المسلم؛ لقوله

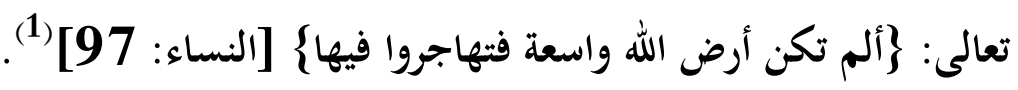

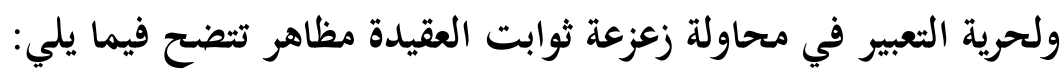

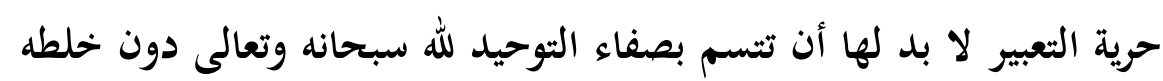

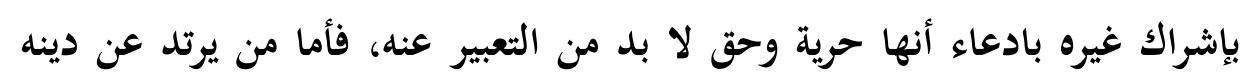

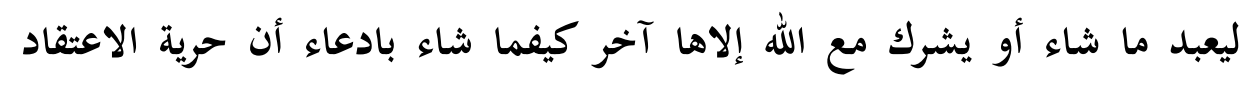

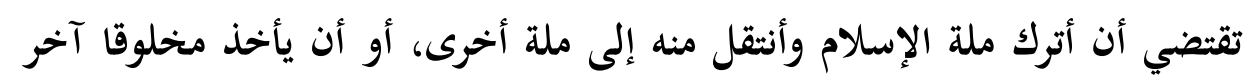
يعبده مع الله سبحانه وتعالى أو يتقرب به إلى الله.

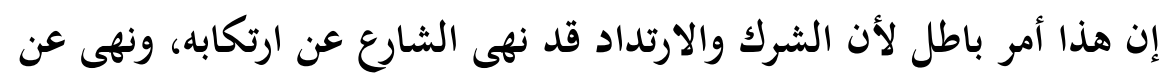

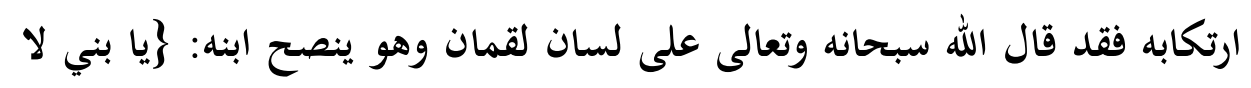

تشرك بالله إن الشرك لظلم عظيمج [لقمان: 113]. بل هو كبيرة من الكبائر، وأول الموبقات التي أمر النبي صلى الله عليه وسلم

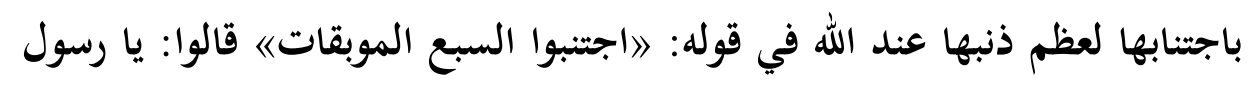
الله، وما هن؟ قال: 》الثرك بالله ..."

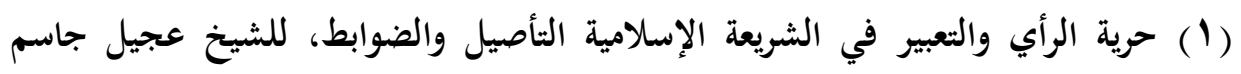

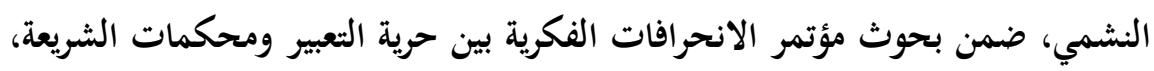

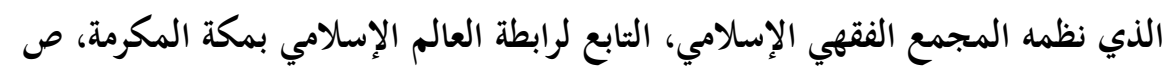

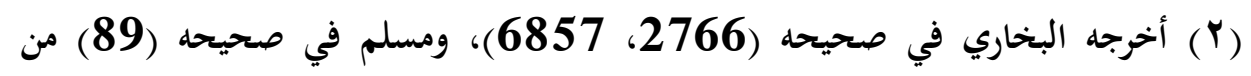
حديث أبي هريرة رضي الله عنه. 
والأمر في الحديث يفيد الوجوب؛ لأنه لا قرينة صارفة له عن إطلاقه، وبناء

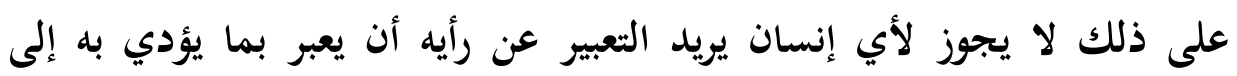

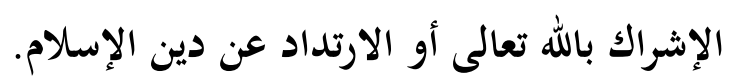

ومن أثر زعزعة حرية التعبير للثوابت الشرعية للعقيدة التشكيك في وجود اللهادماد الله

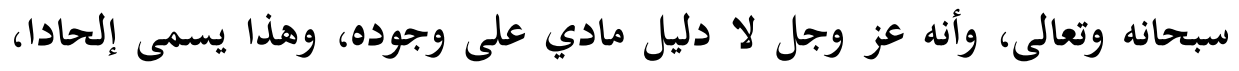

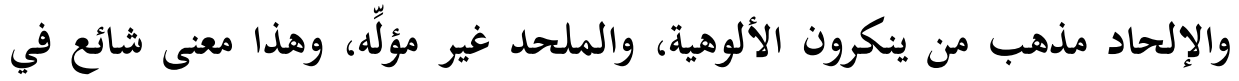
تاريخ الفكر الإنساني، ويتضمن رفض أدلة المفكرين على وجود الله، وقد رُمبي به بعض الفلاسفة والعلماء قديما وحديثان (1).

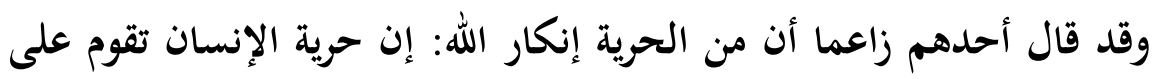

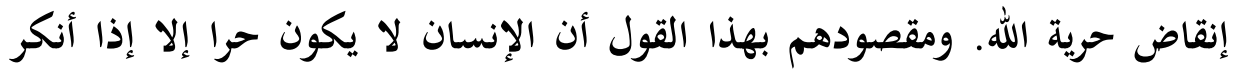

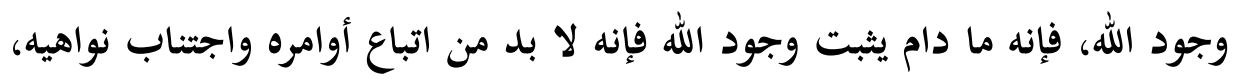
وهذا مخالف للحرية التامة، فإذا قضى على فكرة وجود الله فقد ثبتت الحرية وإلا فلا 2 (2).

وبناء على ذلك فإن حرية التعبير المطلقة دون اتباع ضوابط شرعية قائمة

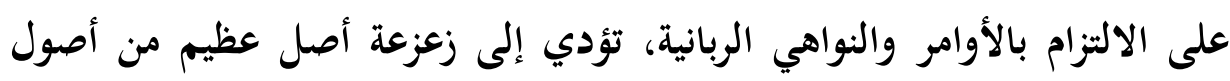

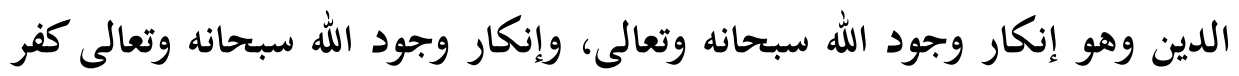

(1) ينظر: المعجم الفلسفي، مجمع اللغة العببية بالقاهرة، الهيئة العامة لشئون المطابع

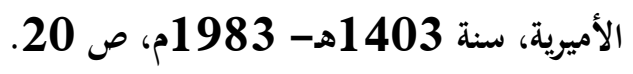

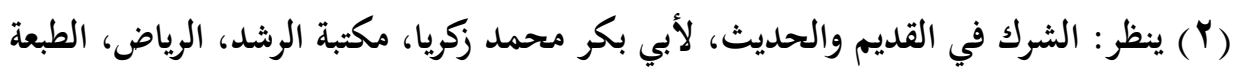

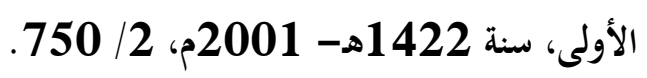


دعاوى حرية التعبير وأثرها فى زعزعة الاستقرار والثوابت

يستحق من اعتقده متعمدا العقاب في الدنيا والآخرة إن لم يتب إلى الله سبحانه

وتعالى.

ومن أثر زعزعة حرية الثعبير للثوابت الشرعية للعقيدة التشكيك في سنة النبي

صلى الله عليه وسلم؛ فقد شاهدنا وسمعنا على شاشات الإعلام في الآونة الأخيرة

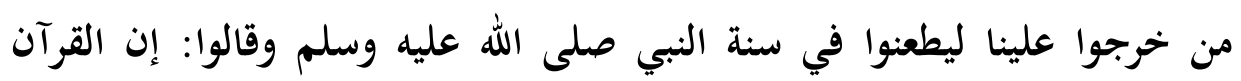
وحده في غنى عن السنة النبوية. وانهالوا طعنا في أصح كتابين بعد القرآن وهما

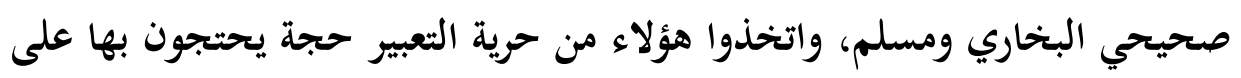

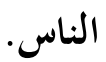

وهؤلاء وهموا فيما قالوا، فخالفوا ما آمنوا به واعتبروه المصدر الأوحد

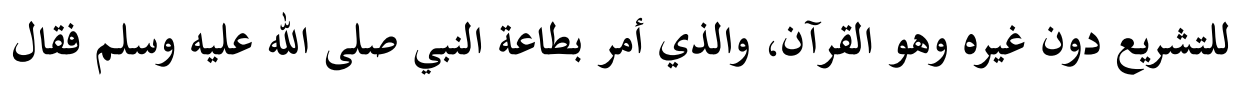

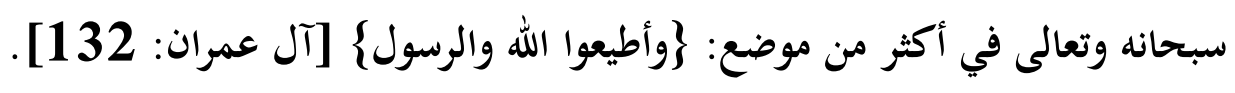

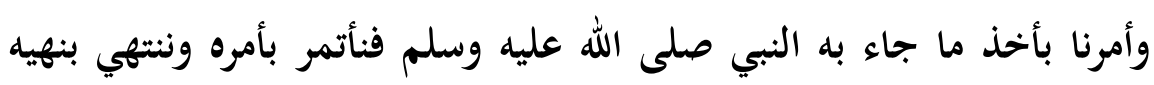

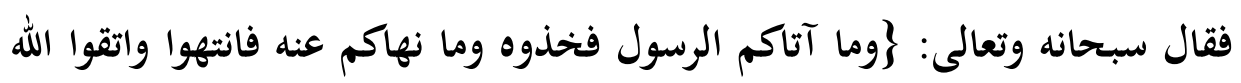
إن الله شديد العقاب\{ [الحشر : 7 ]. قال التستري(1) عند تفسيره هذه الآية: أصول مذهبنا ثلاث: أكل الحل الحلال،

(1) هو : سهل بن عبد الله بن يونس بن عيسى بن عبد الله بن رفيع، أبو محمد التستري، أحد التحال

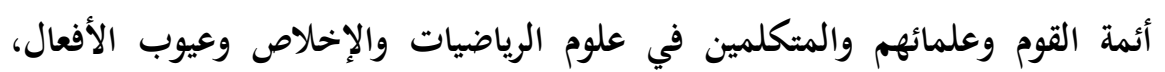

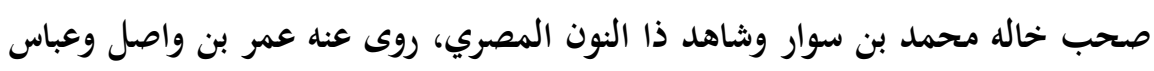

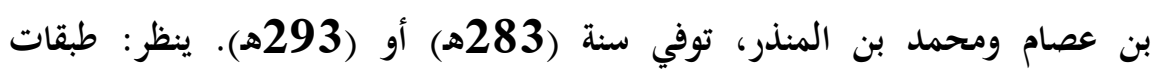
الصوفية، لأبي عبد الرحمن محمد بن الحسين السلمي، تحقيق: مصطفى عبد القادر العية 
دعاوى حرية التعبير وأثرها فى زعزعة الاستقرار والثوابت

$$
\text { är-ill }
$$

والاقتداء بالرسول صلى الله عليه وسلم في الأخلاق والأفعال، وإخلاص النية في

$$
\text { جميع الأعمال《) (1). }
$$

والسنة بالنسبة للكتاب إما أن تكون مؤكدة لما في القرآن، وإما مفصلة ومفسرة لما جاء مجمالا في القرآن، وإما مثبتة حكما لم يرد في القرآن الكريم (2)، وقد قال النبي صلى الله عليه وسلم: 》أوتيت الكتاب ومثله معله| (3). قال ابن قتيبة(4) في بيان المعنى المقصود من هذا الحديث: اليريد أنه أوتي

عطا، دار الكتب العلمية، بيروت، الطبعة الأولى، سنة 1419هـ- 1998م، ص

\section{1629، ووفيات الأعيان 2}

(1) تفسير التستري، لأبي محمد سهل بن عبد الله التستري، جمعها: أبو بكر محمد البلدي،

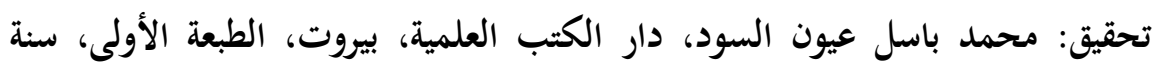

\section{3هـ، ص 165}

(Yr) ينظر : علم أصول الفقه، لعبد الوهاب خلاف، أعده واعتنى به: محمد أبو الخير السيد،

مؤسسة الرسالة ناشرون، بيروت، الطبعة الأولى، سنة 1429هـ- 2008م، ص 35. (r) أخرجه أبو داود في سننه (4604) من حديث المقدام بن معد يكرب رضي الله عنه.

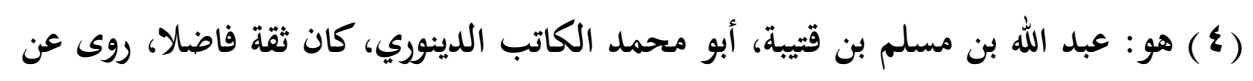

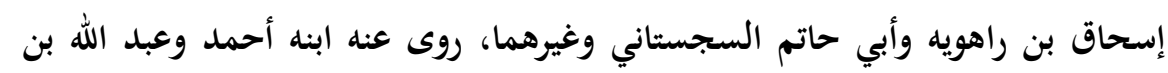

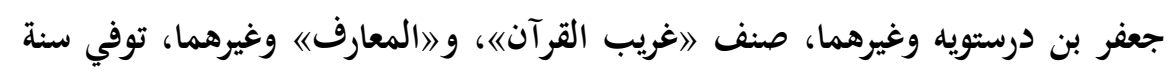
(276هـ). انظر: تاريخ بغداد 11/ 411، ونزهة الألباء في طبقات الأدباء ص 
وقال الخطابي(2) فيه شرحه: (ايحتمل وجهين من التأويل: أحدهما: أن يكون معناه أنه أوتي من الوحي الباطن غير المتلو مثل ما أعطي من الظاهر المتلو،

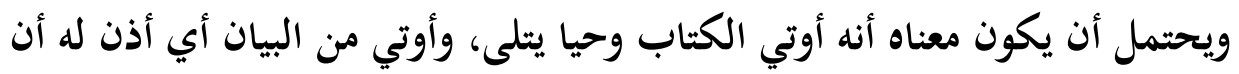

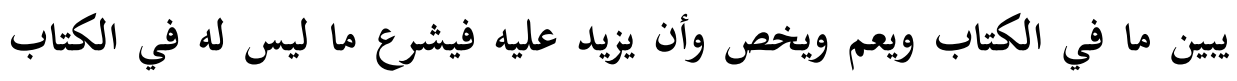

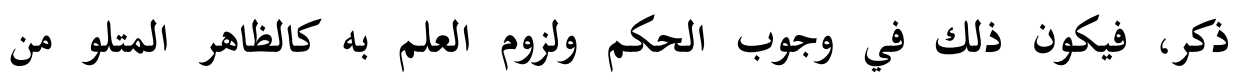
القرآن (3) فيكو، وبناء على ذلك فإن حرية التعبير بهذه الصورة تتسبب في زعزعة أحد أهم الثوابت الشرعية في العقيدة الإسلامية.

(1) تأويل مختلف الحديث، لأبي محمد عبد الله بن مسلم بن قتيبة، المكتب الإسلامي،

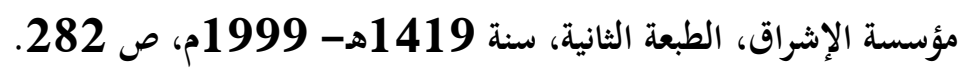

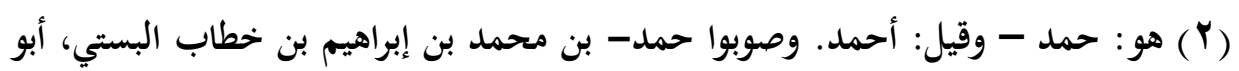

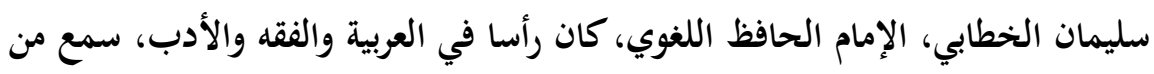

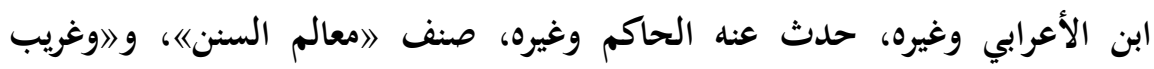

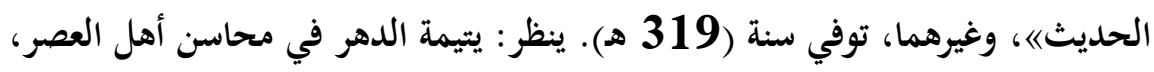

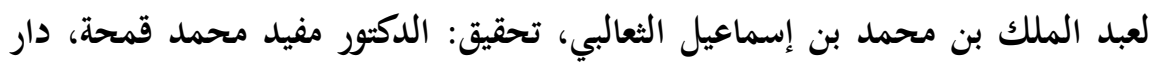

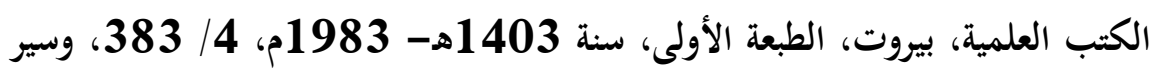

$$
\text { أعلام النبلاء } 17 \text { / } 25 .
$$

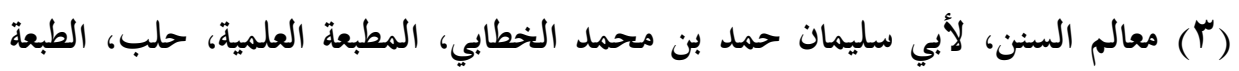
الأولى، سنة 1351هـ- 1932م، 4 / 298. 
ومن أثر حرية التعبير والرأي في زعزعة أحد الثوابت الشرعية للعقيدة الطعن في الصحابة وكبار رواتهم المكثرين عن النبي صلى الله عليه وسلم كأبي هريرة

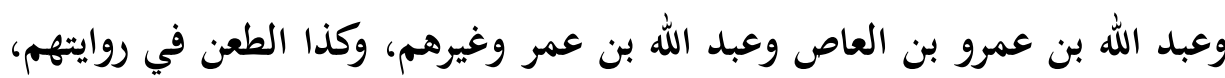

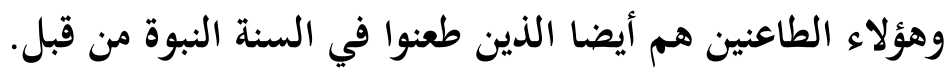

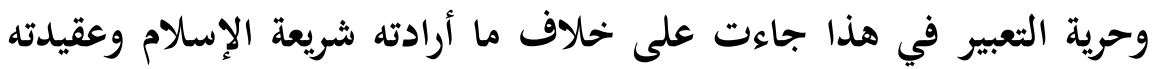
الغراء النقية؛ لأن هؤلاء الصحابة زكاهم الله سبحانه وتعالى في كتابه الكريم فقال :

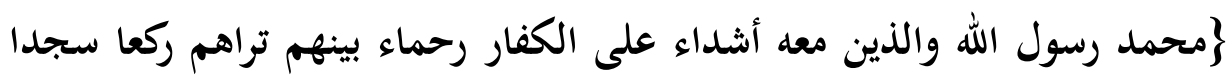

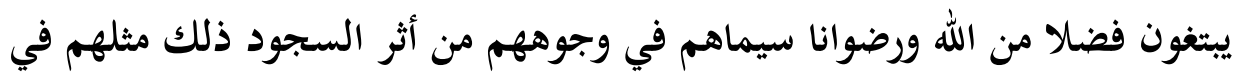

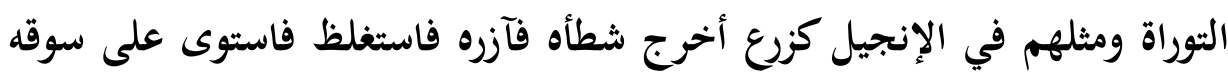
يعجب الزراع ليغيظ بهم الكفار وعد الله الذين آمنوا وعملوا الصالحات منهم الإنه

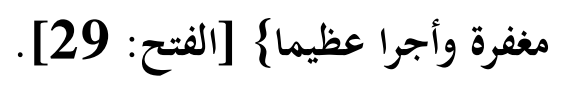

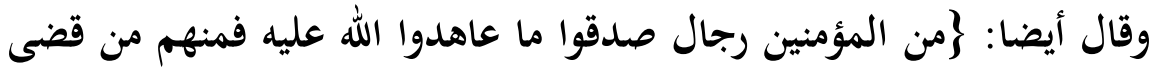

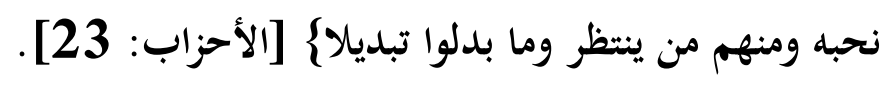

وقد نهى النبي صلى الله عليه وسلم عن سب الصحابة فقال: الا تسبوا

أصحابي، فلو أن أحدكم أنفق مثل أحد ذهبا، ما بلغ مد أحدهم ولا نصيفهيه (1).

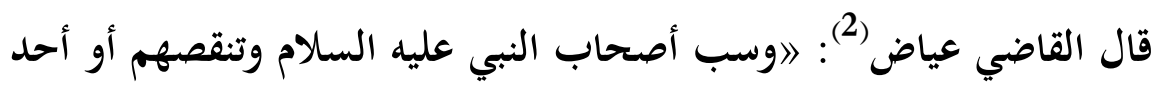

(1) أخرجه البخاري في صحيحه (3673)، ومسلم في صحيحه (2541) من حديث أبي سعيد الخدري رضي الله عنه.

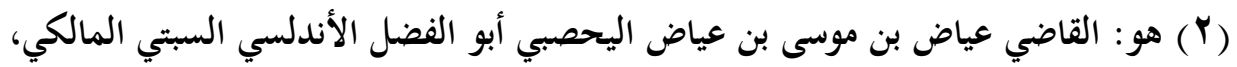

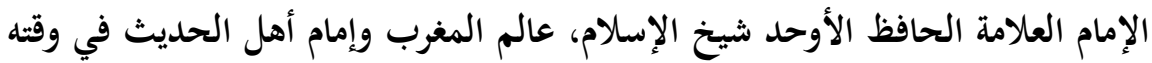


دعاوى حرية التعبير وأثرها فى زعزعة الاستقرار والثوابت

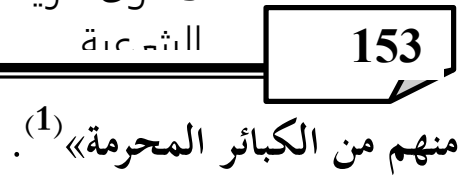

فإن كان سب الصحابة وانتقاصهم حرية تعبير فإن هذا لا يجوز؛ لأن فيه زعزعة لأصل من أصول الدين التي أمر الشرع بصيانتها.

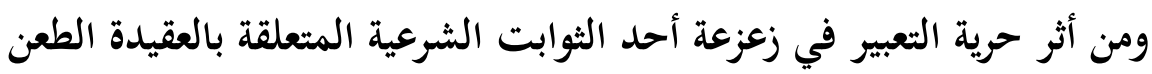
في الشخصيات والرموز الإسلامية التي حملت على عاتقها همَّ الدين وتبليغه لهنه

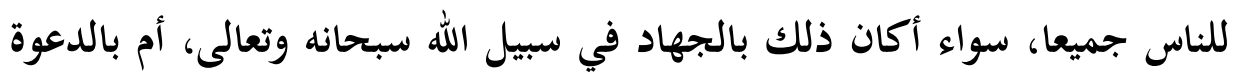

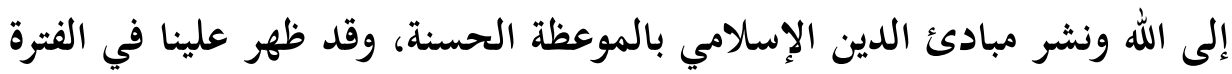

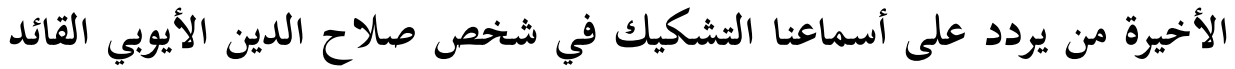
المجاهد الذي حمل همّ الأمة الإسلامية وقام بفرض الكفاية- الجهاد في سبي سبيل

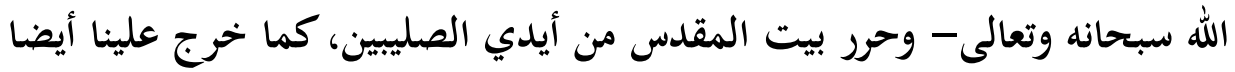
من طعن على إمام من أئمة المسلمين قطع المسافات في شتى بلدان العالم لنبليغ

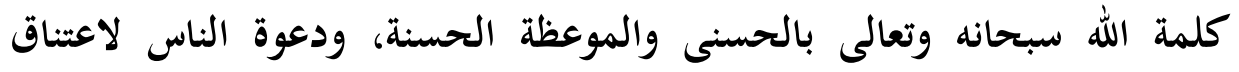

كان من أعلم الناس بككلام العرب وأنسابهم وآبائهم، ولي قضاء سبتة ومولده فيها، روى

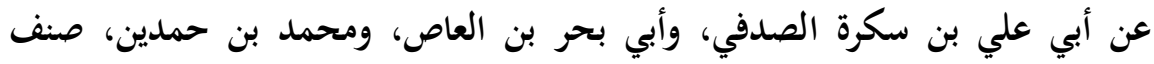

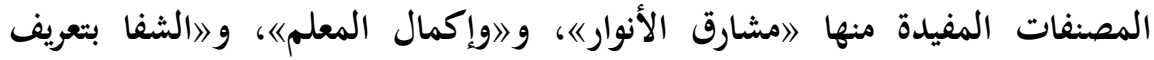
المصطفى،، وغيرها، توفي سنة (544 هـ). ينظر: وفيات الأعيان 3/ 483، وسير

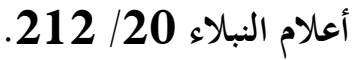
(1) إكمال المعلم بفوائد مسلم، للقاضي عياض بن موسى اليحصبي، تحقيق: الدكتور يحيى

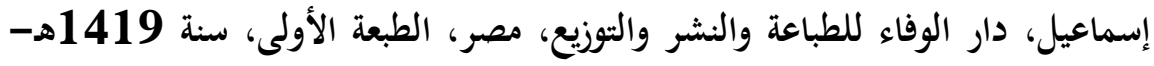

.580/7 1998 
دعاوى حرية التعبير وأثرها فى زعزعة الاستقرار والثوابت

الإسلام، هذا الإمام هو الشيخ محمد متولي الشعراوي رحمه الله تعالى، وكل ذلك التشكيك والطعن اتخذوا له ستارا وحجة تسمى حرية الرأي والتعبير.

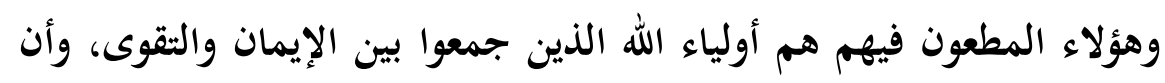

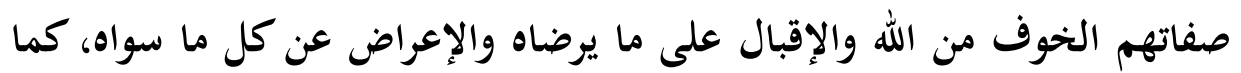
قال الأمير الصنعاني (1). وهؤلاء الطاعنون في أولياء الله وخاصته نسوا قوله سبحانه وتعالى:

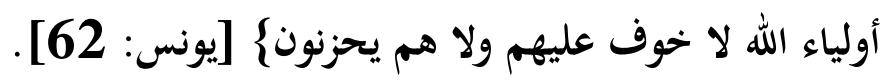

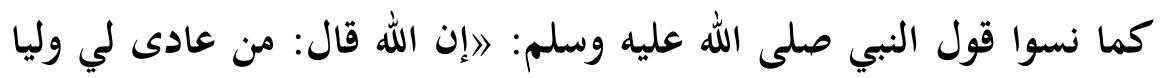
فقد آذنته بالحرب《) (2. قال الحافظ ابن حجر العسقلاني عند شرحه لهذا الحديث: ايقتضي الزجر

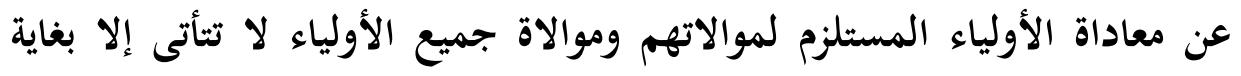

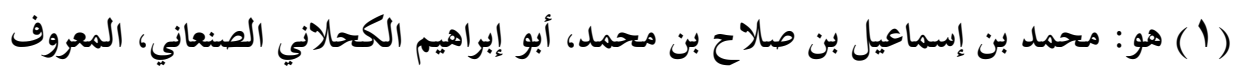

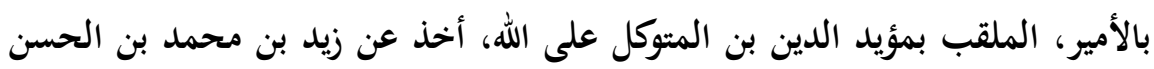

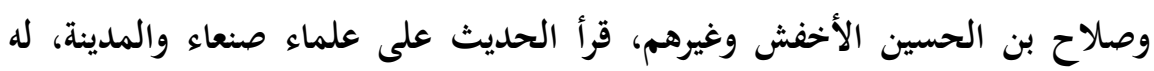

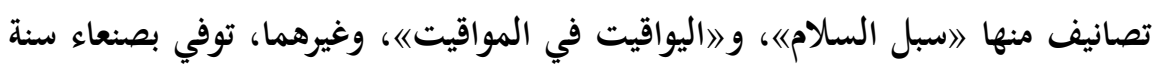

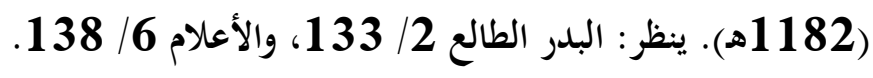

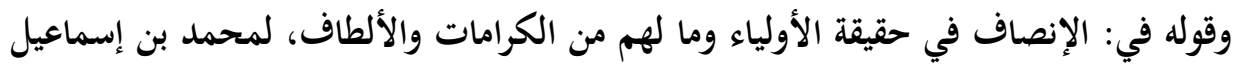

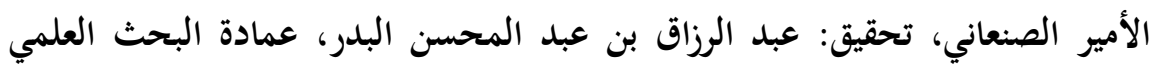
بالجامعة الإسلامية، المدينة المنورة، الطعة الأولى، سنة 1421هـ، ص صل 46، 50. (Y) أخرجه البخاري في صحيحه (6502) من حديث أبي هريرة رضي الله عنه. 
دعاوى حرية التعبير وأثرها فى زعزعة الاستقرار والثوابت

التواضع|"1)

إذن فإن حرية التعبير إن أدت إلى التشكيك أو الطعن في أحد الشخصيات

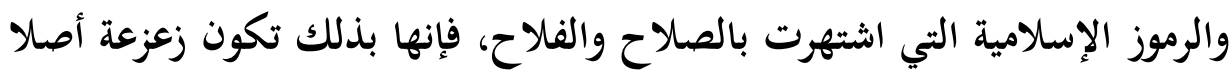

من الأصول التي أكدت النصوص الشرعية على التزامها واحترامها.

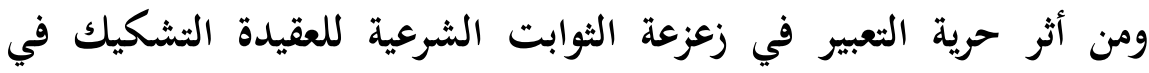

المقدسات الإسلامية والعربية مما يعد شكا في أصول وثوابت تاريخ الأنبياء

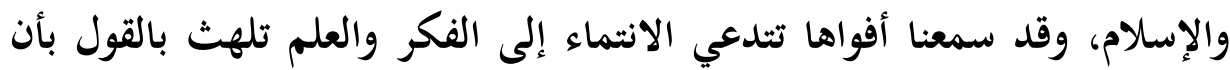
المسجد الأقصى ليس ملكا للمسلمين والعرب ولكنه ملك إسرائيل واليهود، كل ذلك متخذين حرية الرأي والتعبير سندا لتعضيد مقولاتهم الباطلة.

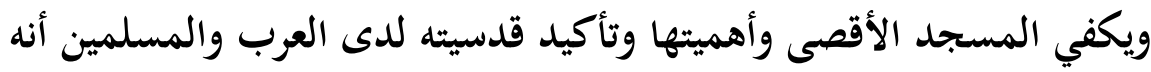
ذكر في القرآن الكريم عند الحديث عن الإسراء والمعراج، فقال سبحانه وتعالى:

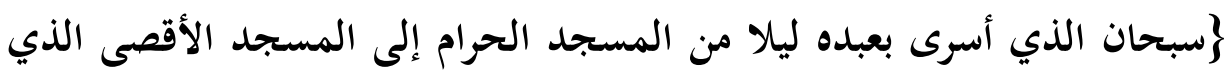
باركنا حوله لنريه من آياتنا إنه هو السميع البصير \{ [الإسراء: 1] ].

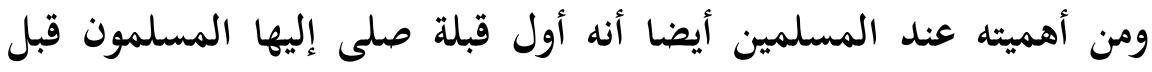
تحويل القبلة إلى المسجد الحرام، كما أنه أحد المساجد التي تشد لها لها الرحال

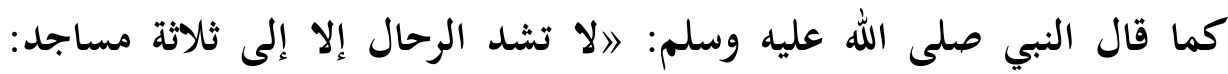
مسجدي هذا، ومسجد الحرام، ومسجد الأقصى" (2.

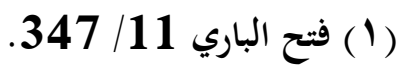
(r) أخرجه البخاري في صحيحه (1189)، ومسلم في صحيحه (1397) من (11) من طريق أبي هريرة رضي الله عنه. 
دعاوى حرية التعبير وأثرها فى زعزعة الاستقرار والثوابت

بيَّنَّا فيما سبق أثر حرية الرأي والتعبير في زعزعة الثوابت الشرعية المتعلقة

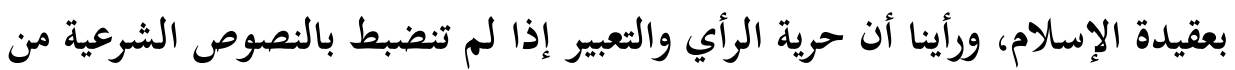
الكتاب والسنة أو خالفتها، فإن ذلك يؤدي إلى زعزعة الثوابت الشرعية لعقيدة التوحيد، فيرتد المسلم عن دينه، وينكر الملحد وجود الله سبحانه وتعالى، وينكر آته

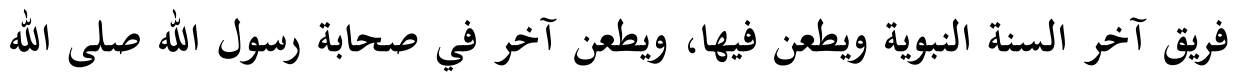

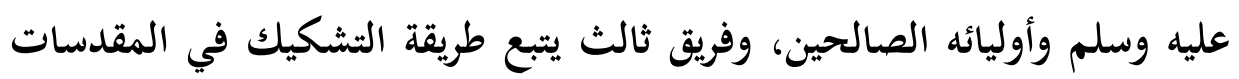
الإسلامية، وكل ذلك تحت غطاء حرية التعبير والرأي.

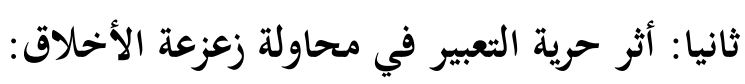

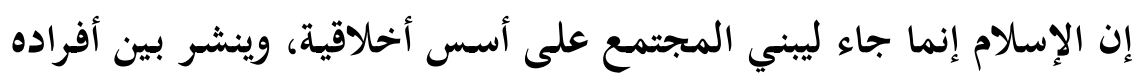

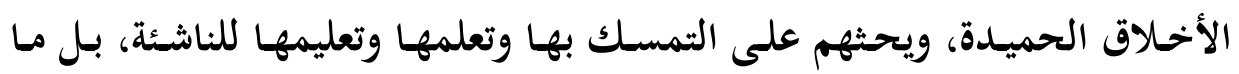

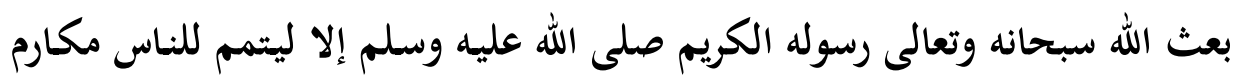
الأخلاق(1)، بل جعل الإسلام حسن الخلق من تمام الإسلام وكماله، فقال النبي

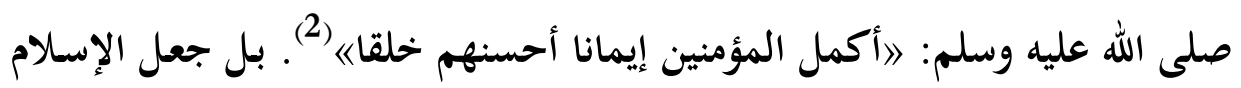

(1) جاء بذلك الخبر عن رسول الله صلى الله عليه وسلم، أخرجه أحمد في مسنده، تحقيق

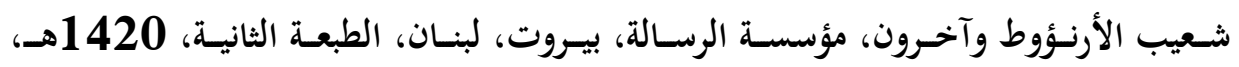

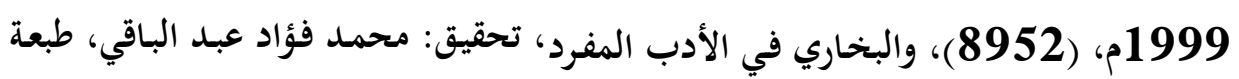

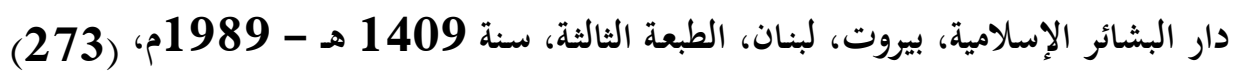
من حديث أبي هريرة رضي الله عنه.

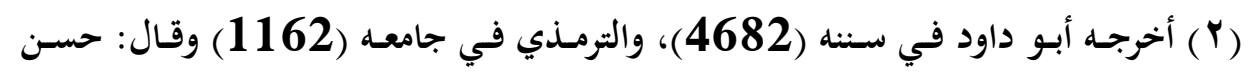
صحيح. من حديث أبي هريرة رضي الله عنه. 
صاحب الخلق الحسن من خيار الناس وأرفعهم في المجتمع، فقد قال النبي صلى النى

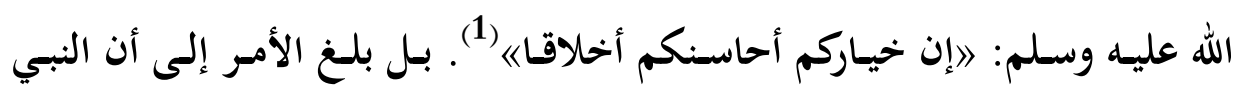

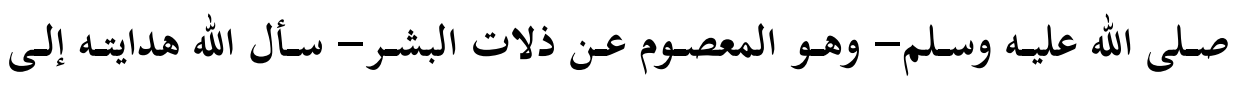
أحسن الأخلاق واستعاذه صلى الله عليه وسلم من سيئها فقال: اواهدنيه ولئ لأحسن

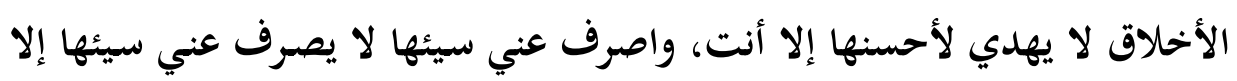
أنت

وجعل الإسلام صاحب الخلق الحسن في درجة عالية يوم القيامة، بل جعله

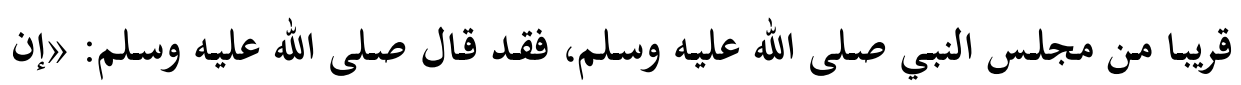
من أحبكم إلي وأقربكم مني مجلسا يوم القيامة أحاسنكم أخلاقاهي (3).

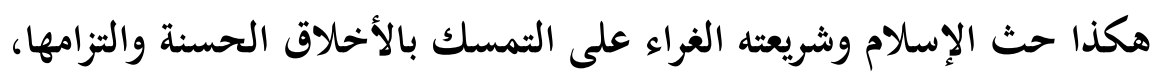

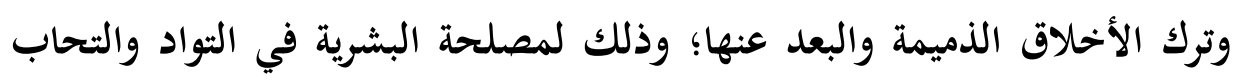

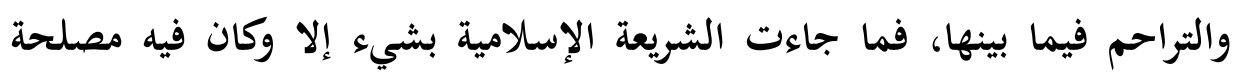
للناس في معاشهم ومعادهم. وأيضا من الأخلاق التي أقرها الإسلام هو التعبير بكل حرية عن الرأي الشخصي في قضية من القضايا، ولكن بضوابطه التي تقدم تفنيدها. ولكن أثر حرية الرأي والتعبير في زعزعة الثوابت الشرعية المتعلقة بالأخلاق

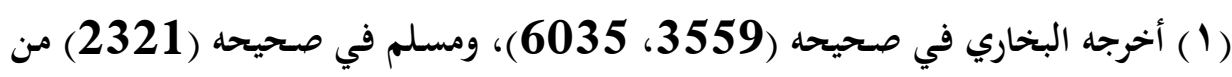
حديث عبد الله بن عمرو رضي الله عنهما.

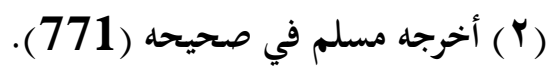

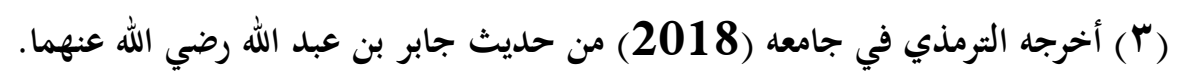


يظهر في الدعوة إلى رذائل الأخلاق ومكارهها، ومن هذه الرذائل دعوة البعض إلى

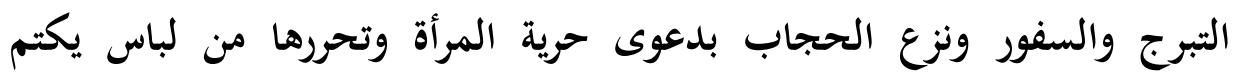

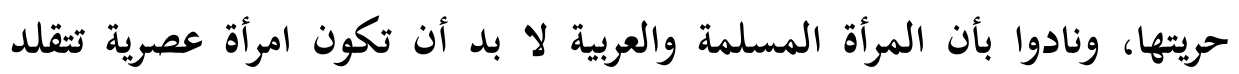

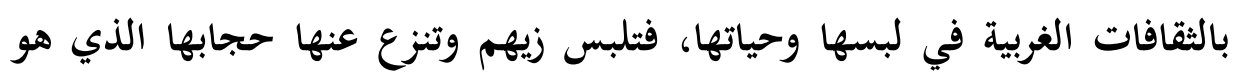
عنوان عفتها وطهارتها.

ولم يقف الأمر عند دعوتهم فقط بل ألفوا كتبا تحمل اسم تحرير المرأة،

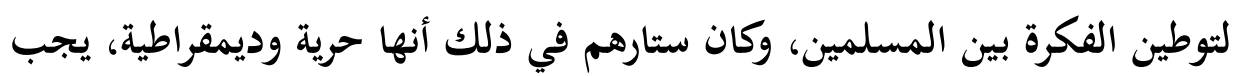

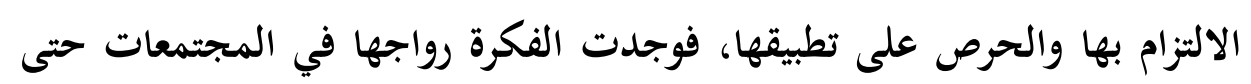

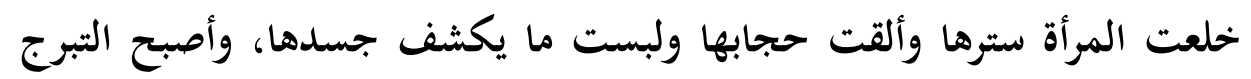

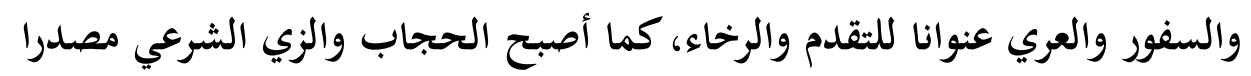
للضحك والسخرية والتخلف والرجعية كما زعموا ورددوا.

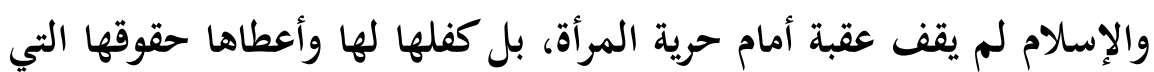
كانت مهدرة في غيرها من الأديان، كحقها في الإرث وغيره، وجعلها درة ثمينة

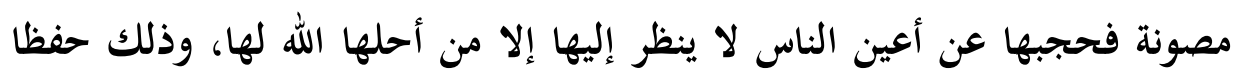
لها وصيانة لعرضها. والحجاب فرض على المرأة المسلمة كما جاءت به النصوص الشرعية، فقد

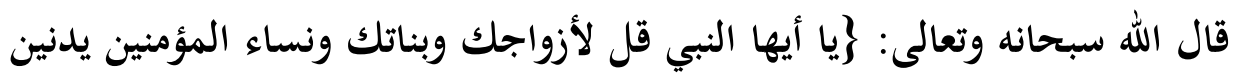
عليهن من جلابيبهن ذلك أدنى أن يعرفن فلا يؤذين وكان الله غفورا رحيما [الأحزاب: 59] 
دعاوى حرية التعبير وأثرها فى زعزعة الاستقرار والثوابت

159

قال أبو بكر الجصاص(1) في تفسير هذه الآية: افي هذه الآية دلالة على أن

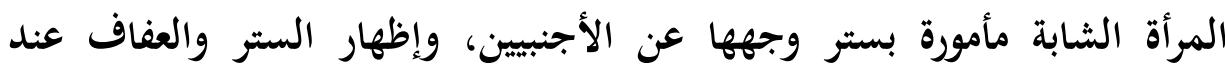
الخروج لئلا يطمع أهل الريب فيهنه (2). هكذا كانت لحرية التعبير والرأي أثرا في زعزعة الثوابت الشرعية المتعلقة بنشر الأخلاق في المجتمعات الإسلامية. ومن أثر حرية التعبير في زعزعة الثوابت الشرعية المتعلقة بالأخلاق، الدعوة الدانهان

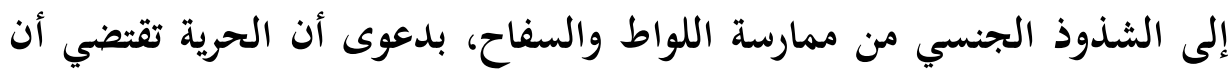

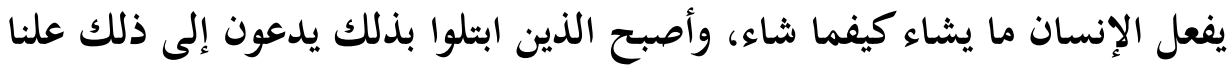

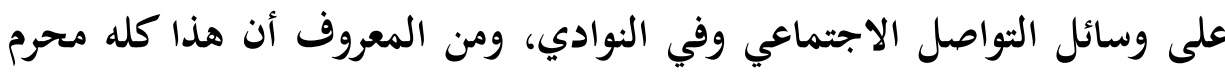

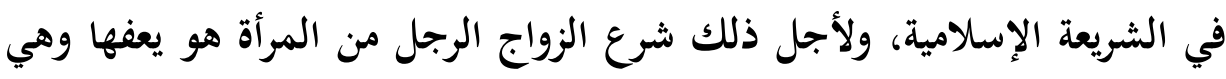
تعفه.

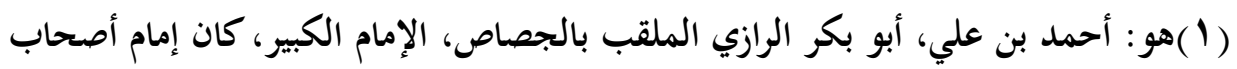

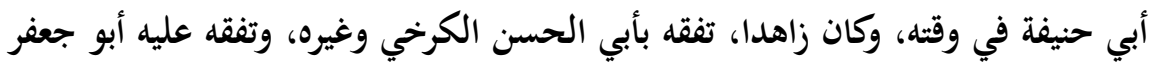

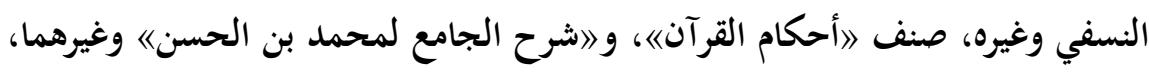

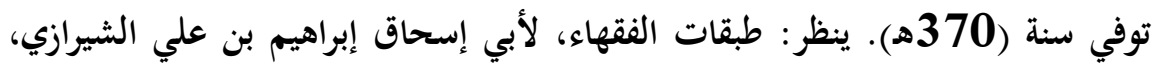

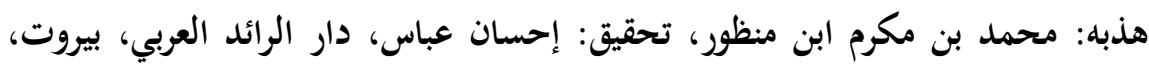

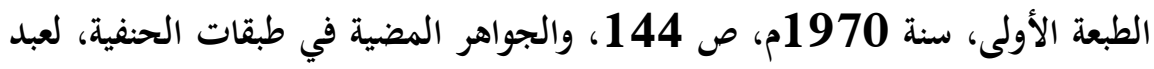

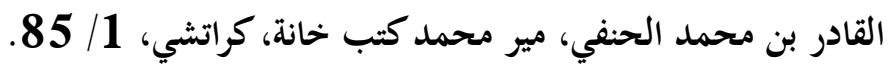

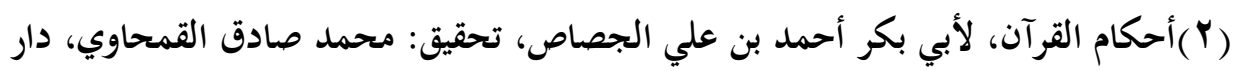

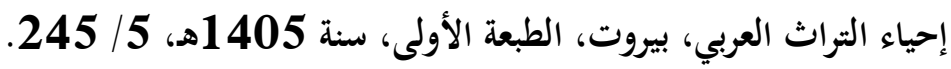


واللواط محرم في الشريعة الإسلامية بنص الكتاب والسنة وإجماع علماء

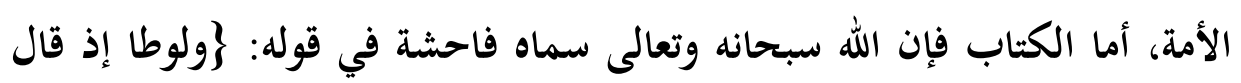
لقومه أتأتون الفاحشة ما سبقكم بها من أحد من العالمين (80) إنكم لتأتون

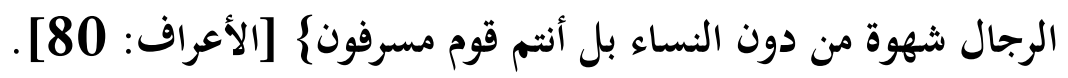

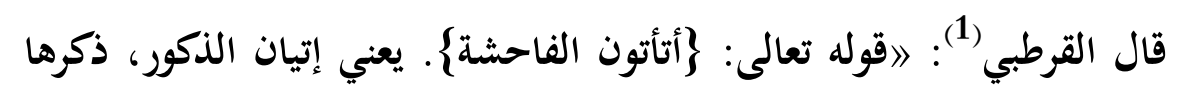

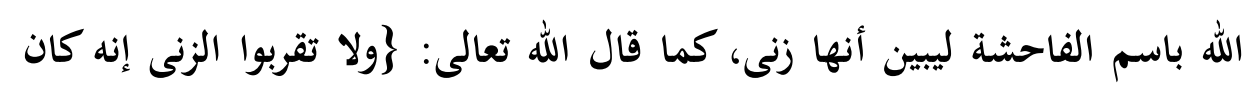

$$
\text { فاحشة [الإسراء: 32] }{ }^{2}
$$

وأما السنة فإنه لبيان شدة الحرمة فقد أمر النبي صلى الله عليه وسلم مرتكب هذا الفعل فقال: 》من وجدتموه يعمل عمل قوم لوط فاقتلوا الفاعل والمفعول

(1) (1) : محمد بن أحمد بن أبي بكر بن فرح الأنصاري الخزرجي الأندلسي، أبو عبد الله

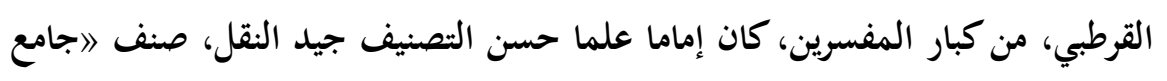

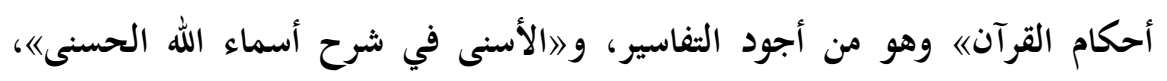

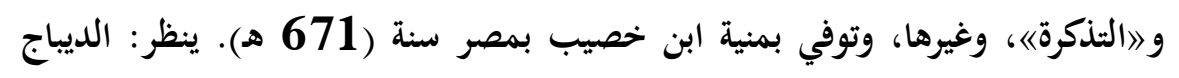

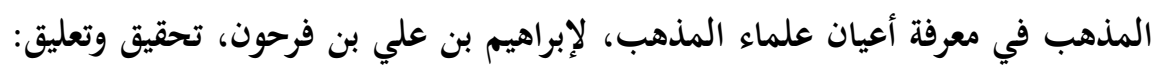

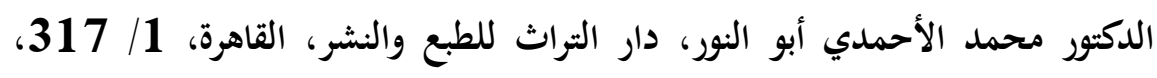
ونفح الطيب من غصن الأندلس الرطيب، لأحمد بن محمد المقري التلمساني، تحقيق:

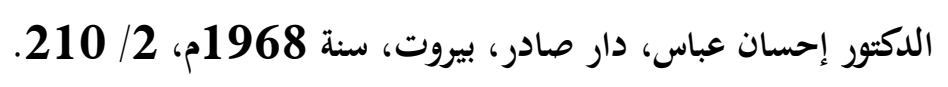

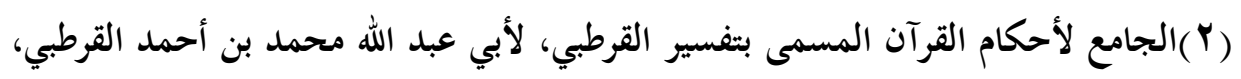
تحقيق: أحمد البردوني وإبراهيم أطفيش، دار الكتب المصرئ المرية، القاهرة، الطبعة الثانية،

$$
\text { سنة 1384هـ- 1964م، } 7 \text { / } 243 .
$$


دعاوى حرية التعبير وأثرها فى زعزعة الاستقرار والثوابت

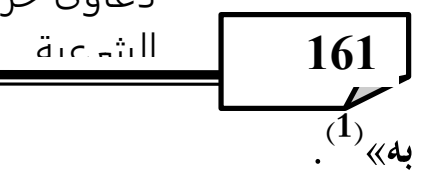

وقد كان تحريم اللواط إجماعا من علماء الأمة، فقد قال ابن هبيرة(2):

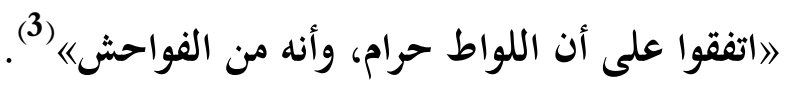

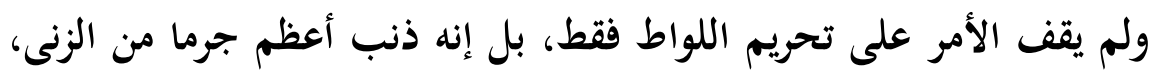

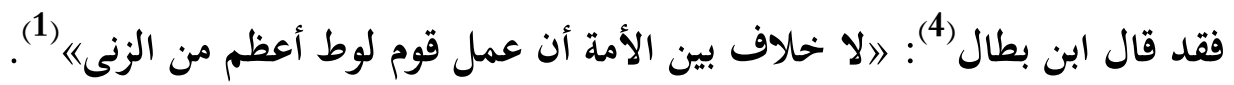

(1) (أخرجه أبو داود في سننه (4462)، والترمذي في جامعه (1456)، وابن ماجه في سننه (2561) من حديث ابن عباس رضي الله عنهما.

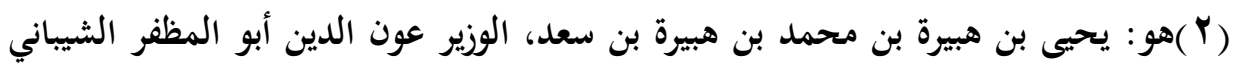

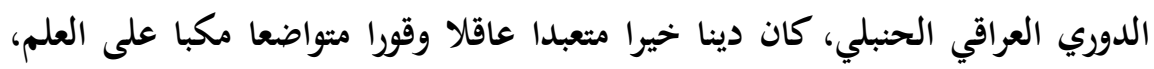

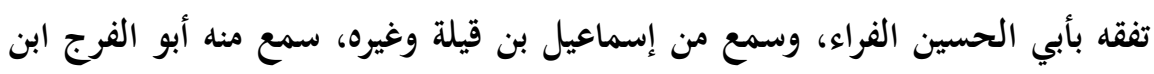

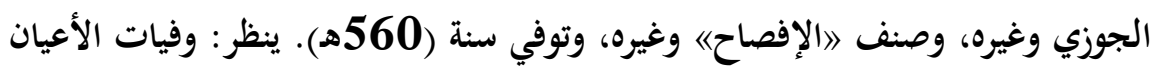

\section{0/6 230، وسير أعلام النبلاء 20/ 426.}

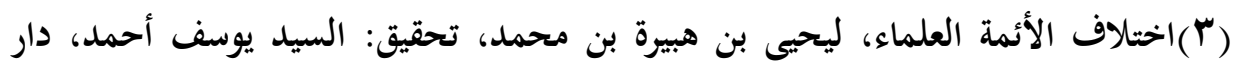

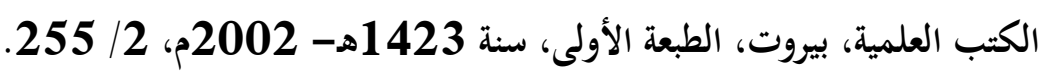

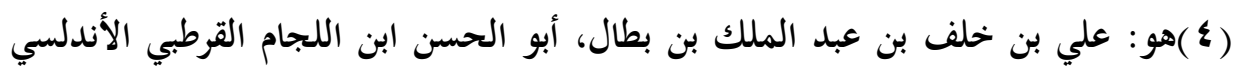

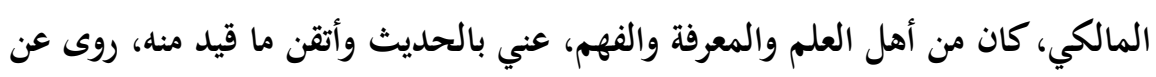

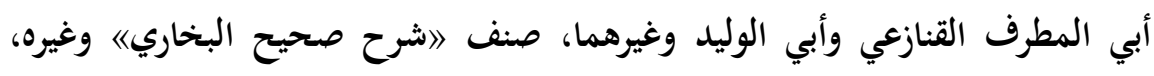

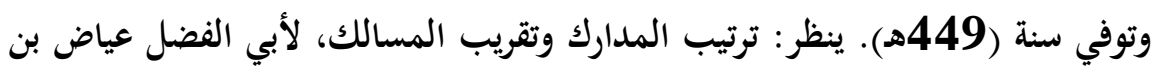

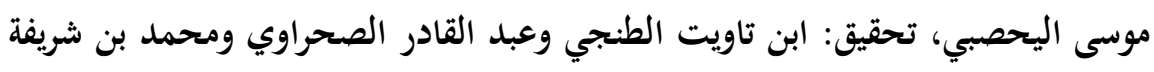

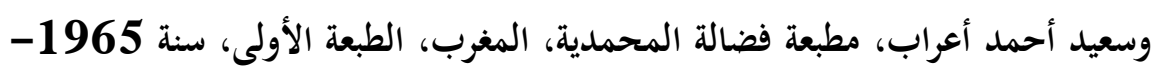

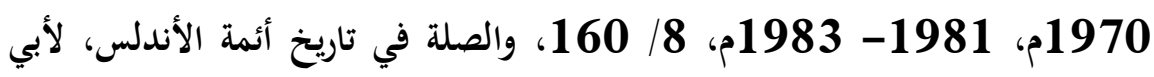


والسفاح كاللواط في حرمته وكلاهما نوع من الشذوذ الذي يخالف فيه

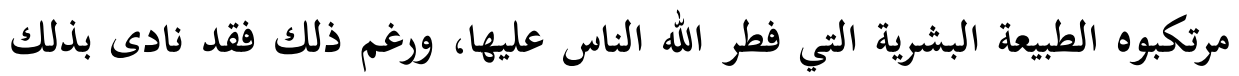

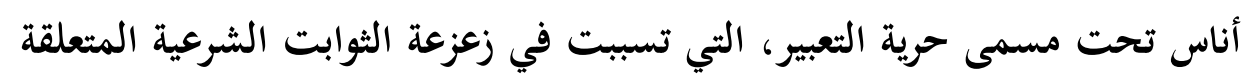

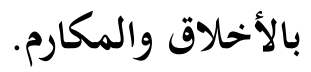

قد بينا فيما سبق أثر حرية التعبير في محاولة زعزعة الثوابت الشرعية التي

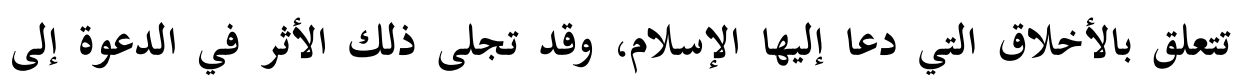

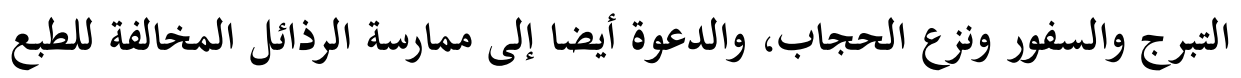

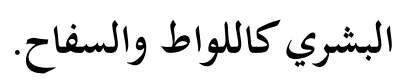

ثالثا: أثر حرية الثعبير في محاولة زعزعة الأحكام الشرعية والفقهية: لثال

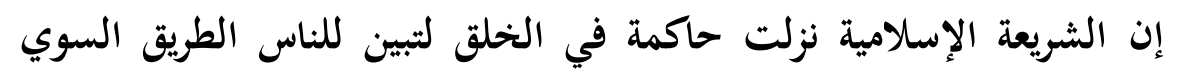

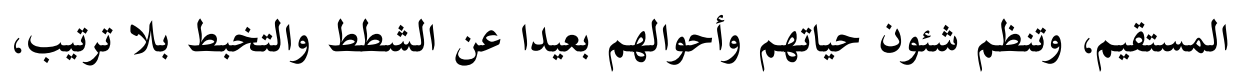

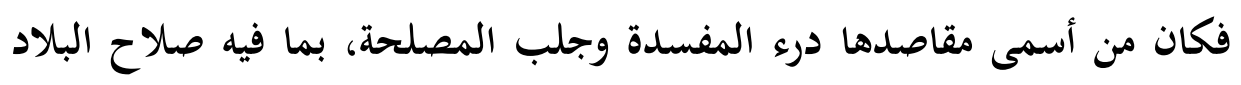

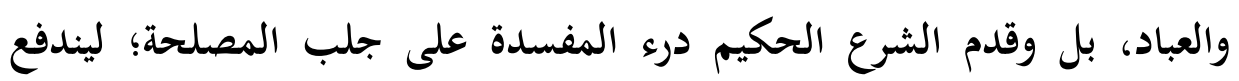

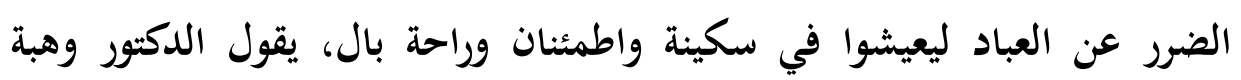
الزحلي: اولا شك بأن أحكام الشريعة تتطلب إقامة مجتمع إسلامي متكامل في

القاسم خلف بن عبد الملك بن بشكوال، عني بنشره وصححه وراجع أصله: السيد

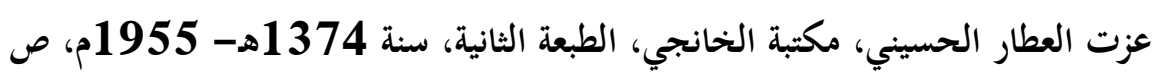
.394

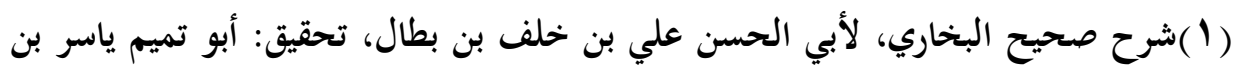

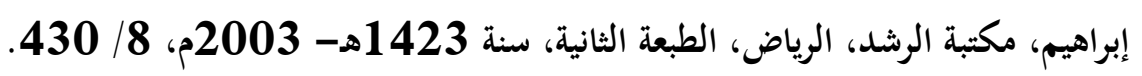


العقيدة والعبادة والسلوك الأخلاقي، وينبغي أن تتجه أنظمة الدولة الدستورية

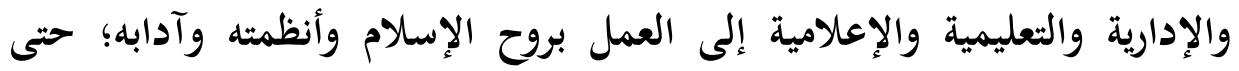
يسهل تقبل الحكم الشرعي الإلهي عن عقيدة واقتناع وحب واحترام《 (1).

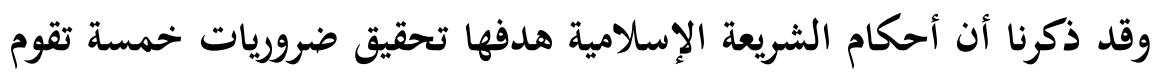
عليها الحياة البشرية، تلك الضروريات هي حفظ الدين وحفظ النفس وحفظ العقل وحفظ المال وحفظ النسب والنسل والعرض، وشرعت عقوبات زاجرة لتحقيق تلك الضروريات (2).

والأحكام الشرعية في الفقه الإسلامي تنقسم إلى أحكام فقهية تتعلق

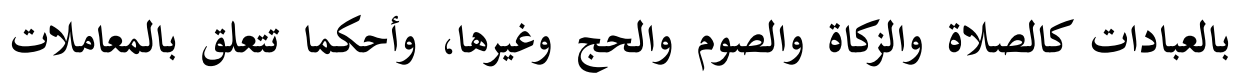

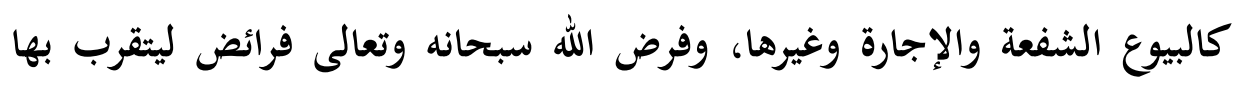
إليه، وحرم أشياء ليبتعد الناس عنها تقربا إليه.

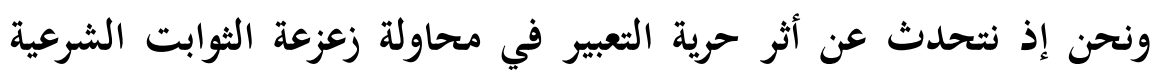

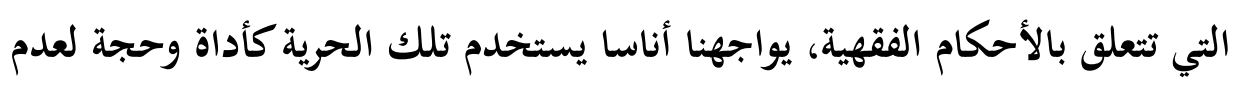

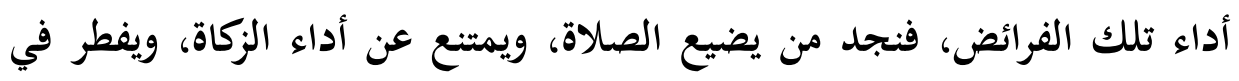

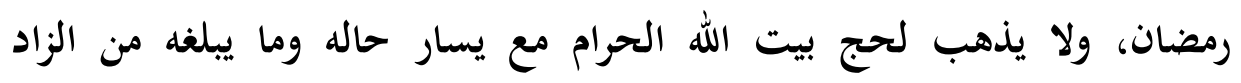
والراحلة، ويعتبرون ذلك حرية وتعبيرا عن رأي.

(1) الفقه الإسلامي وأدلثه(الشامل للأدلة الشرعية والآراء المذهبية وأهم النظريات الفقهية

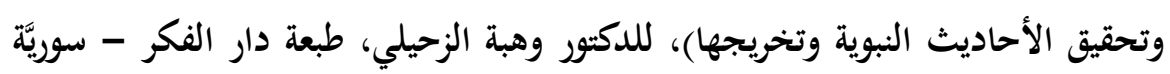

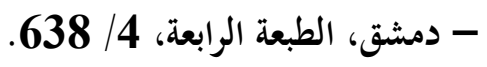

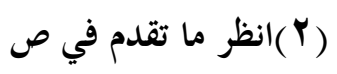


دعاوى حرية التعبير وأثرها فى زعزعة الاستقرار والثوابت

وهذا الأمر مذموم شرعا لا يقبله الشارع ولا يمدحه؛ لأن الإنسان مأمور

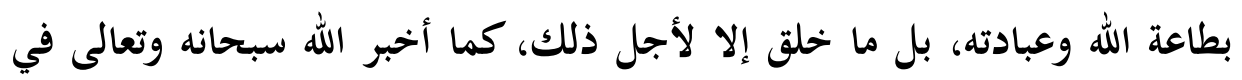
كتابه الكريم بقوله: \}وما خلقت الجن والإنس إلا ليعبدون (56) ما أريد منهم من إلن

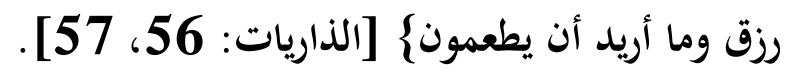
وقال أيضا: زوما أمروا إلا ليعبدوا الله مخلصين له الداندان الدين حنفاء ويقيموا

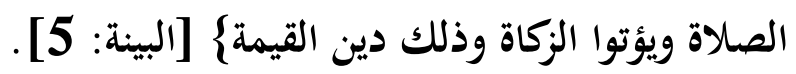

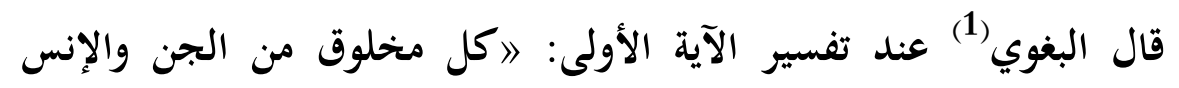
خاضع لقضاء الله، متذلل لمشيئه لا يملك أحد لنفسه خروجا عما خلق عليهه (2).

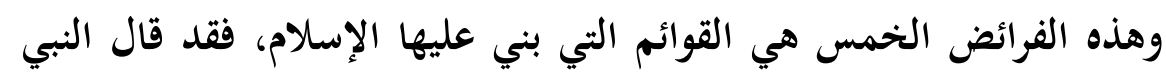

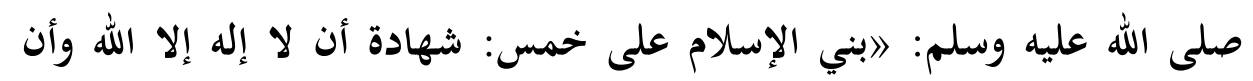

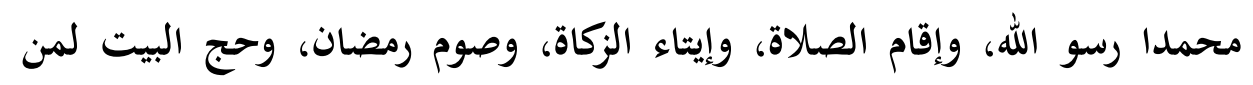

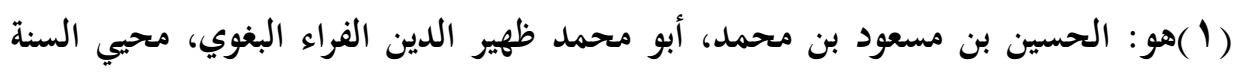

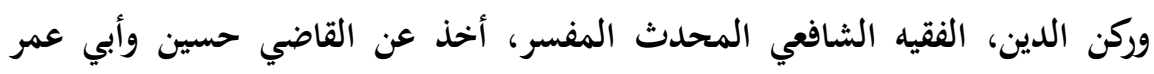

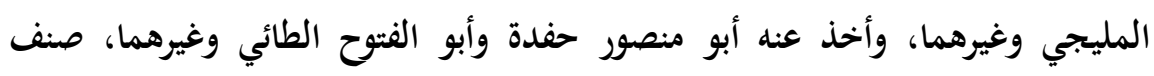
》التهذيب《، و (مصابيح السنة) وغيرهما، وتوفي سنة (510هـ) وقيل: (516هـهـ.

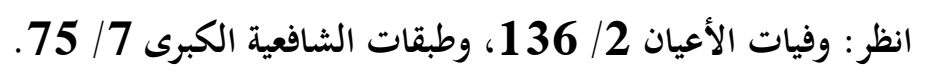

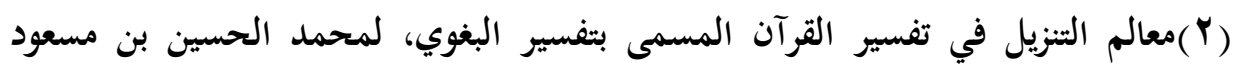

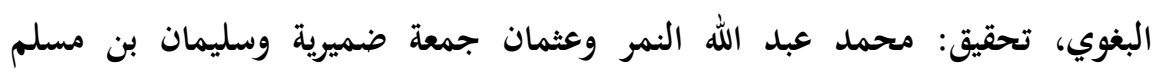

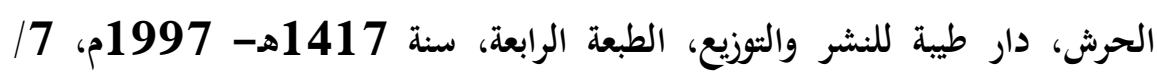


دعاوى حرية التعبير وأثرها فى زعزعة الاستقرار والثوابت

استطاع إليه سبيلاپ《).

من هنا تبين أن لحرية الرأي الأثر في محاولة زعزعة الثوابت الثرعية التي

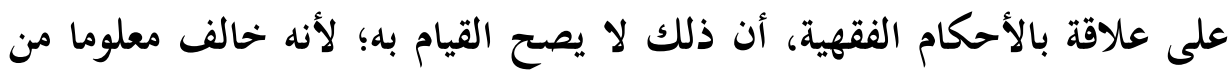

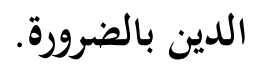

مما سبق يتضح أثر حرية التعبير في زعزعة الثوابت الشرعية التي تتعلق بالعقيدة والأخلاق والأحكام الفقهية.

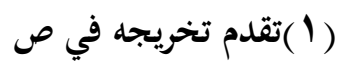


دعاوى حرية التعبير وأثرها فى زعزعة الاستقرار والثوابت

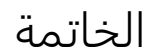

الحمد لله والصلاة والسلام على رسول الله صلى الله عليه وسلم وآله وصحبه

بعد أن اطلعنا على حرية التعبير وأثرها في زعزعة الثوابت الشرعية، أحاول أن

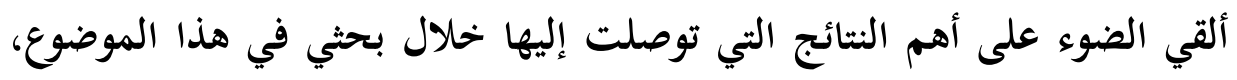

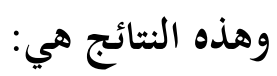

1- الشريعة الإسلامية جاءت أحكامها لجلب المصالح للناس ودرء المفاسد

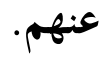

2- كفلت الشريعة الإسلامية حرية التعبير والرأي للناس جميعا، وأقره حتى

في اعتناق الإسلام نفسه.

3- لا بد من توافر ستة ضوابط لحرية التعبير في الشريعة الإسلامية، هذه

الضوابط هي: - الض

أ- أن يكون الرأي موافقا لأحكام الشريعة مقيدا بنصوصها.

ب- أن يكون التعبير عن الرأي بالخير الذي يعم الناس ويقضي حوائجهم.

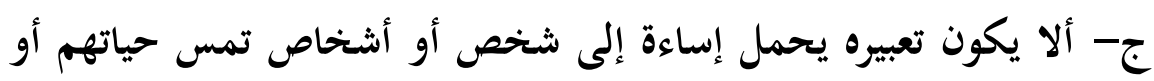

أعراضهم أو سمعتهم أو مكانتهم.

د- أن يكون الرأي متسما بالإنصاف والعدل واحترام الآخر.

هـ أن يكون الرأي من منطلق المحافظة على أمن المجتمع واستقراره.

و - على الإنسان عند إبداء رأيه أن يفرق بين النقد والتشهير.

4- للضروريات الخمسة المقاصدية- حفظ الدين والنفس والعقل والمال

مجلة كلية البنات الأزهرية بطيبة الجديدة ـ بالأقصر

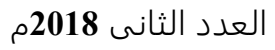


دعاوى حرية التعبير وأثرها فى زعزعة الاستقرار والثوابت

$$
\text { والنسل والنسب والعرض- أثر في حرية الرأي والتعبير. }
$$

5- لحرية التعبير والرأي الأثر في زعزعة الثوابت الشرعية المتعلقة بعقيدة

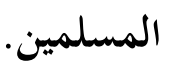

6- لحرية التعبير والرأي الأثر في زعزعة الثوابت الشرعية المتعلقة بالأخلاق ومكارمها.

7- لحرية التعبير والرأي الأثر في زعزعة الثوابت الشرعية المتعلقة بالأحكام

الشرعية والفقهية المختلفة.

$$
\text { التوصيات: }
$$

بعد طوفنا بالبحث والدراسة في موضوع دعاوى حرية التعبير وأثرها في زعزعة

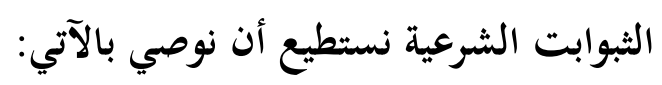

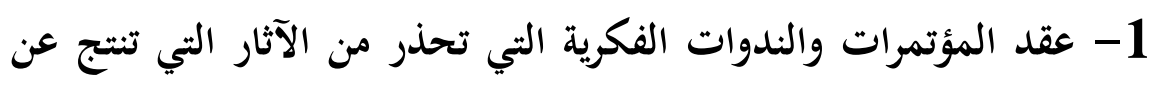

$$
\text { زعزعة حرية التعبير للثوابت الشرعية. }
$$

2- تشديد الرقابة على وسائل الإعلام المسموعة والمرئية والمقروءة للحد

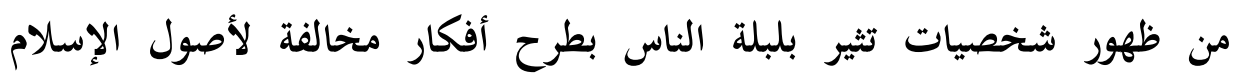
وأحكامه.

3- تنمية الوعي الثقافي والديني في نفوس الناشئة عن طريق تعليمهم التمييز بين ما هو محمود وما هو مذموم. وصلى الله على محمد وعلى آله وصحبه وسلم تسليما كثيرا. 
دعاوى حرية التعبير وأثرها فى زعزعة الاستقرار والثوابت

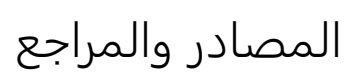

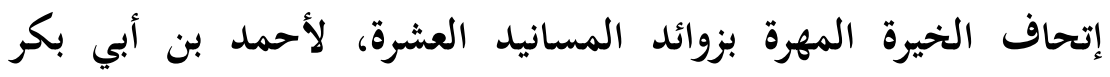

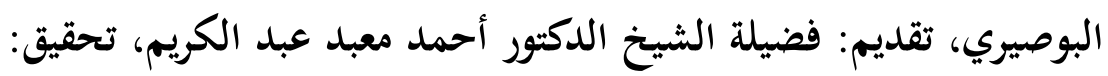

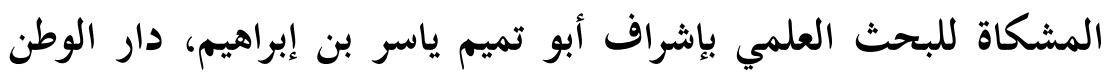
للنشر، الرياض، الطبعة الأولى، سنة 1420هـ- لإلـ 1999م.

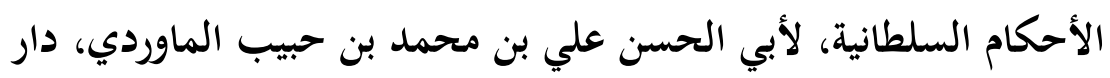

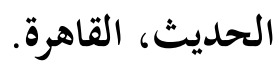
أحكام القرآن، لأبي بكر أحمد بن علي الجصاص، تحقيق: محمد صادق الجداف

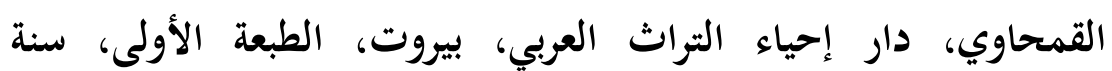

\section{5هـ}

اختلاف الأئمة العلماء، ليحيى بن هبيرة بن محمد، تحقيق: السيد يوسف أحمد، دار الكتب العلمية، بيروت، الطبعة الأولى، سنة 1423هـ-

2002

الأدب المفرد، لمحمد بن إسماعيل البخاري، تحقيق: محمد فؤاد عبد الباقي، طبعة دار البشائر الإسلامية، بيروت، لبنان، الطبعة الثالثة، سنة

$$
1409 \text { هـ - 1989 1989. }
$$

أصول الفقه الإسلامي، للدكتور وهبة الزحيلي، دار الفكر للطباعة والنشر،

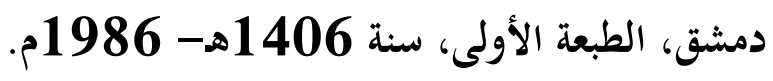

إعلام الموقعين عن رب العالمين، لابن قيم الجوزية، تقديم وتخريج: أبو لإنها

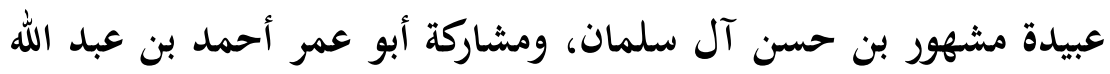


دعاوى حرية التعبير وأثرها فى زعزعة الاستقرار والثوابت

أحمد، دار ابن الجوزي للنشر والتوزيع، السعودية، الطبعة الأولى، سنة

الأعلام، لخير الدين بن محمود الزركلي، دار العلم للملايين، الطبعة الخامسة عشر، سنة 2002م.

إكمال المعلم بفوائد مسلم، للقاضي عياض بن موسى اليحصبي، تحقيق:

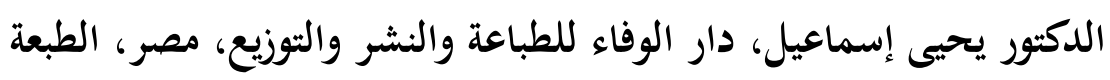

$$
\text { الأولى، سنة 1419هـ- 1998م. }
$$

الإنصاف في حقيقة الأولياء وما لهم من الكرامات والألطاف، لمحمد بن لهن

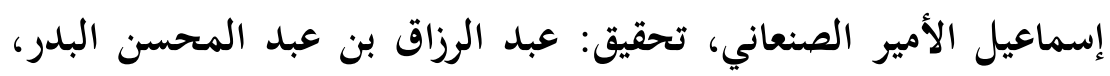

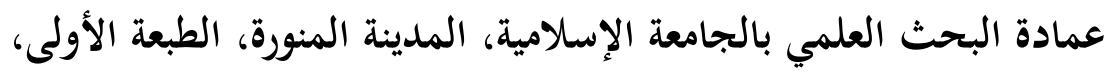

سنة 1421هـ.

بحث حرية التعبير عن الرأي في الشريعة الإسلامية التأصيل والضوابط،

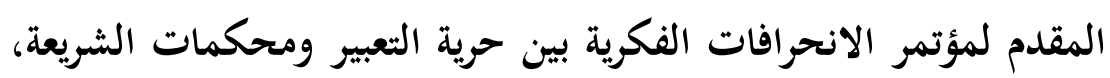

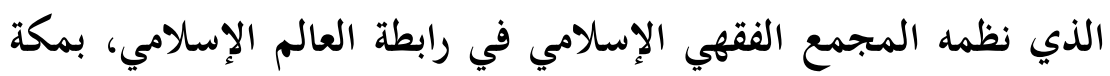
المكرمة، إعداد عبد الله عبد العزيز الزايدي.

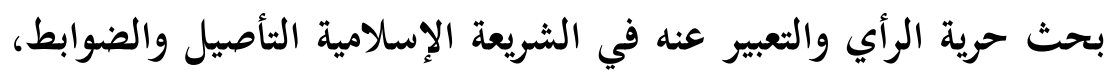

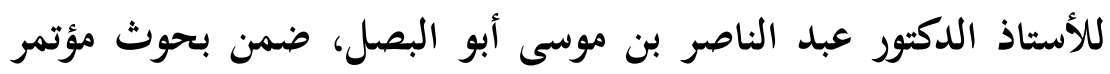
الانحرافات الفكرية بين حرية التعبير ومحكمات الشريعة.

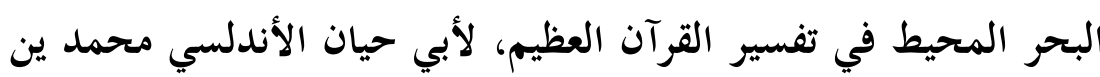

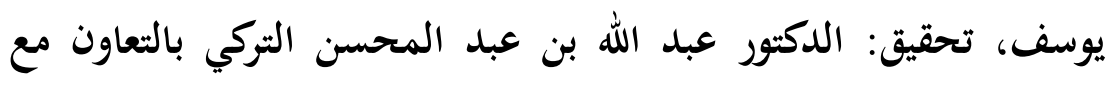


دعاوى حرية التعبير وأثرها فى زعزعة الاستقرار والثوابت

مركز هجر للبحوث والدراسات العربية والإسلامية، دار هجر للنشر

والإعلان، القاهرة، الطبعة الأولى، سنة 1436هـ- 2015م.

البدر الطالع بمحاسن من بعد القرن السابع، لمحمد بن علي الثوكاني،

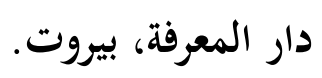

تاج العروس من جواهر القاموس، لمحمد بن محمد المرتضى الزبيدي، دار الهداية.

تاريخ بغداد، لأبي بكر أحمد بن علي الخطيب البغدادي، تحقيق: الدكتور بشار عواد معروف، دار الفرب الإسلامي، بيروت، الطبعة الأولى، سنة

2002- 1422

تأويل مختلف الحديث، لأبي محمد عبد الله بن مسلم بن قتيبة، المكتب الإسلامي، مؤسسة الإشراق، الطبعة الثانية، سنة 1419هـ- 1999م. ترتيب المدارك وتقريب المسالك، لأبي الفضل عياض بن موسى اليحصبي، تحقيق: ابن تاويت الطنجي وعبد القادر الصحراوي ومحمد بن

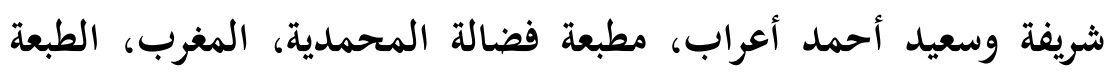

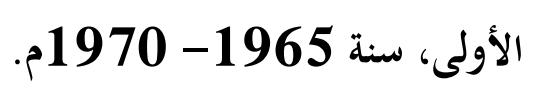

التعريفات الفقهية، لمحمد عميم الإحسان البركتي، دار الكتب العلمية،

بيروت، الطبعة الأولى، سنة 1424هـ الطئ 2003م.

التفسير البسيط، لأبي الحسن علي بن أحمد الواحدي، تحقيق: لجنة علمية من جامعة الإمام محمد بن سعود، نشر عمادة البحث العلمي بجامعة الإمام محمد بن سعود الإسلامية، الطبعة الأولى، سنة 1430هـ. 
دعاوى حرية التعبير وأثرها فى زعزعة الاستقرار والثوابت

تفسير التستري، لأبي محمد سهل بن عبد الله التستري، جمعها: أبو بكر

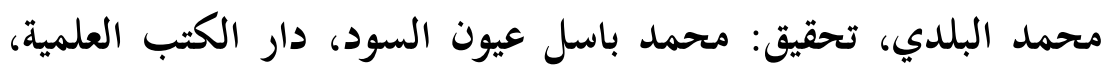
بيروت، الطبعة الأولى، سنة 1423هـ.

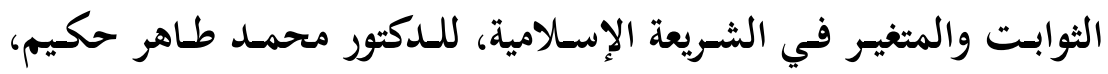

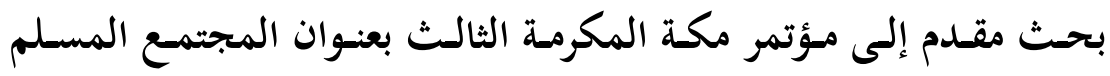
الثوابـت والمتغيـرات، الـذي تنظمسه رابطـة العـالم الإسـالامي، 4- 5 ذو دو الحجة 1432هـ- 20- 21 أكتوبر 2012م.

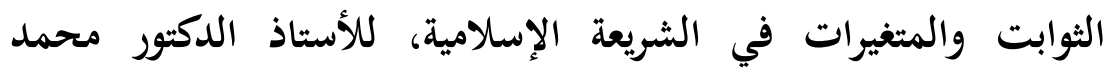

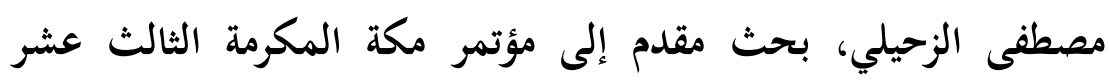
بعنوان المجتمع المسلم الثوابت والمتغيرات، الذي تنظمه رابطة العالم الإسلامي، 4- 5 ذو الحجة 1432هـ- 20- 21 أكتوبر 2012م. جامع البيان عن تأويل آي القرآن، لمحمد بن جرير الطبري، تحقيق:

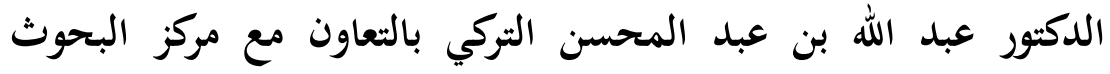

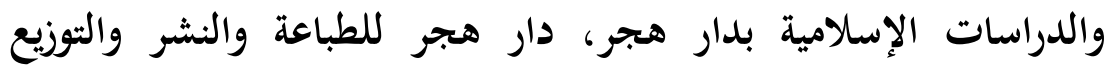
والإعلان، الطبعة الأولى، سنة 1422هـ- 2001م.

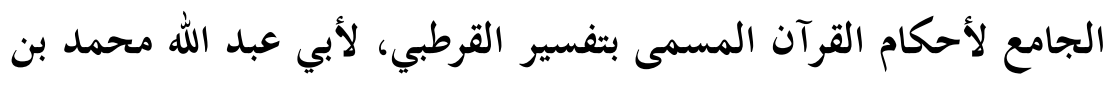

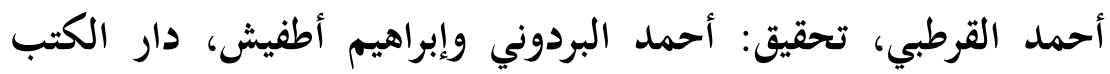
المصرية، القاهرة، الطبعة الثانية، سنة 1384هـ- 1964م.

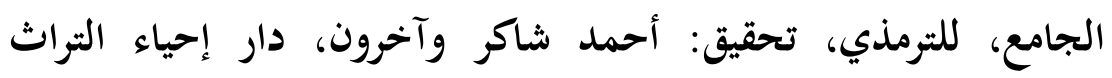

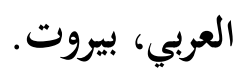


دعاوى حرية التعبير وأثرها فى زعزعة الاستقرار والثوابت

الجواهر المضية في طبقات الحنفية، لعبد القادر بن محمد الحنفي، مير

$$
\text { محمد كتب خانة، كراتشي. }
$$

حرية الرأي والتعبير في التشريع الإسلامي، للدكتور معاوية أحمد سيد أحمد، بحث منشور بمجلة الشريعة والدراسات الإسلامية، العدد 13، صفر 1430هـ- فبراير 2009م. حرية الرأي والتعبير في الشريعة الإسلامية التأصيل والضوابط، للشيخ

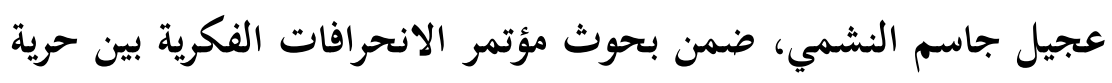
التعبير ومحكمات الشريعة، الذي نظمه المجمع الفقهي الإسلامي، التابع لرابطة العالم الإسلامي بمكة المكرمة.

حقوق الإنسان في الإسلام والرد على الشبهات المثارة حولها، لسليمان بن عبد الرحمن الحقيل، طبع على نفقة صالح السمو الملكي الأمير سلطان بن عبد العزيز آل سعود، الرياض، الطبعة الرابعة، سنة 1424هـ2003

الدرر الكامنة في أعيان المائة الثامنة، لأبي الفضل أحمد بن علي بن

$$
\text { حجر العسقلاني، دار الجيل، بيروت. }
$$

الديباج المذهب في معرفة أعيان علماء المذهب، لإبراهيم بن علي بن فرحون، تحقيق وتعليق: الدكتور محمد الأحمدي أبو النور، دار التراث

$$
\text { للطبع والنشر، القاهرة. }
$$

ذيل الثقييد في رواة السنن والأسانيد، لمحمد بن أحمد الفاسي، تحقيق: كمال يوسف الحوت، دار الكتب العلمية، بيروت، الطبعة الأولى، سنة 


\section{0هـ}

ذيل طبقات الحنابلة، لعبد الرحمن بن أحمد بن رجب الحنبلي، تحقيق:

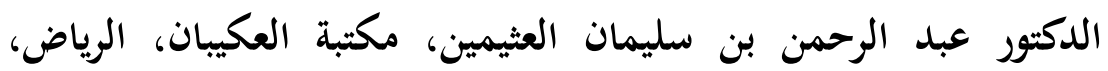

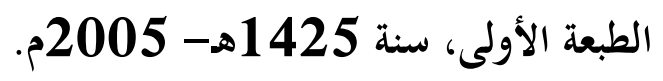

سنن ابن ماجه، لمحمد ين يزيد القزويني ابن ماجه، تحقيق: محمد فؤاد الداد

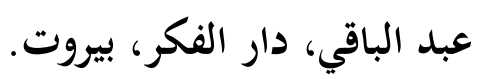

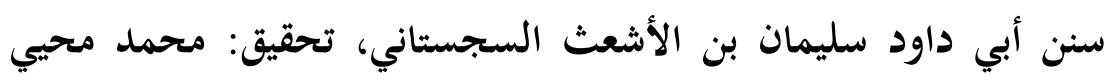
الدين عبد الحميد، دار الفكر، بيروت. سير أعلام النبلاء، لشمس الدين الذهبي، مؤسسة الرسالة، الطبعة الثالثة، سنة 1405 هـ، 1985م. الشافي في شرح مسند الشافعي، لمجد الدين أبي السعادات المبارك بن

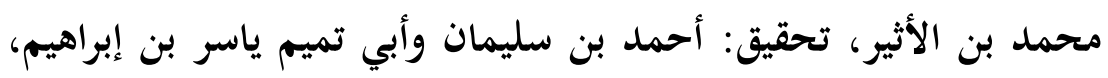

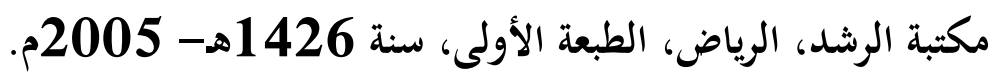

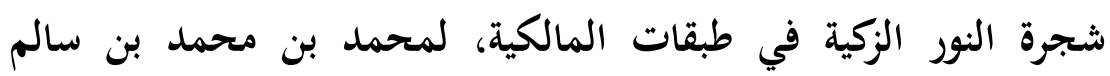

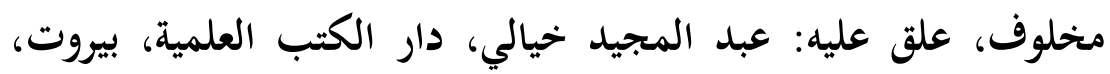
الطبعة الأولى، سنة 1424هـ- 2003م. شذرات الذهب في أخبار من ذهب، لعبد الحي بن أحمد ابن العماد

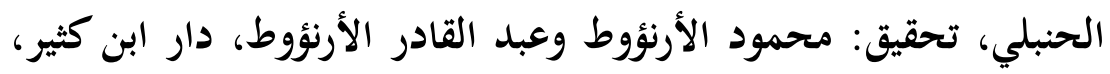

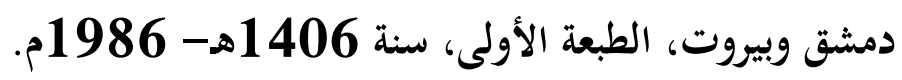
شرح صحيح البخاري، لأبي الحسن علي بن خلف بن بطال، تحقيق: أبو 
دعاوى حرية التعبير وأثرها فى زعزعة الاستقرار والثوابت

تميم ياسر بن إبراهيم، مكتبة الرشد، الرياض، الطبعة الثانية، سنة

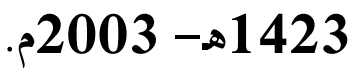

الشرك في القديم والحديث، لأبي بكر محمد زكريا، مكتبة الرشد، الرياض، الطبعة الأولى، سنة 1422هـ- 2001م.

الصحاح تاج اللغة وصحاح العربية، لأبي نصر إسماعيل بن حماد الجوهري، تحقيق: أحمد عبد الغفور عطار، دار العلم للملايين، بيروت،

الطبعة الرابعة، سنة 407 1ــ 1987م.

صحيح البخاري المسمى بالجامع الصحيح المختصر من أمور رسول الله صلى الله عليه وسلم وسننه وأيامه، لمحمد بن إسماعيل البخاري، تحقيق: محمد زهير بن ناصر الناصر، دار طوق النجاة، الطبعة الأولى، سنة

$\$ 1422$

صحيح مسلم المسمى المسند الصحيح المختصر بنقل العدل إلى رسول

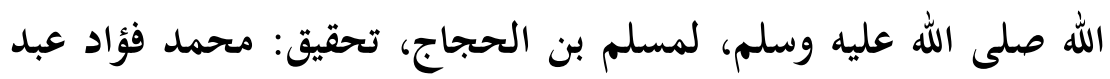
الباقي، دار إحياء التراث العربي، بيروت.

الصلة في تاريخ أئمة الأندلس، لأبي القاسم خحلف بن عبد الملك بن بشكوال، عني بنشره وصححه وراجع أصله: السيد عزت العطار الحسيني، مكتبة الخانجي، الطبعة الثانية، سنة 1374هـ- 1955م. طبقات الحفاظ، لعبد الرحمن بن أبي بكر السيوطي، دار الكتب العلمية، بيروت، الطبعة الأولى، سنة 403 هـ. طبقات الشافعية الكبرى، لتاج الدين السبكي، تحقيق: الدكتور محمود 
دعاوى حرية التعبير وأثرها فى زعزعة الاستقرار والثوابت

محمد الطناحي والدكتور عبد الفتاح محمد الحلو، هجر للطباعة والنشر

والثوزيع، الطبعة الثانية، سنة 1413 هـ.

طبقات الشافعية، لعبد الرحيم بن الحسن الإسنوي، تحقيق: كمال يوسف

الحوت، دار الكتب العلمية، بيروت، الطبعة الأولى، سنة 2002م.

طبقات الثافعيين، لأبي الفداء إسماعيل بن عمر بن كثير، تحقيق: الدكتور أحمد عمر هاشم والدكتور محمد زينهم محمد عزب، مكتبة

الثقافة الدينية، القاهرة، سنة 1413هـ- 1993 1م.

طبقات الصوفية، لأبي عبد الرحمن محمد بن الحسين السلمي، تحقيق: مصطفى عبد القادر عطا، دار الكتب العلمية، بيروت، الطبعة الأولى، سنة

1998- 1419

طبقات الفقهاء، لأبي إسحاق إبراهيم بن علي الثيرازي، هذبه: محمد بن مكرم ابن منظور، تحقيق: إحسان عباس، دار الرائد العبي، بيروت،

$$
\text { الطبعة الأولى، سنة 1970م. }
$$

عارضة الأحوذي، لأبي بكر ابن العببي، دار الكتب العلمية، بيروت.

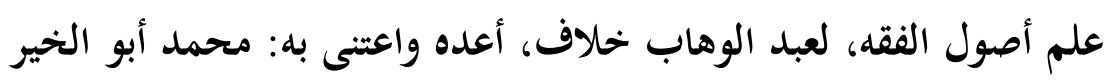
السيد، مؤسسة الرسالة ناشرون، بيروت، الطبعة الأولى، سنة 1429هـ-

\section{8}

علم المقاصد الشرعية، لنور الدين بن مختار الخادمي، مكتبة العبيكان، السعودية، الطبعة الأولى، سنة 1421هـ- 2001م. 
دعاوى حرية التعبير وأثرها فى زعزعة الاستقرار والثوابت

العين، للخليل بن أحمد الفراهيدي، تحقيق: الدكتور مهدي المخزومي والدكتور إبراهيم السامرائي، دار ومكتبة الهالال. فتح الباري شرح صحيح البخاري، لأحمد بن علي بن حجر العسقلاني، رقم كتبه وأبوابه وأحاديثه: محمد فؤاد عبد الباقي، قام بإخراجه وتصحيحه والإشراف على طبعه: محب الدين الخطيب، دار المعرفة، بيروت، سنة

الفرق بين النصيحة والتعيير، لزين الدين عبد الرحمن بن أحمد بن رجب، علق عليه وخرج أحاديثه: علي حسن علي عبد الحميد، دار عمان، عمان، الطبعة الثانية، سنة 409 1هـ- 1988م. الفقه الإسلامي وأدلثه (الشامل للأدلة الشرعية والآراء المذهبية وأهم النظريات الفقهية وتحقيق الأحاديث النبوية وتخريجها)، للدكثور وهبة الزحيلي، طبعة دار الفكر - سوريَّة - دمشق، الطبعة الرابعة. لحظ الألحاظ بذيل طبقات الحفاظ، لمحمد بن محمد الأصفوني، دار الكتب العلمية، بيروت، الطبعة الأولى، سنة 1419هـ- 1998م. لسان العرب، لمحمد بن مكرم ابن منظور، دار صادر، بيروت، الطبعة

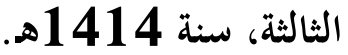
مرقاة المفاتيح شرح مشكاة المصابيح، للملا علي القاري، دار الفكر، بيروت، الطبعة الأولى، سنة 1422هـ- 2002م. مسند أحمد، تحقيق شعيب الأرنؤوط وآخرون، مؤسسة الرسالة، بيروت، لبنان، الطبعة الثانية، 1420هـ 
المصباح المنير في غريب الشرح الكبير، لأحمد بن محمد بن علي

$$
\text { الفيومي، المكتبة العلمية، بيروت. }
$$

معالم التنزيل في تفسير القرآن المسمى بتفسير البغوي، لمحمد الحسين

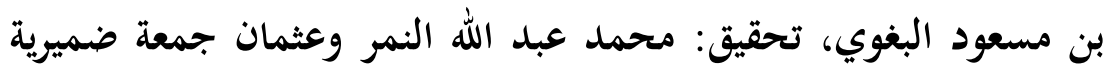
وسليمان بن مسلم الحرش، دار طيبة للنشر والتوزيع، الطبعة الرابعة، سنة

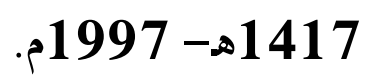

معالم السنن، لأبي سليمان حمد بن محمد الخطابي، المطبعة العلمية،

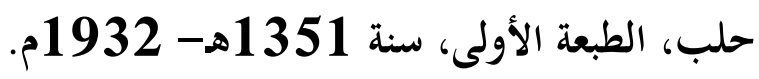
معجم الأدباء المسمى بإرشاد الأريب إلى معرفة الهئ الأديب، لياقوت

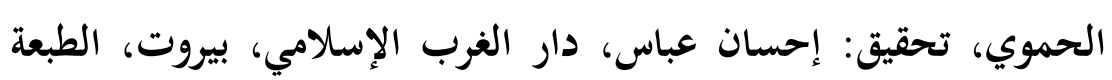

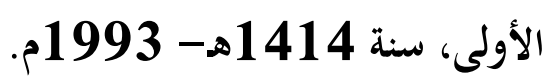
المعجم الفلسفي، مجمع اللغة العربية بالقاهرة، الهيئة العامة لشئون المطابع الأميرية، سنة 1403هـ- 1983م. المعجم الكبير، أعد هذا الجزء: عبد الصمد علي محروس وإقبال زكي الإني سليمان، ومراجعة الأستاذ الدكتور محمود علي مكي، مجمع اللغة العربية، القاهرة، الطبعة الأولى، سنة 1421هـ

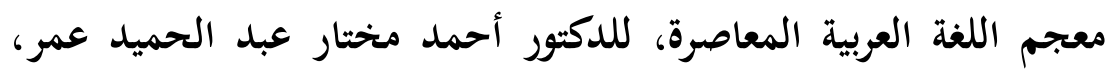

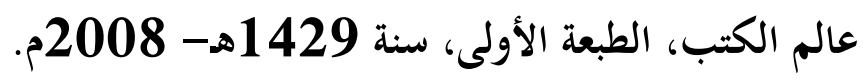

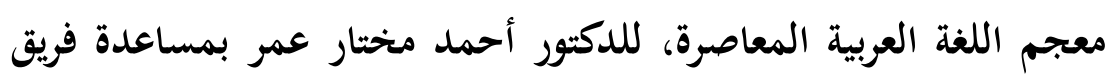
عمل، عالم الكتب، الطبعة الأولى، سنة 1429هـ - 2008م. 
دعاوى حرية التعبير وأثرها فى زعزعة الاستقرار والثوابت

معجم المؤلفين، لعمر رضا كحالة، مكتبة المثنى ودار إحياء التراث

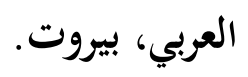

معجم لغة الفقهاء، لمحمد رواس قلعجي وحامد صادق قنيبي، دار النفائس للطباعة والنشر والتوزيع، الطبعة الثانية، سنة 1408هـ1988 معجم مقاييس اللغة، لأحمد بن فارس، تحقيق: عبد السلام محمد

$$
\text { هارون، دار الفكر، بيروت، سنة 1399هـ- مقاه } 1979 \text { 1م. }
$$

مقاصد الشريعة الإسلامية، لمحمد الطاهر بن محمد ابن عاشور، تحقيق: محمد الحبيب ابن الخوجة، وزارة الأوقاف والشئون الإسلامية، قطر، سنة

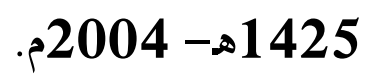
المنهاج شرح صحيح مسلم بن الحجاج، لمحيي الدين يحيى بن شرف النووي، دار إحياء التراث العربي، بيروت، الطبعة الثانية، سنة 1392هـ الموافقات، لإبراهيم بن موسى الشاطبي، تحقيق: أبو عبيدة مشهور بن حسن آل سلمان، دار عفان، الطبعة الأولى، سنة 1417هـ- 1997م. الموسوعة العربية العالمية، مؤسسة أعمال الموسوعة للنشر والتوزيع، الرياض، الطبعة الثانية، سنة 1419هـ- 1999م. الميسر في شرح مصابيح السنة، لفضل الله بن حسن بن حسين بن يوسف التوربشتي، تحقيق: الدكتور عبد الحميد هنداوي، مكتبة نزال مصطفى الباز، الطبعة الثانية، سنة 1429هـ- 2008م. 
دعاوى حرية التعبير وأثرها فى زعزعة الاستقرار والثوابت

نزهة الألباء في طبقات الأدباء، لعبد الرحمن بن محمد أبي البركات الأنباري، تحقيق: إبراهيم السامرائي، مكتبة المنار، الأردن، الطبعة الثالثة،

$$
\text { سنة 1405هـ- ندائ 1985م. }
$$

نفح الطيب من غصن الأندلس الرطيب، لأحمد بن محمد المقري التلمساني، تحقيق: الدكتور إحسان عباس، دار صادر، بيروت، سنة

\section{.1968}

نيل الأوطار، لمحمد بن علي بن محمد بن عبد الله الشوكاني اليمني، تحقيق: عصام الدين الصبابطي، دار الحديث، مصر، الطبعة الأولى، سنة 1413

وفيات الأعيان، لشمس الدين بن خلكان، تحقيق: إحسان عباس، دار صادر، بيروت، الطبعة الأولى، سنة 1900، 1971، 1994 1994م. يتيمة الدهر في محاسن أهل العصر، لعبد الملك بن محمد بن إسماعيل

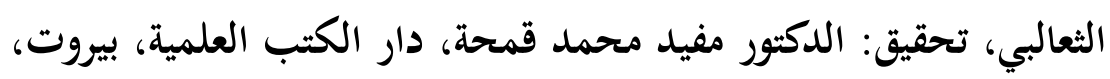
الطبعة الأولى، سنة 1403هـ- 1983م. 